\title{
Badania i wdrożenia
}

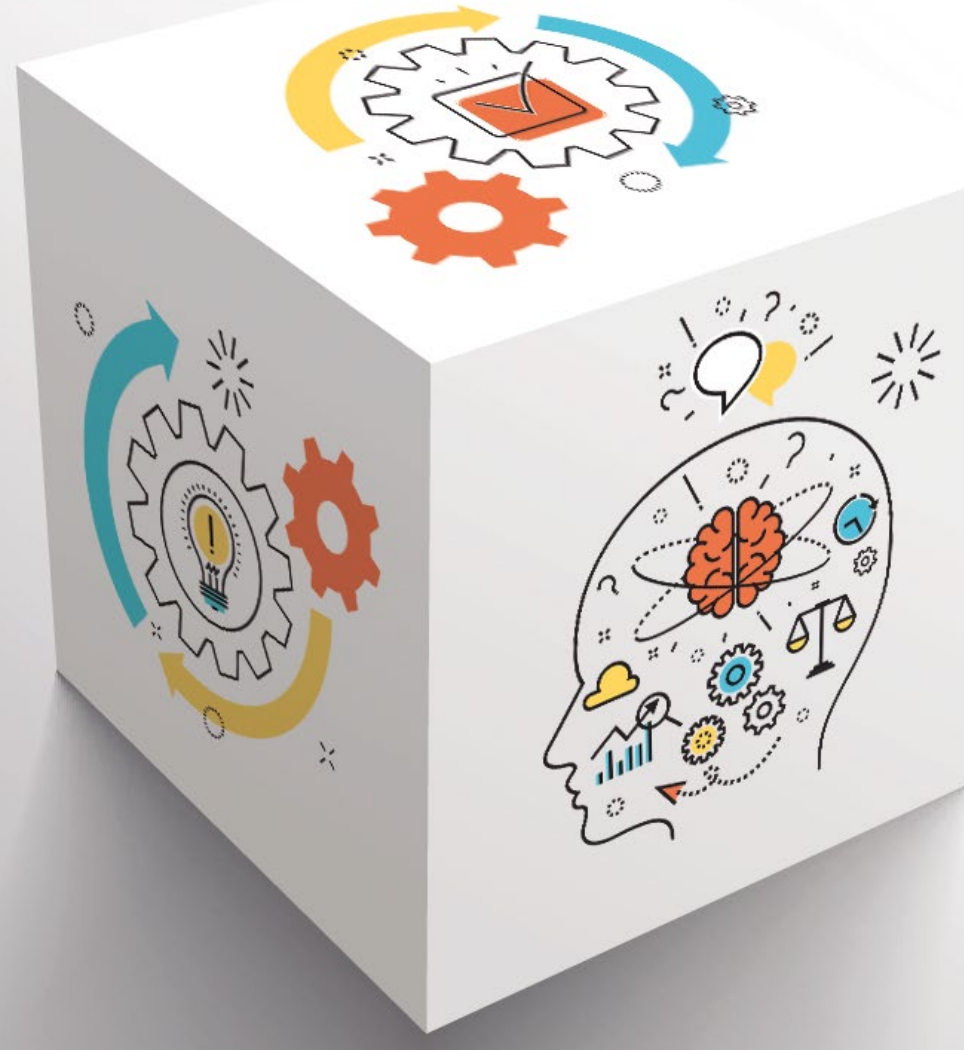

Interdyscyplinarność badań bezpieczeństwa

\author{
Jacek Zboina
}

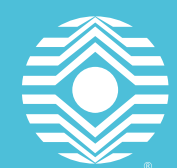

CNBOP-PIB 


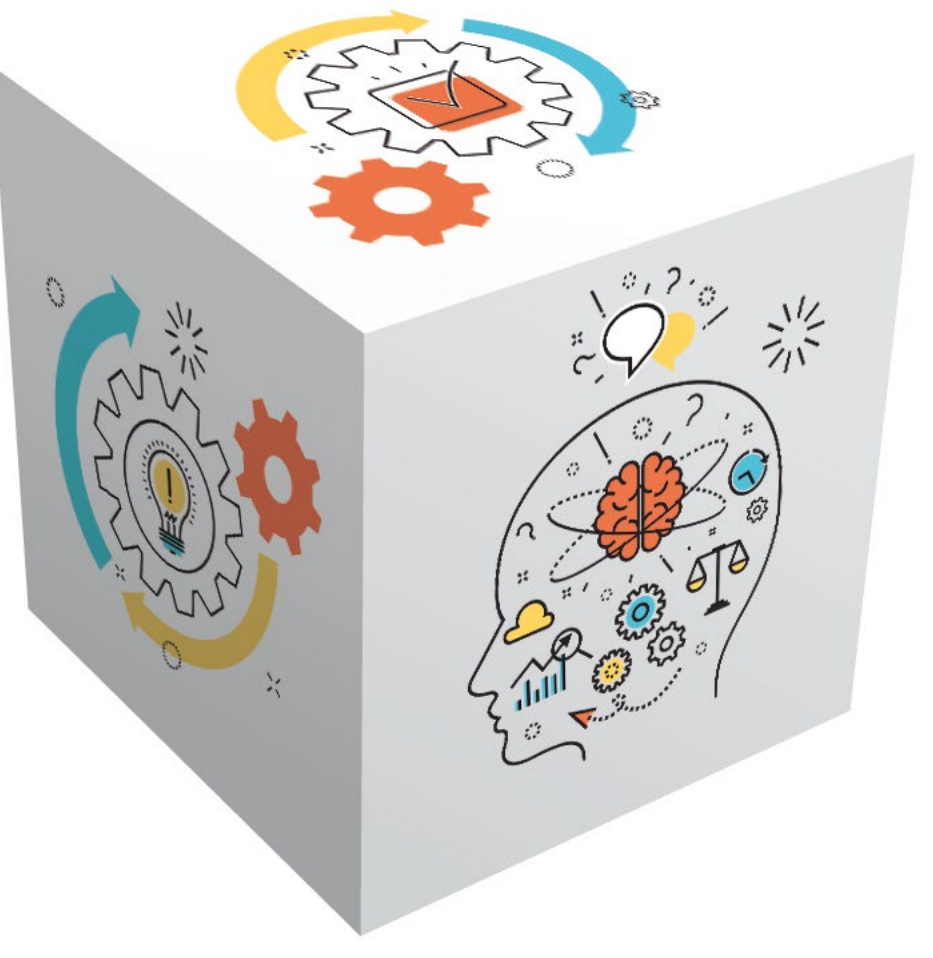




\section{Badania i wdrożenia}

\section{Interdyscyplinarność badań bezpieczeństwa}

\section{Jacek Zboina}

Publikacja opracowana w ramach projektu DOB-BIO9/26/04/2018

pt. Sterowanie autonomicznym dronem za pomoca gogli (monookularu)

Projekt w zakresie badań naukowych i prac rozwojowych

na rzecz obronności i bezpieczeństwa państwa, finansowany ze środków NCBR w ramach konkursu nr 9/2018, lata realizacji: 2018-2021

Projekt realizowany przez konsorcjum w składzie:

Simpro Sp. z. o. o.

Centrum Naukowo-Badawcze Ochrony Przeciwpożarowej im. Józefa Tuliszkowskiego - Państwowy Instytut Badawczy 


\section{Recenzja naukowa:}

dr hab. inż. Jarosław Prońko, prof. UJK w Kielcach

dr hab. inż. Andrzej Krzyszkowski

\section{Redakcja i korekta:}

Katarzyna Szulejewska

Elżbieta Muszyńska-Połeć

Aleksandra Grzęda

\section{Skład i projekt okładki:}

Małgorzata Żurniewicz-Turno

Grafika na okładce: Adobe Stock

Objętość: 5,3 ark. wyd.

ISBN 978-83-948534-8-8

DOI $10.17381 / 2020.2$

Publikacja jest dostępna na licencji Creative Commons-Uznanie autorstwa-Na tych samych warunkach 4.0 Międzynarodowe (CC BY-SA 4.0)

\section{Wydawca:}

Centrum Naukowo-Badawcze Ochrony Przeciwpożarowej im. Józefa Tuliszkowskiego

Państwowy Instytut Badawczy

ul. Nadwiślańska 213

05-420 Józefów k. Otwocka

www.cnbop.pl 


\section{Spis treści}

Definicje i skróty

6

Wstęp 16

I. Inżynieria bezpieczeństwa pożarowego 20

1.1. Rozumienie i znaczenie $\quad 20$

1.2. Perspektywy rozwoju i potrzeby 27

1.3. Wnioski 32

II. Wdrażanie nowych technologii i rozwiazzań 35

2.1. Podstawy formalne 35

2.2. Zaufanie do wyrobów i rozwiązań $\quad 39$

2.3. Ekosystem dla innowacji $\quad 41$

2.4. Współpraca: Oferta, Komunikacja, Emocje, Negocjacje, 43 Ludzie, Liderzy, Przywództwo, Technologia, Innowacje

2.5. Wnioski 58

III. Badania i wdrożenia 61

3.1. Badania naukowe 61

3.2. Badania bezpieczeństwa pożarowego 63

3.3. Współpraca nauka - biznes 65

3.4. Od badania do wdrożenia 72

3.5. Wnioski 74

$\begin{array}{ll}\text { Podsumowanie } & 75\end{array}$

$\begin{array}{ll}\text { Bibliografia } & 77\end{array}$

$\begin{array}{ll}\text { Nota o autorze } & 84\end{array}$

$\begin{array}{ll}\text { Załączniki } & 85\end{array}$

1. Zintegrowany System Kwalifikacji w ochronie przeciwpożarowej

2. Podstawowe informacje o projekcie nr DOB-BIO9/26/04/2018 Sterowanie autonomicznym dronem za pomoca gogli (monookularu) 


\section{Definicje i skróty}

Ważne definicje pojęć stosowanych lub przywoływanych w publikacji oraz wyjaśnienia używanych skrótów przedstawiono poniżej w porządku alfabetycznym. Przyjęto zasadę przywołania definicji uznanych przez autora za najbardziej właściwe, a także tych określonych w obowiązującym prawodawstwie. W razie ich braku, niejednoznaczności czy niezrozumiałości cytowane są definicje zaczerpnięte ze źródeł, takich jak: książki, słowniki, normy, wytyczne, standardy itp. W uzasadnionych sytuacjach autor przywołuje więcej niż jedną definicję z podaniem źródeł. Gdy dane pojęcie opatrzone jest kilkoma definicjami, są one odpowiednio numerowane.

BSP - bezzałogowy statek powietrzny

CNBOP-PIB - Centrum Naukowo-Badawcze Ochrony Przeciwpożarowej-Państwowy Instytut Badawczy im. Józefa Tuliszkowskiego

KP/KM PSP - Komenda Powiatowa (Komendant Powiatowy)/Komenda Miejska (Komendant Miejski) Państwowej Straży Pożarnej

KSP - kaseta straży pożarnej

KSRG - krajowy system ratowniczo-gaśniczy

PSP - Państwowa Straż Pożarna

RP - Rzeczpospolita Polska

SGSP - Szkoła Główna Służby Pożarniczej

ZSK - Zintegrowany System Kwalifikacji

\section{Bezpieczeństwo}

1. Wolność od zagrożeń, strachu lub ataku.

J. Stańczyk, Współczesne pojmowanie bezpieczeństwa, Instytut Studiów Politycznych PAN, Warszawa 1996, s. 16.

2. Jest nie tyle określonym stanem rzeczy, ile ciągłym procesem społecznym, w którego ramach podmioty działające starają się doskonalić mechanizmy zapewniające im poczucie bezpieczeństwa.

J. Stańczyk, Współczesne pojmowanie bezpieczeństwa, Instytut Studiów Politycznych PAN, Warszawa 1996, s. 18. 


\section{Badania i wdrożenia | Definicje i skróty}

3. Pochodzi od łacińskiego słowa securitas (bezpieczeństwo, pewność), a także od sine cura (bez troski); rozumiane jest jako pewność, spokój, przewidywalność, zaspokajanie podstawowych potrzeb.

A. Mizerski, Definicje przygotowane przez zespół zadaniowy do spraw problematyki zakresów dyscyplin naukowych, określonych $w$ krajowym porzadku prawnym, Rada Naukowo-Techniczna przy Ministrze Spraw Wewnętrznych, Warszawa 2013.

4. Bezpieczeństwo definiuje się jako proces lub stan zapewniający funkcjonowanie państwa w podstawowych dziedzinach, umożliwiających jego przetrwanie, rozwój, swobodę realizacji interesów narodowych w określonym środowisku bezpieczeństwa poprzez podejmowanie wyzwań, wykorzystywanie szans, redukowanie ryzyka oraz przeciwdziałanie zagrożeniu dla jego interesów (zob. Stownik terminów z zakresu bezpieczeństwa narodowego, AON, Warszawa 2009, s. 13-16). Bezpieczeństwo oznacza nie tylko stan braku zagrożenia, pewności i spokoju lub poczucia wolności od zagrożeń, lecz także proces, który ulega przekształceniom odpowiednio do zmian w otoczeniu podmiotu bezpieczeństwa. Postrzegając bezpieczeństwo jako proces, powinniśmy mieć świadomość, że zmienne w tym procesie będą za każdym razem kreowały inny poziom bezpieczeństwa. Proces bezpieczeństwa oznacza również pewien cykl, w którym po wystąpieniu określonych uwarunkowań ewoluuje bezpieczeństwo, posiadające wartość zmienną w każdej fazie swego rozwoju. Zakończenie danego procesu może dać nam wynik, który określimy stanem bezpieczeństwa w pewnych uwarunkowaniach: przestrzennych, czasowych, materiałowych, decyzyjnych oraz przy danej skali zagrożenia. Stan bezpieczeństwa wynika z połączenia jego trzech cech: szans, wyzwań i zagrożeń oraz identyfikacji treści relacji pomiędzy nimi.

Czupryński A., Bezpieczeństwo w ujęciu teoretycznym, w: Bezpieczeństwo, teoria, badania, praktyka, A. Czupryński, B. Wiśniewski, J. Zboina (red.), Wydawnictwo CNBOP-PIB, Józefów 2015, s. 12.

\section{Bezpieczeństwo publiczne}

1. Ogół warunków i instytucji chroniących życie, zdrowie i mienie obywateli oraz majątek ogólnonarodowy, ustrój i suwerenność państwa przed zjawiskami groźnymi dla ładu prawnego.

Bezpieczeństwo publiczne, w: Encyklopedia PWN, 2012.

2. Stan faktyczny wewnątrz państwa, który umożliwia - bez narażenia na szkody (wywołane zarówno zachowaniem ludzi, jak i działaniem sił natury, techniki itp.) 
- normalne funkcjonowanie organizacji państwowej i realizację jej interesów, zachowanie życia, zdrowia i mienia jednostek żyjących w tej organizacji (...) oraz korzystanie przez te jednostki z praw i swobód zagwarantowanych konstytucją i innymi przepisami prawa.

J. Zaborowski, Administracyjno-prawne ujęcie pojęć „,bezpieczeństwo publiczne” i porządek publiczny” (niektóre uwagi w świetle unormowań prawnych 1983-1984), „Zeszyty Naukowe ASW" 1985, Nr 41, s. 129.

\section{Bezpieczeństwo pożarowe}

1. Stan eliminujący zagrożenie dla życia lub zdrowia ludzi, zapewniony przez funkcjonowanie systemu norm prawnych i technicznych środków zabezpieczenia przeciwpożarowego oraz prowadzonych działań zapobiegawczych przed pożarem.

Rozporządzenie MSWiA z dnia 3 listopada 1992 r. w sprawie ochrony przeciwpożarowej budynków, innych obiektów budowlanych i terenów (Dz. U. z 1992 Nr 92, poz. 460), akt uchylony.

2. Stan, sytuacja będące rezultatem skuteczności (funkcjonowania) systemu ochrony przeciwpożarowej w odniesieniu do pożarów.

J. Zboina, Doskonalenie ochrony przeciwpożarowej jako warunek niezbędny zapewnienia bezpieczeństwa wewnętrznego Rzeczypospolitej Polskiej, rozprawa doktorska, AMW, Gdynia 2014.

Bezpieczeństwo wewnętrzne - określony stan struktur społecznych, politycznych i ekonomicznych wewnątrz państwa i takie ich kształtowanie, aby zapewniały poczucie pewności jego obywatelom oraz stwarzały odpowiednie warunki do realizacji aspiracji tego państwa.

W. Fehler, O pojęciu bezpieczeństwa państwa, w: Bezpieczeństwo państw i narodów w procesie integracji europejskiej, W. Śmiałek, J. Tymanowski (red.), Wydawnictwo Adam Marszałek, Toruń 2002, s. 72.

Czas dojazdu do miejsca zdarzenia - czas, który upłynął od momentu zaalarmowania zastępów do momentu przyjazdu na miejsce zdarzenia.

Zasady organizacji ratownictwa chemicznego i ekologicznego $w$ krajowym systemie ratowniczo-gaśniczym, KG PSP, Warszawa 2012.

\section{Czynności ratownicze:}

podstawowe - czynności wykonywane w poszczególnych dziedzinach ratownictwa przez wszystkich ratowników podmiotów KSRG, 
specjalistyczne - czynności wykonywane z użyciem sprzętu specjalistycznego przez odpowiednio przeszkolonych ratowników podmiotów KSRG.

§ 2 rozporządzenia Ministra Spraw Wewnętrznych i Administracji z dnia 3 lipca 2017 r. w sprawie szczegółowej organizacji krajowego systemu ratowniczo-gaśniczego (Dz. U. poz. 1319).

\section{Doskonalenie systemu}

Pojęcie ciągłego doskonalenia zostało zapożyczone z tzw. pętli Deminga (cykl PDCA: Plan - Do - Check - Act), która obejmuje kroki doskonalenia: planowanie, wykonywanie, sprawdzanie oraz poprawianie (podejmowanie działań), które realizowane są nieustannie, co prowadzi do podnoszenia skuteczności, efektywności lub jakości w badanym obszarze.

S. Wawak, O Zarzadzaniu, http://wawak.pl/pl/content/ciagle-doskonalenie [dostęp: 12.11.2013].

\section{Dzialania ratownicze}

1. Wszystkie czynności podjęte w celu ochrony życia, zdrowia, mienia lub środowiska, a także likwidacji przyczyn powstania pożaru lub każdego innego miejscowego zagrożenia.

Art. 2. ustawy z dnia 24 sierpnia 1991 r. o ochronie przeciwpożarowej (tekst jedn.: Dz. U. 2020 poz. 961).

2. Zespół przedsięwzięć planistyczno-organizacyjnych oraz podejmowanie działań, technik i środków ratowniczych stosownie do określonego zdarzenia, celem ratowania ludzi, zwierząt, mienia, środowiska i zgaszenia pożaru.

P. Bielicki, Dowodzenie gaszeniem pożarów, ZW ZOSP RP, Gdańsk 2009.

Działania operacyjne - polegają na współdziałaniu straży pożarnej, policji pogotowia ratunkowego, gazowego itp. z osobami zarządzającymi danym budynkiem i komercyjnymi służbami ochrony, podejmowane w celu zmniejszenia lub likwidacji destrukcyjnych skutków narażających zdrowie, życie czy inne dobro osób będących w strefie zagrożenia.

S.E. Dworecki, Logistyka w zarządzaniu bezpieczeństwem cywilnym (Wybrane zagadnienia), SGSP, Warszawa 2012, s. 31.

Ewakuacja ludności - zorganizowane jej przemieszczanie z rejonów (stref) zagrożenia życia lub zdrowia do obszarów (miejsc) bezpiecznych w celu ochrony lub udzielenia pomocy.

Stownik terminów z zakresu bezpieczeństwa narodowego, AON, Warszawa 2002. 
Gotowość operacyjna - zdolność do realizowania czynności ratowniczych w poszczególnych dziedzinach ratownictwa.

$\S 1$ rozporządzenia MSWiA z dnia 18 lutego 2011 r. w sprawie szczegółowych zasad organizacji krajowego systemu ratowniczo-gaśniczego (Dz. U. Nr 46, poz. 239, nie obowiązuje).

Innowacja - wprowadzenie do praktyki w przedsiębiorstwie, organizacji, instytucie itp. nowego lub znacząco ulepszonego rozwiązania w odniesieniu do produktu (towaru lub usługi), procesu, marketingu lub organizacji. Istotą innowacji jest właściwe wdrożenie nowości do praktyki.

R. Kasprzak, Fundusze Unijne, szansa dla małych i średnich przedsiębiorstw, Wydawnictwo Helion, Gliwice 2009, s. 45.

Inżynieria bezpieczeństwa - odnosi się do planowania, projektowania, budowania, organizowania i funkcjonowania systemów związanych z koniecznością przeciwdziałania zagrożeniom ogółu ludzkości, środowiska naturalnego oraz dóbr cywilizacyjnych.

A. Mizerski, dz. cyt.

Inżynieria środowiska, górnictwo i energetyka - inżynieria środowiska obejmuje przedsięwzięcia inżynierskie ukierunkowane na zachowanie stanu równowagi środowiska przyrodniczego oraz umożliwienie jego zdolności do samoregeneracji i samooczyszczania oraz odtworzenia walorów przyrodniczych. Inżynieria środowiska dostarcza naukowych podstaw racjonalnego gospodarowania zasobami przyrody oraz prognozowania, oceny, zapobiegania i naprawy negatywnych skutków niszczenia tych zasobów. Ważnym celem inżynierii środowiska jest edukowanie społeczeństwa w zakresie podejmowanych działań technicznych.

D. Lipińska, Podstawy inżynierii środowiska, Wydawnictwo Uniwersytetu Łódzkiego, Łódź 2016.

Norma - dokument przyjęty na zasadzie konsensu, ustalający zasady lub charakterystyki odnoszące się do różnych rodzajów działalności lub ich wyników i zmierzający do uporządkowania w określonym zakresie. Normy są oparte na osiągnięciach zarówno nauki, techniki, jak i praktyki oraz mają na celu uzyskanie optymalnych korzyści społecznych.

Strona internetowa Biblioteki Głównej AGH, www.bg.agh.edu.pl [dostęp: 13.02.2020].

Polska Norma - krajowa, przyjęta w drodze konsensu i zatwierdzona przez krajową jednostkę normalizacyjną, powszechnie dostępna, stosowana dobrowolnie, oznaczona - 
na zasadzie wyłączności - symbolem PN. Może być także wprowadzeniem normy europejskiej lub międzynarodowej. Wprowadzenie to może nastąpić w języku oryginału. Za tworzenie i treść Polskich Norm są odpowiedzialne Organy Techniczne działające przy PKN - ciała złożonego z przedstawicieli podmiotów gospodarczych, administracji rządowej, instytucji, stowarzyszeń, jednostek badawczych, organizacji zawodowych i konsumenckich, zainteresowanych udziałem w normalizacji. Działalność KT wynika z podstawowej zasady normalizacji dobrowolnej - normy tworzą zainteresowani na własne potrzeby i z własnych środków.

PKN nie ma wpływu na treść norm, nadzoruje jedynie zgodność procesów ich opracowywania z przepisami wewnętrznymi PKN. Zatwierdzenie projektu przez PKN jest formalnym stwierdzeniem tej zgodności i nadania projektowi statusu normy krajowej (Polskiej Normy).

Strona internetowa Polskiego Komitetu Normalizacyjnego, zakładka Informacje podstawowe o PN, www.pkn.pl/informacje-podstawowe-o-pn [dostęp 13.02.2020].

Norma Europejska $\mathbf{E N}$ - wspólna nazwa dokumentów normalizacyjnych, zatwierdzanych przez Europejski Komitet Normalizacyjny (CEN), Europejski Komitet Normalizacyjny do spraw Elektrotechniki (CENELEC) i Europejski Instytut Normalizacyjny do spraw Telekomunikacji (ETSI). Są to: zatwierdzane przez CEN i CENELEC właściwe normy europejskie, tj. Normy Europejskie (EN), Normy Europejskie Wstępne (ENV) i Dokumenty Harmonizacyjne (HD), a także (zatwierdzane przez ETSI) Europejskie Normy Telekomunikacyjne (ETS). Normy europejskie są jednym z ważniejszych czynników uczestniczących w tworzeniu tzw. europejskiej strefy ekonomicznej i wraz z przepisami technicznymi stanowią system prawa technicznego niezbędny do funkcjonowania UE.

Internetowa encyklopedia PWN, www.encyklopedia.pwn.pl [dostęp 13.02.2020].

Normy EN zharmonizowane - specyfikacje techniczne przygotowane przez komitety techniczne europejskich organizacji normalizacyjnych, mające formalne zlecenie Komisji Europejskiej, przyjęte na podstawie pomyślnie przeprowadzonego głosowania formalnego wszystkich krajowych organizacji normalizacyjnych państw członkowskich UE i EFTA i opublikowane w Dzienniku Urzędowym Wspólnot Europejskich. Normy zostały opracowane na zlecenie (zwane mandatem) Komisji Europejskiej przez Europejski Komitet Normalizacyjny (CEN), Europejski Komitet Normalizacji Elektrotechnicznej (CENELEC), Europejski Instytut Norm Telekomunikacyjnych (ETSI).

Strona internetowa Ministerstwa Gospodarki, www.mg.gov.pl; strona internetowa Polskiego Komitetu Normalizacyjnego, zakładka Normy Zharmonizowane, www.pkn.pl/normy-zharmonizowane, Internetowa encyklopedia PWN, www.encyklopedia.pwn.pl [dostęp 13.02.2020]. 
Norma Międzynarodowa ISO - norma międzynarodowa, zatwierdzana przez Międzynarodową Organizację Normalizacyjną (norma ISO) i Międzynarodową Komisję Elektrotechniczną (norma IEC); jej zadaniem jest likwidowanie barier w handlu międzynarodowym oraz we współpracy naukowej i technicznej. Internetowa encyklopedia PWN, www.encyklopedia.pwn.pl [dostęp: 13.02.2020].

\section{Ocena zgodności}

1. Określana jest m.in. jako wskazanie, że wyspecyfikowane wymagania dotyczące wyrobu, procesu, systemu, osoby lub jednostki zostały spełnione.

Norma EN ISO/IEC 17000:2004 Ocena zgodności. Terminologia i zasady ogólne.

2. Definiowana jest również bardzo często jako badania i certyfikacja. Na ocenę zgodności składają się:

- przepisy określające zasadnicze i szczegółowe wymagania dotyczące wyrobów,

- przepisy oraz normy określające działanie podmiotów uczestniczących w procesie oceny zgodności.

Art. 3 ustawy z dnia 30 sierpnia 2002 r. o systemie oceny zgodności (tekst jedn.: Dz. U. 2019 poz. 155).

W ocenie zgodności wyrobów wyróżniamy najczęściej badania, sprawdzenie zgodności z wymaganiami i certyfikację. Pozytywny wynik przeprowadzonej oceny zgodności wyrobu z wymaganiami stanowi podstawę do wydania producentowi lub jego upoważnionemu przedstawicielowi dokumentu potwierdzającego zgodność, tj. najczęściej certyfikatu zgodności, świadectwa, atestu itp.

Ochrona przeciwpożarowa - polega na realizacji przedsięwzięć mających na celu ochronę życia, zdrowia i mienia lub środowiska przed pożarem, katastrofą lub innym miejscowym zagrożeniem poprzez zapobieganie powstaniu i rozprzestrzenianiu się pożarów, zapewnienie niezbędnych zasobów do ich zwalczania i prowadzenie działań ratowniczych.

Art. 1 ustawy z dn. 24 sierpnia 1991 r. o ochronie przeciwpożarowej (tekst jedn.: Dz. U. 2020 poz. 961).

Państwowa Straż Pożarna - zawodowa, umundurowana i wyposażona w specjalistyczny sprzęt formacja, przeznaczona do walki z pożarami, klęskami żywiołowymi i innymi miejscowymi zagrożeniami.

Ustawa z dnia 24 sierpnia 1991 r. o Państwowej Straży Pożarnej (tekst jedn.: Dz. U. 2020 poz. 1123). 
Pożar - niekontrolowany proces palenia przebiegający w miejscu do tego nieprzeznaczonym. Dla potrzeb statystycznych klasyfikuje się pożary jako małe, średnie, duże i bardzo duże. Podstawą podziału jest powierzchnia lub kubatura pożaru, a w wypadku gdy obie wielkości są trudne do określenia - liczba prądów gaśniczych wprowadzonych do akcji gaszenia pożaru.

Inny podział uwzględnia miejsce, w którym pożar przebiega, jego rozwój i zewnętrzne objawy palenia. Wówczas wyróżnia się pożary: wewnętrzne, zewnętrzne, blokowe i przestrzenne. Charakterystyczne cechy pożaru to: możliwość występowania wysokiej temperatury, wydzielanie dużych ilości produktów spalania, możliwość rozprzestrzeniania.

P. Bielicki, Podstawy taktyki gaszenia pożarów, SAPSP, Kraków 1996; M. Pofit-Szczepańska, Wybrane zagadnienia z chemii ogólnej, fizykochemii spalania i rozwoju pożarów, SAPSP, Kraków 1994; J. Wolanin, Wybrane zagadnienia z podstaw rozwoju pożarów wewnętrznych, KG PSP, Warszawa 1985.

Ratownictwo - ogół środków, przedsięwzięć organizacyjnych i metod ratowania życia ludzi oraz niesienia pomocy w warunkach zagrożenia (np. w czasie sztormu na morzu, zagubienia w górach, wypadku w kopalni), a także służących, m.in. ratowaniu lub zabezpieczaniu sprzętu, pomieszczeń.

Ratownictwo, w: Encyklopedia PWN, 2012.

Ratownik - osoba odpowiednio przeszkolona, przygotowana i wyposażona, zobowiązana do niesienia pomocy.

P. Bielicki, Podstawy taktyki gaszenia pożarów, SAPSP, Kraków 1996; Tenże, Taktyka działań gaśniczych dla stuchaczy kursu kwalifikacyjnego szeregowych Państwowej Straży Pożarnej, KGPSP, Warszawa 2004.

Strefa pożarowa - przestrzeń wraz z zabudową odizolowana od innych budynków lub innych części budynku elementami oddzielenia przeciwpożarowego (ściany, stropy i drzwi o określonych klasach nośności, szczelności i izolacyjności ogniowej) lub też pasami wolnego terenu o szerokości nie mniejszej niż określone przepisami dopuszczalne odległości od innych budynków.

Ł. Osikowicz, K. Szczerba, Zasady bezpiecznej eksploatacji obiektów, Wydawnictwo CNBOP-PIB, Józefów 2012.

Symulacja - jest to manipulowanie modelem w taki sposób, że działa on w zmienionej skali w czasie i/lub w czasoprzestrzeni, umożliwiając nam uchwy- 
cenie oddziaływań i zachowań, które w innym przypadku byłyby nieuchwytne, np. z tytułu ich czasoprzestrzennego oddalenia.

C. Cempel, Teoria i inżynieria systemów - zasady i zastosowania myślenia systemowego, Wydawnictwo Naukowe ITE PIB, Poznań 2008, s. 88.

System - byt, będący zorganizowanym zbiorem elementów z określonymi właściwościami i relacjami, stanowiący jedną celowościową całość.

C. Cempel, Teoria i inżynieria..., dz. cyt., s. 259.

Technicznie środki zabezpieczeń przeciwpożarowych - urządzenia, sprzęt, instalacje i rozwiązania budowlane służące zapobieganiu powstawaniu i rozprzestrzenianiu się pożarów.

§ 2.1. rozporządzenia MSWiA z dnia 7 czerwca $2010 \mathrm{r}$. w sprawie ochrony przeciwpożarowej budynków, innych obiektów budowlanych i terenów (Dz. U. Nr 109, poz. 719).

Wymagania podstawowe (zasadnicze) - Wymagania podstawowe dotyczą w szczególności bezpieczeństwa użytkowania, stosowania.

Większość Dyrektyw nowego podejścia określa wymagania związane z bezpieczeństwem użytkowania wyrobów, czyli z eliminacją zagrożeń dla życia i zdrowia ludzi i zwierząt, mienia i środowiska. Niektóre z nich uwzględniają inne aspekty, np. oszczędność energii, dokładność metrologiczną wskazań instrumentów pomiarowych, bezpieczeństwo transportu niektórych urządzeń. Zgodnie z przyjętą koncepcją - uwarunkowaną powszechnością zastosowania Dyrektyw... - ujmowane w nich zagadnienia są formułowane w sposób ogólny, tak aby obejmowały możliwie wszystkie przypadki dotyczące ich przedmiotu. Postanowienia Dyrektyw... wskazują przede wszystkim cele, jakie należy osiągnąć, oraz kierunki działań prowadzących do ich osiągnięcia. Pozostawiają użytkownikowi swobodę w wyborze sposobów do tego prowadzących. Nie narzucają zatem jednolitych rozwiązań, a w zakresie osiągania wytyczonych celów wymagają aktywności i inwencji podmiotów, których dotyczą. Dyrektywy nowego podejścia są dyrektywami całkowitej harmonizacji, a ich postanowienia zastępują wszystkie odpowiednie przepisy krajowe, które powinny być uchylone. Strona internetowa Ministerstwa Gospodarki, www.mg.gov.pl/Wspieranie+przedsiebiorczosci/Bezpieczenstwo+produktow+i+uslug/Ocena+zgodnosci/Dyrektywy+Nowego+Podejscia [dostęp: 30.05.2019].

Wymagania dodatkowe - to wymagania krajowe stawiane wybranym wyrobom stosowanym w ochronie przeciwpożarowej i służącym ochronie zdrowia i życia 
ratowanych i ratowników oraz mienia (określone w rozporządzaniu MSWiA, jako wymagania techniczno-użytkowe).

Rozporządzenie z dnia 27 kwietnia 2010 zmieniające rozporządzenie Ministra Spraw Wewnętrznych i Administracji z dnia 20 czerwca 2007 r. w sprawie wykazu wyrobów służących zapewnieniu bezpieczeństwa publicznego lub ochronie zdrowia i życia oraz mienia, a także zasad wydawania dopuszczenia tych wyrobów do użytkowania (Dz. U. Nr 85, poz. 553).

Zagrożenie - to pewien stan psychiczny lub świadomościowy wywołany postrzeganiem zjawisk, które subiektywnie ocenia się jako niekorzystne lub niebezpieczne. To także czynniki obiektywne powodujące stany niepewności i obaw.

S. Korycki, System bezpieczeństwa Polski, AON, Warszawa 1994, s. 54. 


\section{Wstęp}

$\mathrm{P}$

rzedmiotowa publikacja to kolejna próba ${ }^{1}$ przybliżenia - w mojej ocenie - najważniejszych, aktualnych i użytecznych zagadnień dotyczących badań i działań na rzecz bezpieczeństwa pożarowego w praktyce wdrażania nowych technologii i rozwiązań. Postanowiłem jednak tym razem nieco inaczej niż dotychczas podejść redakcyjnie do prezentacji zagadnień. Wyniki mojej pracy dostępne są poniżej.

O interdyscyplinarnym charakterze badań nad bezpieczeństwem przekonałem się po raz pierwszy, kiedy wiele lat temu, jako młody inżynier, myśląc o rozpoczęciu pracy i badań naukowych, trafiłem do życzliwego pana profesora w Instytucie Podstawowych Problemów Techniki Polskiej Akademii Nauk. Umówiliśmy się na spotkanie, którego celem było określenie klasyfikacji badań dotyczących bezpieczeństwa pożarowego, które zamierzałem prowadzić. Po kilku godzinach rozmów, konkludując, pan profesor zachęcił mnie, bym nie poddawał się w swoich dążeniach i planach badań - zagadnienia nie tylko są ciekawe, ale i ważne. Stwierdził jednocześnie, iż trudno będzie ochronę przeciwpożarową zakwalifikować do konkretnej dziedziny i dyscypliny naukowej², dodając z uśmiechem: „Dziwna ta Pana ochrona przeciwpożarowa. Ani to matematyka, ani chemia (mimo iż inżynieria) ${ }^{3}$, ale proszę być

1 Dotychczas tematyka ta była prezentowana w różnym kontekście przez autora między innymi w publikacjach:

J. Zboina, P. Gancarczyk, Certyfikacja usług w ochronie przeciwpożarowej w ujęciu praktycznym i teoretycznym, Wydawnictwo CNBOP-PIB, Józefów 2016.

J. Zboina, Bezpieczeństwo pożarowe - właściwości stosowanych wyrobów i jakości świadczonych ustug, w: Administracja Bezpieczeństwa. Wybrane problemy - tom IV, B. Wiśniewski, A. Babiński, A. Osierda, P. Kobes (red.), Wyższa Szkoła w Bielsku-Białej, Bielsko-Biała 2017.

J. Zboina, P. Wojtaszewski, Wytyczne i certyfikacja rozwiazań organizacyjnych i technicznych obiektów zabytkowych, w: Wybrane zagadnienia bezpieczeństwa pożarowego obiektów zabytkowych. Wyniki badań i rekomendacje, J. Zboina (red.), Wydawnictwo CNBOP-PIB, Józefów 2016.

J. Zboina, Conformity Assessment in Fire Protection, w: Legal Context in the Chosen Order and Security Area, P. Kobes, G. Sander (red.), Verlag Dr Kovač, Hamburg 2016.

J. Zboina, Wymagania i system dopuszczeń sprzętu i wyposażenia, w: Logistyka $w$ dwudziestoleciu Państwowej Straży Pożarnej, M. Kowalski (red.), KG PSP, Warszawa 2015.

J. Zboina, Zapewnienie bezpieczeństwa powszechnego a właściwości stosowanych wyrobów i jakość świadczonych usług w zakresie ochrony przeciwpożarowej, w: Współczesność oraz perspektywy Krajowego Systemu Ratowniczo-Gaśniczego - tom II, B. Kogut (red.), Szkoła Aspirantów PSP w Krakowie, Kraków 2015.

J. Zboina, Wybrane zagadnienia bezpieczeństwa pożarowego obiektów zabytkowych. Wyniki badań i rekomendacje, Wydawnictwo CNBOP-PIB, Józefów 2016.

J. Zboina, Bezpieczeństwo pożarowe - rozważania na gruncie nauki i praktyki, Wydawnictwo CNBOP-PIB, Józefów 2016.

2 Systematyka dziedzin i dyscyplin naukowych w Polsce ulegała zmianie na przestrzeni ostatnich lat, aktualnie wyróżnia się odpowiednio obszary wiedzy, dziedziny nauki, dyscypliny naukowe.

3 Dopiero wiele lat później stało się dla mnie oczywiste, iż przedsięwzięcia ochrony przeciwpożarowej przynajmniej w części zawierają się w zakresie inżynierii środowiska, której praktyczna definicja została przedstawiona między innymi przez D. Lipińską w publikacji Podstawy inżynierii środowiska. Definicja ta przywołana została w rozdziale pierwszym niniejszej publikacji. 


\section{Badania i wdrożenia | Wstęp}

wytrwałym w swoich badaniach”. Na drodze zawodowej spotykamy osoby, które wywierają istotny wpływ na osiągane później przez nas cele i wyniki. Przywołany powyżej pan profesor - mimo iż spotkaliśmy się tylko raz - był jedną z tych ważnych postaci na mojej dalszej drodze badań nad bezpieczeństwem. Tak jak sugerował, nie poddawałem się - szukałem nowych szans, możliwości i sposobu na to, aby prowadzić badania naukowe nad bezpieczeństwem pożarowym. Na mojej drodze pojawili się inni życzliwi mi ludzie, którzy wskazali szanse i możliwości, pomogli, a także dodali otuchy. Ale wciąż wątpliwości było dużo. Praca zawodowa związana bezpośrednio z nowymi technologiami i rozwiązaniami technicznymi inspirowała mnie i motywowała do podejmowania kolejnych prób inicjowania badań naukowych i wykorzystywania ich w praktyce. Prace badawczo-rozwojowe, w których uczestniczyłem i którymi kierowałem, dostarczały natomiast dowodów na to, iż badania naukowe nie tylko mogą być użyteczne dla praktyki ochrony przeciwpożarowej, ale również dawać nowe możliwości i wskazywać kierunki działań i rozwoju. Samodzielnie prowadzone badania naukowe w zakresie nauk o bezpieczeństwie rozpocząłem dzięki życzliwości, radzie i pomocy kolejnych serdecznych osób. Byli wśród nich profesorowie, generałowie i oficerowie wojska polskiego, straży pożarnej, policji, a także praktycy i specjaliści różnych dziedzin. Ci ludzie nauki, środowisk służbowych, biznesu, a także specjaliści pomogli mi bardzo w pierwszych i kolejnych krokach badań nad bezpieczeństwem pożarowym. Przygotowanie tej publikacji uświadomiło mi kilka ważnych etapów moich dotychczasowych badań, a przede wszystkim postawiło przed oczy ważnych ludzi, którzy w dotychczasowej drodze wspierali mnie, dzielili się ze mną swoją wiedzą, doświadczeniem i wątpliwościami, stwarzali możliwości, pozwalali mi działać, motywowali i dodawali otuchy, wskazywali zagrożenia, szanse i wyzwania. Myślę, że to właściwe miejsce, aby im za to podziękować. Jednak wymienienie ich wszystkich, z uwzględnieniem odpowiedniej kolejności, okazało się wielkim wyzwaniem. Stąd decyzja, aby sformułować ogólne podziękowania dla wszystkich, którzy poprzez swoją pomoc, życzliwość i zaangażowanie przyczynili się do tego, iż mogłem dotychczas prowadzić interdyscyplinarne badania nad bezpieczeństwem. Mam nadzieję przynajmniej niektórym z nich bezpośrednio okazać wdzięczność, wręczając egzemplarze niniejszej publikacji. Specjalne podziękowanie należy się mojej rodzinie, która często musi się dzielić przynależnym jej czasem z moją pracą naukową. Dziękuję zatem wszystkim, bez wyjątku, którzy w różnoraki sposób wspierali mnie w badaniach na rzecz wdrażania rozwiązań w praktyce. Doceniam to bardzo.

W pierwszym rozdziale przedstawiono rozważania dotyczące celów, roli, rozumienia i znaczenia inżynierii bezpieczeństwa pożarowego. W rozdziale tym pod- 


\section{Badania i wdrożenia | Wstęp}

jęto ponadto próbę wskazania przyszłych potrzeb i perspektywy rozwoju tej dziedziny w naszym kraju. Część tę - podobnie jak pozostałe - zakończono wnioskami. W rozdziale drugim opisano wybrane zagadnienia dotyczące możliwości oraz determinantów wdrożenia nowych technologii i rozwiązań w obszarze ochrony przeciwpożarowej. Kolejno omówiono uwarunkowania formalne, wybrane zagadnienia dotyczące zaufania do wyrobów i rozwiązań, w tym ogólnie certyfikację, standaryzację, badania kwalifikacyjne, a także - konieczny zdaniem autora - indywidualny ekosystem dla innowacji. Zwrócono przy tym szczególną uwagę na współpracę, rolę nauki i praktyki w tym procesie. Rozdział trzeci poświęcono przybliżeniu wybranych zagadnień dotyczących badań na rzecz wdrożeń, z uwzględnieniem roli badań naukowych, m.in. dotyczących bezpieczeństwa pożarowego, a także współpracy i kooperacji nauki i biznesu na wszystkich etapach wprowadzania produktu na rynek - od badań do wdrożenia. Rozważania te, oparte na podejściu naukowym i praktycznym, podsumowano wnioskami, w tym odnoszącymi się do potrzeb i możliwości współpracy środowisk nauki i biznesu na rzecz skuteczniejszego wdrażania nowych rozwiązań i technologii.

Autor świadomie zastosował pewną dysproporcję pomiędzy objętością rozdziałów, wychodząc z założenia, iż w pierwszym z nich mają znaleźć się tylko najważniejsze, niezbędne treści (i to w możliwie najbardziej ogólnym, ale praktycznym ujęciu). O praktycznych walorach całej publikacji decydować mają przede wszystkim rozważania dotyczące prac badawczych, wdrożeń współpracy i innowacji. W sposób możliwie szczegółowy omówiono wyniki badań - tych zrealizowanych, realizowanych i dopiero rozpoczynanych - mających na celu poszukiwane nowych rozwiązań na rzecz ochrony przeciwpożarowej.

Za podstawę poniższych rozważań posłużyły między innymi prowadzone przez autora badania naukowe, praktyka i doświadczenie zawodowe w zakresie ochrony przeciwpożarowej. Do sformułowania wniosków i opinii autor wykorzystał także wiedzę zdobytą jako wykonawca oraz kierownik projektów rozwojowo-badawczych i badawczych ${ }^{4}$ (wygranych w ramach konkursu i zlecanych), reali-

4 1) Projekt pt. Sterowanie autonomicznym dronem za pomoca gogli (monookularu) z zakresu badań naukowych i prac rozwojowych na rzecz obronności i bezpieczeństwa państwa, finansowany przez NCBR ramach konkursu 9/2018, DOB-BIO9/26/04/2018; lata realizacji: 2018-2021;

2) Międzynarodowa sieć badawcza Uwarunkowania sprawności działania policji na poziomie lokalnym; realizacja w ramach współpracy jednostek naukowych i podmiotów publicznych, organizator: Komenda Wojewódzka Policji w Katowicach i partnerzy, Szkoła Policji w Katowicach; okres realizacji: II-IX.2018;

3) Zlecenie - pismo Komendy Głównej PSP znak CKR-I-0754/54-3/17 z dnia 29.12.2017 - dot. przeprowadzenia badań i przygotowania ekspertyzy naukowo-technicznej Sygnalizatory bezruchu. Analiza wymagań techniczno-użytkowych, laboratoryjne badania porównawcze, wnioski i rekomendacje formalnoprawne (ekspertyza naukowo-techniczna), okres realizacji: XII.2017 - III.2018, CNBOP-PIB. 
zowanych w większości w konsorcjach naukowo-przemysłowych z innymi niż CNBOP-PIB ${ }^{5}$ jednostkami naukowymi (uczelniami wyższymi, instytutami badawczymi), a także konsorcjantami przemysłowymi.

Prezentowane w publikacji wyniki badań, doświadczeń, wdrożeń i projektów odnoszą się w szczególności do uwarunkowań i specyfiki ochrony przeciwpożarowej. Przekonany jestem jednak, iż wiele z zagadnień i wniosków przedstawionych w rozdziale drugim ma dla szeroko rozumianego bezpieczeństwa charakter uniwersalny.

Wydanie publikacji możliwe było dzięki finansowaniu pozyskanemu w ramach projektu NCBR DOB-BIO9/26/04/2018 Sterowanie autonomicznym dronem za pomoca gogli (monookularu). Okres jego realizacji przypada na lata 2018-2021. Z uwagi na ograniczenia formalne w monografii tej nie są prezentowane wyniki przywołanego projektu. Zawarto jedynie odniesienia ogólne do tego przedsięwzięcia, jako jedną z form jego promocji.

\footnotetext{
4) The 7th Framework Programme of the European Commission DRIVER+, the Next Stage of Innovation in Crisis Management for European Resilience (DRIVER+, Kolejny Etap Innowacji w Zarządzanie Kryzysowe na Rzecz Europejskiej Odporności); lata realizacji: 2017-2018; wykonawca: SGSP;

5) Projekt pt. Opracowanie innowacyjnego sytemu zarzadzania bezpieczeństwem obiektów zabytkowych w zurbanizowanych centrach miast finansowany przez NCBR w ramach konkursu DOB-BIO7/08/01/2015; lata realizacji: 2015-2018; 6) Projekt pt. Metodyka oceny ryzyka na potrzeby systemu zarządzania kryzysowego RP z zakresu badań naukowych i prac rozwojowych na rzecz obronności i bezpieczeństwa państwa, finansowany przez NCBR w ramach konkursu DORB/0077/R/ID3/2013/03, lata realizacji: 2013-2015;

7) Projekt pt. Zaawansowane technologie teleinformatyczne wspomagajace projektowanie systemu ratowniczego na poziomach: gmina, powiat, województwo z zakresu badań naukowych i prac rozwojowych na rzecz obronności i bezpieczeństwa państwa, finansowany przez NCBR w ramach konkursu DOBR/0015/R/ID1/2012/03, lata realizacji: 2012-2015;

8) Projekt pt. Zintegrowany system budowy planów zarządzania kryzysowego w oparciu o nowoczesne technologie informatyczne z zakresu badań naukowych i prac rozwojowych na rzecz obronności i bezpieczeństwa państwa, finansowany przez NCBR w ramach konkursu DOBR/0016/R/ID2/2012/03, lata realizacji: 2012-2015.

5 Centrum Naukowo-Badawcze Ochrony Przeciwpożarowej im. Józefa Tuliszkowskiego - Państwowy Instytut Badawczy.
} 


\section{Inżynieria bezpieczeństwa pożarowego}

$\mathrm{P}$ ojęcie inżynierii bezpieczeństwa nie jest nowe. Według jednej z proponowanych definicji ${ }^{1}$ odnosi się do planowania, projektowania, budowania, organizowania i funkcjonowania systemów związanych z koniecznością przeciwdziałania zagrożeniom ogółu ludzkości, środowiska naturalnego oraz dóbr cywilizacyjnych. Inżynieria bezpieczeństwa to między innymi jeden z kierunków studiów oferowanych na uczelniach wyższych. Popularne obecnie specjalności to na przykład inżynieria bezpieczeństwa technicznego czy inżynieria bezpieczeństwa cywilnego. Innym przykładem jest kierunek studiów w Szkole Głównej Służby Pożarniczej - inżynieria bezpieczeństwa pożarowego. Dalszą część niniejszego rozdziału poświęcono omówieniu pojęcia inżynierii bezpieczeństwa w ujęciu przede wszystkim inżynierii bezpieczeństwa pożarowego.

\subsection{Rozumienie i znaczenie}

Prezentację podstaw inżynierii bezpieczeństwa odnaleźć można w licznych, interdyscyplinarnych źródłach. O systemach bezpieczeństwa pisze między innymi P. Sienkiewicz w publikacji zatytułowanej Inżynieria systemów bezpieczeństwa ${ }^{2}$. Autor założył, iż zasadne jest umiejscowienie wskazanych zagadnień dotyczących bezpieczeństwa ${ }^{3} \mathrm{~W}$ obszarze szeroko rozumianej inżynierii systemów ${ }^{4}$. W rozdziale poświęconym teorii i inżynierii bezpieczeństwa systemów stwierdza, iż na gruncie politologii i badań nad bezpieczeństwem stosowane są przede wszystkim kryteria:

- zasięgu bezpieczeństwa (np. regionalne),

- przedmiotowe (bezpieczeństwo militarne, ekonomiczne, technologiczne itp.).

Na gruncie analizy systemowej P. Sienkiewicz wskazuje na dominację dwóch ujęć bezpieczeństwa:

1 A. Mizerski, dz. cyt.

2 P. Sienkiewicz, Inżynieria systemów bezpieczeństwa, Polskie Wydawnictwo Ekonomiczne S.A., Warszawa 2015.

3 „Publikację poświęcono systemom bezpieczeństwa, które mają na celu zabezpieczenie (ochronę) określonych obiektów (np. systemów społecznych, systemów technicznych) przed realnymi bądź potencjalnymi zagrożeniami ich bezpieczeństwa”. Źródło: Tamże, s. 8.

4 „Inżynieria systemów zajmuje się analizą, projektowaniem i doskonaleniem systemów działania (organizacji, instytucji) oraz systemów technicznych itp.”. Źródło: jw. 
- rozumianego jako własnośćs systemu charakteryzującą jego odporność na powstanie sytuacji niebezpiecznej,

- rozumianego jako zdolność systemu do ochrony wewnętrznej wartości przed zewnętrznym zagrożeniem.

Zagrożenie bezpieczeństwa systemu w cytowanej publikacji jest natomiast określane jako każde zjawisko, proces, zdarzenie niepożądane z punktu widzenia niezakłóconej pracy systemu.

W roku akademickim 2008/2009 w ofercie dydaktycznej Wydziału Mechatroniki Wojskowej Akademii Technicznej dotyczącej studiów pierwszego stopnia na kierunku inżynieria bezpieczeństwa napisano: „Inżynieria bezpieczeństwa (safety engineering) wyrosła z problemów związanych z koniecznością przeciwdziałania zagrożeniu ogółu ludzkości i całego środowiska naturalnego jak i dóbr cywilizacji przez energetykę jądrową oraz chronienia stosunkowo nielicznej, lecz wąsko wyspecjalizowanej, o wysokich umiejętnościach grupy ludzi (astronautów) przed niebezpieczeństwami lotów kosmicznych i stała się w ciągu ostatnich dwóch dziesięcioleci samodzielną dyscypliną nauki”.

W dalszej części przywołanej oferty dydaktycznej stwierdza się, iż zakres zainteresowań inżynierii bezpieczeństwa nie ograniczył się do energetyki jądrowej oraz astronautyki - w chwili obecnej obejmuje praktycznie wszystkie obszary techniki (jak chociażby przemysł chemiczny, transport, przemysł wydobywczy, energetykę konwencjonalną, budownictwo). Poza niezaprzeczalnym znaczeniem inżynierii bezpieczeństwa w technice podkreślić należy jej rolę w skutecznym przeciwdziałaniu i opanowaniu negatywnych skutków wywołanych bezpośrednio przez zjawiska naturalne - takie jak trzęsienia ziemi, huragany, lawiny, powodzie - oraz poprzez umyślne i nieumyślne destrukcyjne działania ludzi (awarie techniczne, a także działania terrorystyczne i akty sabotażu).

W tym samym materiale zwrócono uwagę, iż należy rozróżnić bezpośredni i pośredni sposób oddziaływania obydwu powyższych czynników. Bezpośrednie oddziaływanie od razu prowadzi do negatywnych skutków, natomiast jego forma pośrednia czyni to drogą wywołania negatywnego oddziaływania obiektów technicznych na otoczenie - dopiero wskutek tego powstanie szkód. Na przykład trzęsienie ziemi może od razu skutkować śmiercią ludzi (sposób bezpośredni) albo też śmierć ta może zostać spowodowana przez substancje toksyczne wydzielone

5 „Rozumianej jako zawodności systemu bezpieczeństwa obiektu, czyli jego podatność na powstanie sytuacji niebezpiecznej”. Źródło: Tamże, s. 9.

6 A. Olejnik, W. Pihowicz, A. Skomra, Wydział Mechatroniki inżynieria bezpieczeństwa - nowa oferta dydaktyczna Wydziału Mechatroniki Wojskowej Akademii Technicznej, Wojskowa Akademia Techniczna, Warszawa 2008. 
do otoczenia z uszkodzonej infrastruktury fabryki (sposób pośredni). Celem działań inżynierii bezpieczeństwa jest racjonalna maksymalizacja ochrony ludzi, środowiska naturalnego i dobór cywilizacji. Środek do celu to właściwa kombinacja pozytywnych realizacji zadań dwóch zasadniczych specjalności - inżynierii bezpieczeństwa technicznego i inżynierii bezpieczeństwa cywilnego7.

Wśród ugruntowanych ${ }^{8}$ akademickich i eksperckich definicji, sposobów rozumienia i stosowania inżynierii bezpieczeństwa pojawiają się nowe propozycje oraz potrzeby. W dzisiejszej rzeczywistości konieczna jest specjalizacja. Obserwujemy jej stopniowe zawężanie z uwagi na coraz większą złożoność zagadnień. Kompetencje inżyniera bezpieczeństwa znacząco zmieniły się w ostatnich latach. Jedną ze specjalności w zakresie inżynierii bezpieczeństwa jest inżynieria bezpieczeństwa pożarowego. Pojęciem tym operują zarówno środowiska akademickie, naukowe, jak i eksperckie (produkujące, projektujące, instalujące, konserwujące i eksploatujące techniczne systemy zabezpieczeń przeciwpożarowych, a także sprzęt i wyposażenie straży pożarnej). M. Cupryjak, T. Czapewski i M. Jasztal w pracy zbiorowej pod tytułem Przeciwdziałanie zagrożeniom i skutkom zamachów terrorystycznych w kontekście bezpieczeństwa Gazoportu w Świnoujściu, cytując za A. Ostrokólskim, inżynierię bezpieczeństwa pożarowego definiują jako dyscyplinę, której celem jest opracowywanie, doskonalenie i upowszechnianie metod i środków racjonalnej maksymalizacji skuteczności ochrony ludzi, środowiska naturalnego i dóbr cywilizacji poprzez:

- zapobieganie powstawaniu zagrożeniom bezpieczeństwa: naturalnym, cywilizacyjnym, publicznym oraz związanym z eksploatacją artefaktów,

- przygotowanie podmiotów i systemu bezpieczeństwa na wypadek wystąpienia zagrożeń,

- reagowanie na negatywne skutki wyzwalających się zagrożeń bezpieczeństwa człowieka i jego środowiska.

Cel ten jest urzeczywistniany poprzez cztery - ugruntowane już pojęciowo, metodycznie i narzędziowo - wzajemnie uzupełniające się nurty dyscypliny naukowej i kierunku kształcenia, jakim jest inżynieria bezpieczeństwa: (1) inżynierię bezpieczeństwa technicznego, (2) inżynierię bezpieczeństwa cywilnego, (3) inżynierię bezpieczeństwa publicznego, (4) inżynierię bezpie-

7 Tamże.

$8 \quad$ Patrz na przykład:

C. Cempel, Teoria i inżynieria systemów - zasady i zastosowania myślenia systemowego, Wydawnictwo Naukowe ITE PIB, Poznań 2008, s. 25; Inżynieria bezpieczeństwa pożarowego oparta o cele funkcjonalne - Poradnik inżynierski SFPE, tłum. P. Tofiło, Stowarzyszenie Inżynierów Bezpieczeństwa Pożarowego, Warszawa 2007. 
czeństwa pracy. Mogą być one w całej rozciągłości uznane za jej specjalności. Znaczna część problemów zarządzania bezpieczeństwem dziedzinowym jest wspólna, niezależnie od obszaru, którego dotyczy. Natomiast metody i rozwiązania teleinformatycznego wspomagania zarządzania bezpieczeństwem stanowią domenę (5) inżynierii systemów zarządzania bezpieczeństwem, jako specjalności dyscypliny naukowej i kierunku kształcenia9

Mając na uwadze przedstawioną powyżej propozycję rozumienia i umiejscowienia inżynierii bezpieczeństwa, zawężając jednak rozważania te do inżynierii bezpieczeństwa pożarowego, można sformułować następujące wnioski. Wśród rozwiązań technologicznych i technicznych systemu ochrony przeciwpożarowej i/lub tych powstałych na jego potrzeby, wyróżnić można między innymi ${ }^{10}$ dorobek inżynierii bezpieczeństwa pożarowego, a w jej ramach na przykład narzędzia do prowadzenia symulacji rozprzestrzeniania się ciepła i dymu w obiektach budowlanych (wykorzystywane w praktyce projektowania i wykonywania instalacji ${ }^{11}$. Rozwiązania technologiczne i techniczne w ochronie przeciwpożarowej stosuje się w celu zapewnienia:

- bezpieczeństwa pożarowego obiektów budowlanych,

- niezawodności sprzętu i wyposażenia straży pożarnej, a dzięki temu możliwości i skuteczności prowadzenia działań ratowniczo-gaśniczych,

- bezpieczeństwa ratowników wyposażonych między innymi w środki ochrony indywidualnej ${ }^{12}$ oraz sprzęt i wyposażenie ratownicze.

9 M. Cupryjak, T. Czapewski, M. Jasztal i in., Przeciwdziałanie zagrożeniom i skutkom zamachów terrorystycznych w kontekście bezpieczeństwa Gazoportu w Świnoujściu, Wydawnictwo ZAPOL, Szczecin 2013, s. 142.

10 Wśród rozwiązań technologicznych i technicznych systemu ochrony przeciwpożarowej wyróżnić można ponadto: - sprzęt i wyposażenie jednostek ochrony przeciwpożarowej i podmiotów ratowniczych, zapewniające zdolność do ciągłości działania (w tym np. systemy łączności i bazy danych o substancjach niebezpiecznych, obiektach budowlanych, sprzęcie i wyposażeniu);

- wymagania przepisów ochrony przeciwpożarowej dla obiektów budowlanych i terenów (w zakresie stosowania zabezpieczeń czynnych i biernych, właściwości wyrobów użytkowanych na potrzeby ochrony przeciwpożarowej); - techniczne systemy zabezpieczeń i urządzenia przeciwpożarowe stosowane w obiektach budowlanych, a także formalne wymagania dotyczące ich wykorzystania, projektowania, instalowania, odbiorów (weryfikacji poprawności działania), konserwacji w trakcie eksploatacji;

- wymagania przepisów ochrony przeciwpożarowej dotyczące obowiązków właścicieli i użytkowników obiektów budowlanych w zakresie wyposażania i użytkowania obiektów i terenów, pojazdów oraz organizowania imprez masowych i transportu, utrzymania stanu bezpieczeństwa, wykonywania robót niebezpiecznych, a także projektowania, wznoszenia i eksploatacji obiektów budowlanych.

11 Symulacje te prowadzone są na podstawie właściwych dokumentów normatywnych, na przykład: ISO/TR 13387-1: 1999 Fire safety engineering - Part 1: Application of fire performance concepts to design objectives, ISO/TR 16732-3: 2013 Fire safety engineering - Fire risk assessment - Part 3: Example of an industrial property.

12 Ubranie specjalne strażaka, hełm, rękawice, maska i aparat powietrzny, szelki ratownicze itd. 
Pojawia się zatem pytanie: jak rozumiana jest aktualnie inżynieria bezpieczeństwa pożarowego w naszym kraju? Pojęcie to jest używane w środowisku akademickim i naukowym, a także eksperckim. Z punktu widzenia nauki dyskusję na temat istoty i rozumienia inżynierii bezpieczeństwa pożarowego należy rozpocząć od celów ochronnych. Zagadnienia te zostały szczegółowo przedstawione między innymi w jednej z wcześniejszych publikacji autora pt. Certyfikacja ustug $w$ ochronie przeciwpożarowej $w$ ujęciu praktycznym i teoretycznym ${ }^{13}$. W cytowanej monografii na podstawie prowadzonych badań opisano szczegółowo działania ochrony przeciwpożarowej ${ }^{14}$, będące jednocześnie jej trzema filarami (w rozumieniu rozróżnianych działań powiązanych ze sobą) służącymi do osiąganiu celów ochronnych - ratowania życia i zdrowia oraz mienia i środowiska. Cele te wynikają wprost z zapisów ustawy o ochronie przeciwpożarowej. Priorytet ochrony życia i zdrowia nie budzi wątpliwości. Cele ochrony życia i zdrowia, mienia i środowiska mogą się przenikać. W przywołanej publikacji przedstawiono wyjaśnienie celów ochronnych w ramach ochrony przeciwpożarowej z ograniczeniem do pożarów. W polskiej literaturze dotyczącej ochrony przeciwpożarowej cele ochronne nie są jednak szczegółowo analizowane i omawiane.

W dalszych rozważaniach dotyczących inżynierii bezpieczeństwa pożarowego przydatny jest zatem dorobek zawarty między innymi w europejskich i międzynarodowych dokumentach normatywnych. Źródłem informacji i wiedzy są także dostępne normy międzynarodowe. Za ISO/TR 13387-1:1999(E) przywołać można następującą definicję: „Inżynieria bezpieczeństwa pożarowego oparta jest na uzasadnionej naukowo wiedzy o zjawiskach pożarowych, w tym jak one oddziałują na człowieka, jego zachowania i na tej podstawie polega na stosowaniu zasad, reguł i rozwiązań (czynnych i biernych) inżynierskich i eksperckich (środków ochrony przeciwpożarowej)”15. Na poniższej rycinie przedstawiono istotę i rozumienie inżynierii bezpieczeństwa pożarowego opracowaną na podstawie ISO/TR 13387-1:1999(E).

J. Zboina, P. Gancarczyk, Certyfikacja usług w ochronie przeciwpożarowej..., dz. cyt. 


\title{
INŻYNIERIA BEZPIECZEŃSTWA POŻAROWEGO
}

\begin{abstract}
wiedza, nauka o zjawiskach pożarowych
uzasadniona naukowo wiedza poprzez prowadzone badania, eksperymenty, analizy, oceny, a także doświadczenia i obserwacje
\end{abstract}

\begin{tabular}{c}
\hline+ \\
wiedza, nauka o oddziaływaniu pożaru na człowieka \\
ijego zachowanie
\end{tabular}

Ryc. 1 Inżynieria bezpieczeństwa pożarowego - istota i rozumienie

Źródło: Opracowanie własne, uzupełnione na podstawie ISO/TR 13387-1:1999(E) Fire safety engineering - Part 1: Application of fire performance concepts to design objectives, International Organization for Standardization, Geneve 1999.

Inżynieria bezpieczeństwa pożarowego jest w powyższym rozumieniu narzędziem stosowanym do projektowania i realizacji ochrony przeciwpożarowej, prewencyjnej oceny bezpieczeństwa pożarowego w obiektach budowlanych oraz do realizacji celów ochronnych. Jeden z dokumentów normatywnych poruszających ten temat wyszczególnia wśród celów ochronnych następujące obszary:

- ochrona życia i zdrowia,

- ochrona mienia,

- ochrona środowiska,

- określanie zagrożeń oraz ryzyka wystąpienia pożaru,

- szacowanie jego skutków, 
- analityczna ocena optymalnych ${ }^{16}$ środków ochrony przeciwpożarowej (zabezpieczających i zapobiegawczych) ${ }^{17}$.

Nieco inaczej cele ochrony przeciwpożarowej przedstawiono w międzynarodowym dokumencie normatywnym ISO 23932:2009 Fire safety engineering - General principles. Cele te są wzajemnie ze sobą powiązane, nieprzypadkowa jest też ich kolejność (hierarchia). Jako pierwsza wymieniana jest ochrona zdrowia i życia (ratowanych i ratowników). Kolejne cele to odpowiednio ochrona mienia i ochrona środowiska. Są one osiągane przez te same lub odmienne działania ochrony przeciwpożarowej przy zastosowaniu środków przeznaczonych do zabezpieczenia mienia czy środowiska. Zapewnienie ciągłości funkcjonowania to dodatkowy ważny cel, do którego polskie przepisy prawa dotyczące ochrony przeciwpożarowej nie odnoszą się wprost. Ujęcie celów ochronnych proponowane przez ISO 23932:200918 można przedstawić graficznie. Na poniższej rycinie wskazano opisane powyżej cele, oznaczając (w ramce) te wynikające wprost z ustawy o ochronie przeciwpożarowej.

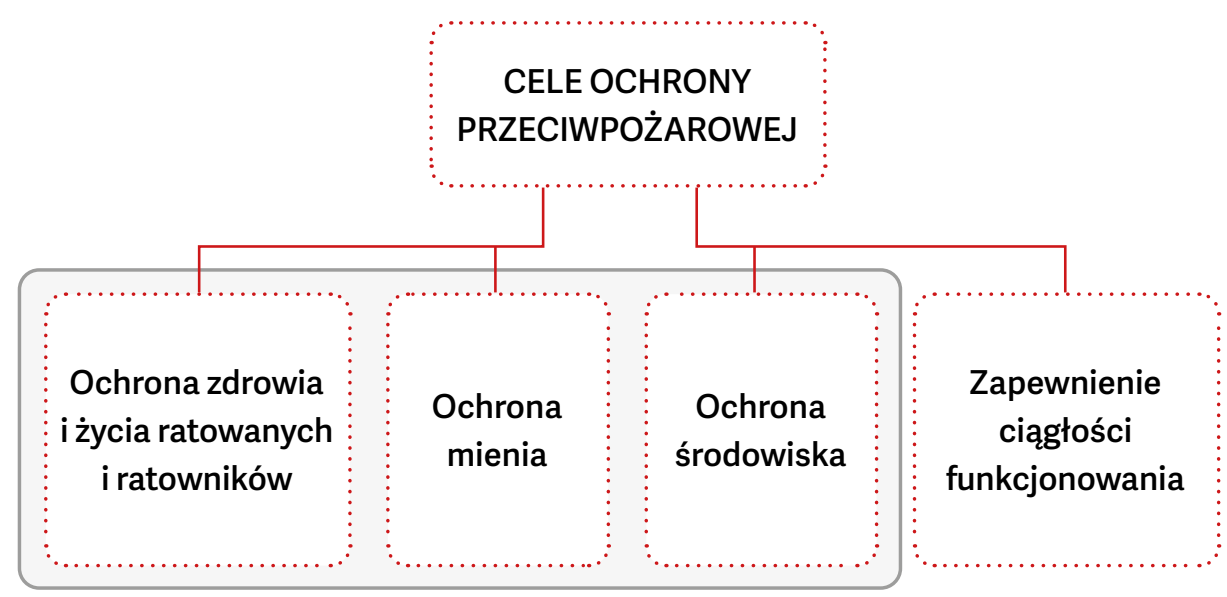

Ryc. 2. Cele, istota ochrony przeciwpożarowej

Źródło: Opracowanie własne na podstawie T. Kiełbasa, J. Zboina, D. Gajownik, Inżynieria bezpieczeństwa pożarowego, w: Ochrona przeciwpożarowa a bezpieczeństwo państwa, J. Zboina, B. Wiśniewski (red.), Wydawnictwo CNBOP-PIB, Józefów 2014, s. 111.

\footnotetext{
16 W rozumieniu - proporcjonalnych, skutecznych, ekonomicznie uzasadnionych

17 ISO/TR 13387-1:1999(E) Fire safety engineering - Part 1, dz. cyt., s. 3.

18 ISO 23932:2009 Fire safety engineering - General principles, s. 6.
} 
Tak rozumiana inżyniera bezpieczeństwa pożarowego - przynajmniej w części - wprost wpisuje się swoim zakresem w inżynierię środowiska. Dziedzina ta obejmuje szeroko rozumiane przedsięwzięcia inżynierskie ukierunkowane na zachowanie stanu równowagi środowiska przyrodniczego oraz umożliwienie jego zdolności do samoregeneracji i samooczyszczania oraz odtworzenia walorów przyrodniczych. Cytując dalej za D. Lipińską, „,inżynieria środowiska dostarcza naukowych podstaw racjonalnego gospodarowania zasobami przyrody oraz prognozowania, oceny, zapobiegania i naprawy negatywnych skutków niszczenia tych zasobów. Dodatkowo ważnym celem inżynierii środowiska jest edukowanie społeczeństwa w zakresie podejmowanych działań technicznych" ${ }^{\text {. }}$.

Obecnie do realizacji wskazanych powyżej celów ochronnych powszechnie wykorzystywana jest inżynieria bezpieczeństwa pożarowego. Stosowana jest ona odpowiednio do wszystkich działań ochrony przeciwpożarowej, choć w różnym zakresie. Najczęściej inżynierię bezpieczeństwa pożarowego wykorzystuje się w działaniach prewencyjnych (projektowanie, instalowanie, konserwacja i eksploatacja czynnych i biernych zabezpieczeń przeciwpożarowych w obiektach budowlanych). Inżynieria bezpieczeństwa pożarowego służy również jako narzędzie do doskonalenia i optymalizacji działań operacyjnych w ramach ochrony przeciwpożarowej. Przykładem w tym zakresie może być oprogramowanie wspomagające rozmieszczenie zasobów ludzkich, sprzętu i wyposażenia straży pożarnej ${ }^{20}$. Przydatna jest także w obszarze profilaktyki i edukacji społecznej. W tym zakresie poszukiwane są rozwiązania, które pozwoliłyby na mierzenie skuteczności podejmowanych działań21.

\subsection{Perspektywy rozwoju i potrzeby}

Powyższa próba przybliżenia obecnego rozumienia i definiowania inżynierii bezpieczeństwa pożarowego prowadzi do kolejnych pytań i wniosków. Podstawowym pytaniem jest, zdaniem autora, to dotyczące wyzwań stojących przed inżynierią bez-

19 D. Lipińska, Podstawy inżynierii środowiska, Wydawnictwo Uniwersytetu Łódzkiego, Łódź 2016, s. 13.

20 Jest to wynik projektu pt. Zaawansowane technologie teleinformatyczne wspomagajace projektowanie systemu ratowniczego na poziomach: gmina, powiat, województwo realizowanego na rzecz obronności i bezpieczeństwa państwa, finansowanego przez NCBR (konkurs nr 3/2012 na wykonanie projektów w zakresie badań naukowych lub prac rozwojowych na rzecz obronności i bezpieczeństwa państwa); konsorcjum naukowe projektu: SGSP, CNBOP-PIB, Uczelnia Techniczno-Handlowa im. Heleny Chodkowskiej, ASSECO Poland S.A., ITTI Sp. z o.o.; lata realizacji: 2012-2015. Szerzej tematykę tę przedstawiają:

J. Kielin, D. Bąk, Projektowanie systemu ratowniczego - wstępny raport z badań, w: Ochrona przeciwpożarowa a bezpieczeństwo państwa, J. Zboina, B. Wiśniewski (red.), Wydawnictwo CNBOP-PIB, Józefów 2014.

J. Zboina, J. Kielin, Projektowanie systemu ratowniczego, Wydawnictwo CNBOP-PIB, Józefów 2015.

21 W obszarze działań profilaktyki i edukacji społecznej na rzecz ochrony przeciwpożarowej poszukiwane są narzędzia do „ewaluacji i szacowania” skuteczności prowadzonych działań, na przykład kampanii. Aktualnie takie narzędzia nie są dostępne - są one dopiero przedmiotem badań i prac projektowych. 
pieczeństwa pożarowego w najbliższym czasie w Polsce. W poprzednim podrozdziale wskazano zakres stosowania inżynierii bezpieczeństwa pożarowego odpowiednio do działań: 1) prewencyjnych, 2) ratowniczych, 3) profilaktyki i edukacji społecznej. Ustalono, iż najszersze zastosowanie znajduje w obszarze prewencji pożarowej, rozumianej jako stosowanie czynnych i biernych zabezpieczeń przeciwpożarowych. Od co najmniej kilku lat ten obszar działań jest wspierany przez liczne narzędzia inżynierskie 22 . Powstają również nowe rozwiązania i wdrożenia oparte najczęściej na łączeniu technologii i urządzeń IT. Przykładem może być obiecujące i systematycznie doskonalone rozwiązanie pod nazwą Platforma aplikacji przeciwpożarowych stanowiące interaktywne narzędzie wymiany informacji dotyczących bezpieczeństwa pożarowego. Aplikacja dedykowana pierwotnie współpracy rzeczoznawcy ds. zabezpieczeń przeciwpożarowych i projektanta uzyskuje nowe funkcjonalności ${ }^{23}$. „Widzimy przyszłość projektowania” - możemy przeczytać na stronie głównej tej platformy. Czy to jeden z kierunków rozwoju inżynierii w ochronie przeciwpożarowej? Opisywane narzędzie może usprawniać prace projektowe w zakresie ochrony przeciwpożarowej i doboru urządzeń ppoż. Na obecnym etapie posiada wiele użytecznych funkcjonalności i nadal jest ulepszane.

22 Na przykład:

1) Symulacje komputerowe przy użyciu metod numerycznej mechaniki płynów (ang. Computational Fluid Dynamics - CFD) umożliwiają prognozowanie sposobu rozprzestrzeniania się dymu i ciepła w przestrzeniach. Symulacje te są alternatywnym dla innych metod inżynierskich narzędziem, umożliwiającym rozwiązywanie określonych problemów w praktyce. Prowadzenie symulacji CFD wymaga wyposażenia oraz odpowiednich kwalifikacji. Aktualnie w inżynierii bezpieczeństwa pożarowego symulacje CFD są stosowane najczęściej do: prognozowania warunków podczas ewakuacji w przypadku pożaru, weryfikacji - na etapie projektowym - poprawności przyjętego rozwiązania w zakresie oddymiania budynku, prognozowania temperatur w przestrzeni objętej pożarem, na potrzeby analizy zachowania się elementów konstrukcji.

2) Program CIS KOSMAS® (stosowany przez niemiecką straż pożarną) pozwala na modelowanie systemu ratowniczego dla określonego obszaru z uwzględnieniem wszystkich podstawowych czynników mających wpływ na bezpieczeństwo pożarowe. Program CIS-KOSMAS® przedstawia miasto jako obszar o danej konfiguracji wraz z lokalizacją jednostek ratowniczo-gaśniczych straży pożarnej, rejonów operacyjnych, wyposażenia jednostek ratowniczo-gaśniczych itp. Podczas modelowania przemieszczania się pojazdów pod uwagę brana jest rzeczywista prędkość przejazdu przez dany obszar oraz ukształtowanie dróg. System za pomocą grafiki przedstawia istniejący układ dróg, który umożliwia znacznie bardziej szczegółową analizę procesu, np. automatyczne określanie najkrótszej i najszybszej trasy przejazdu dla wysyłanych do akcji pojazdów (przy założeniu maksymalnych prędkości przejazdu na różnych ulicach).

3) Numer projektu: DOB-BIO7/09/03/2015; nazwa: Program do oceny ryzyka w obiektach przemysłowych, stwarzajacych zagrożenie poza swoim terenem; akronim: EVARIS.

Cele PAP24: „Wymiany informacji - Usprawnienie wymiany informacji pomiędzy projektantami a rzeczoznawcami ds. zabezpieczeń przeciwpożarowych, przeznaczonych do uzgodnienia projektu budowlanego w celu potwierdzenia zgodności zawartych w nim rozwiązań z wymaganiami ochrony przeciwpożarowej. Wspomaganie pracy - Wspieranie pracy projektanta poprzez interaktywną platformę, działającą w sposób zgodny z zasadami wiedzy technicznej i aktualnymi rozporządzeniami. Poszerzenie świadomości - Poszerzenie świadomości użytkowników, z uwagi na zawarte zagadnienia ochrony przeciwpożarowej. Główne funkcjonalności PAP24: „Interaktywny formularz do pracy, udostępnianie projektów w aplikacji, generowanie dokumentacji, dobór urządzeń”. Źródło: https:// pap24.pl/o-platformie/cele/ [dostęp: 1.02.2020]. 
U wielu osób mogą jednak pojawiać się obawy związane z powierzeniem danych (umieszczanych przez użytkownika podczas pracy w aplikacji), wynikające z ostrożności. Mogą również nie dostrzegać wszystkich korzyści, jakie płyną ze stosowania narzędzia. Dlatego wydaje się, że masowe wykorzystanie narzędzia uzależnione będzie od umiejętności przezwyciężenia przez twórców i właścicieli aplikacji tych klasycznych „oporów”. Ludzie nie robią ${ }^{24}$ bowiem czegoś (nie stosują rozwiązania), gdy po prostu nie chcą, nie potrafią tego używać lub gdy oceniają, że subiektywnie oszacowane koszty są wyższe od postrzeganych korzyści.

Kierunek stosowania rozwiązań inżynierskich znajduje swoje odzwierciedlenie również w pracach legislacyjnych. Poszukiwane są nowe rozwiązania wykorzystujące potencjał rozwiązań inżynierskich, co według założeń ma być ułatwieniem i przyczyniać się do jeszcze szybszego rozwoju - między innymi - branży budowlanej25. Ten kierunek jest obecny zarówno w legislacji krajowej, jak i Unii Europejskiej²6.

24 Inspirować w tym zakresie może model chcieć-móc-potrafić: „Aby rozwiązać większość problemów, warto zrobić krok w tył i rzetelnie odpowiedzieć na pytanie, dlaczego pracownicy nie robią tego, co powinni (w powyższym kontekście rozumiane jako próba ustalenia, czego oczekuje dostawca rozwiązania)? Dlaczego nie realizują planów, celów sprzedażowych, ociągają się, nie dbają o relacje z klientami (w kontekście stosowania rozwiązania PAP24)? Doświadczenia pokazują, że przyczyny nieefektywności sprowadzają się do trzech głównych powodów:

- pracownicy nie chcą (czyli brak im motywacji) lub/i;

- pracownicy nie mogą (warunki oferowane przez firmę są nieadekwatne do potrzeb pracowników) lub/i;

- pracownicy nie potrafią (pracownicy nie posiadają wymaganych od nich kompetencji)”. Źródło: chciec-moc-potrafic-dlaczego-ludzie-nie-robia-tego-co-powinni-niezbednik-menedzera/, https://hrnews.pl/ [dostęp: 1.02.2020].

W artykule pt. Zmienia się prawo budowlane. Ma być prościej i szybciej możemy przeczytać między innymi: „Nadmierna liczba dokumentów, których wymaga się na samym starcie inwestycji, wydłuża proces budowy. Obecnie organ, który wydaje pozwolenie na budowę, nie weryfikuje projektu pod kątem technicznym, a jedynie sprawdza kompletność dokumentów. Projekt techniczny, który stanowi około 35 procent całej dokumentacji, to szczególne warunki techniczne i bardzo szczegółowe opisy dla danego obiektu budowlanego. Często zmienia się on w procesie inwestycyjnym. Teraz projekt techniczny będzie mógł być wykonany po uzyskaniu pozwolenia na budowę, ale przed rozpoczęciem prac budowlanych - wyjaśnia wiceminister rozwoju Robert Nowicki. - Obowiązkiem kierownika budowy będzie posiadanie aktualnego projektu technicznego, a projektant będzie wydawał oświadczenie o jego poprawności. Dzięki temu zostaną dochowane warunki bezpieczeństwa, a jednocześnie proces skróci się po stronie inwestora. Również urzędy będą miały ułatwioną pracę, bo to kilkanaście milionów stron dokumentacji rocznie...” Źródło: https://www.slaskibiznes.pl/wiadomosci,zmienia-sie-prawo-budowlane-ma-byc-prosciej-i-szybciej,wia5-1-2481.html [dostęp: 03.02.2020].

BIM - technologia parametrycznego modelowania informacji o budynku (ang. Building Information Modeling) „to koncepcja, która całkowicie zmienia podejście do projektowania, realizacji inwestycji i zarządzania budynkiem. BIM, czyli modelowanie informacji o budynku, umożliwia ciągły i natychmiastowy dostęp do bieżących informacji o projekcie i wszystkich kosztach. BIM to koncepcja, która zrewolucjonizowała podejście do projektowania, realizacji inwestycji i zarządzania budynkiem. Umożliwia ciągły i natychmiastowy dostęp do informacji o projekcie, jego kosztach i harmonogramach. Upraszcza także sam proces projektowy, poprzez możliwość testowania w świecie wirtualnym rozmaitych wariantów i schematów w celu wybrania optymalnego. Wyniki testów są spójne i wiarygodne dzięki coraz lepszemu odzwierciedleniu rzeczywistości poprzez jeden cyfrowy model. Może on być wykorzystywany do podejmowania decyzji projektowych, opracowania spójnej dokumentacji budowlanej oraz analiz zyskowności i szacowania kosztów inwestycji, a docelowo także do zarządzania obiektem”. Źródło: B. Kawecka-Zygadło, BIM - technologia parametrycznego modelowania informacji o budynku, https://www.muratorplus.pl/technika/programy/bim-innowacyjna-technologia-parametrycznego-modelowania-informacji-o-budynku-aa-h4hz-msdd-YXYr.html [dostęp: 03.02.2020]. 
Perspektywy rozwoju zastosowań inżynierii bezpieczeństwa pożarowego w obszarze działań prewencyjnych są zatem najszersze. Paradoksalnie jednak ich progres może być najmniej dostrzegalny, ponieważ aktualnie jest ona już dość intensywnie wykorzystywana w praktyce ochrony przeciwpożarowej. Natomiast można przewidywać znacząco szersze niż obecne wykorzystanie inżynierii bezpieczeństwa pożarowego w obszarze działań ratowniczych. Rozwiązania, oprogramowanie i dedykowane urządzenia będą w najbliższym czasie znajdować masowe zastosowanie jako niezbędny sprzęt i wyposażenie straży pożarnej, podobnie jak urządzenia i rozwiązania wspierające ich prowadzenie. Możliwości i potrzeby dostrzegane są również w obszarze organizacji działań. Znacząco szersze wykorzystanie inżynierii bezpieczeństwa pożarowego w strefie działań ratowniczych można prognozować przede wszystkim dlatego, iż aktualnie - w porównaniu do działań prewencyjnych - jej zastosowanie w tym obszarze nie jest zbyt powszechne. Projektowanie systemu ratowniczego ${ }^{27}$ staje się coraz bardziej oczywistą potrzebą w polskiej straży pożarnej. Badania w tym zakresie, a także - przede wszystkim - możliwości prowadzenia symulacji przy użyciu dedykowanego oprogramowania pozwalają lepiej określić zapotrzebowanie na zasoby ludzkie i materialne oraz ich rozmieszczenie. Stosowanie dedykowanych rozwiązań IT, które są wynikiem prac badawczych, pozwala na optymalizację rozmieszczenia i wykorzystania zasobów, a tym samym poprawę dostępności usługi ratowniczej na danym terenie ${ }^{28}$. Przywołany już wcześniej, wdrożony i stosowany w niemieckiej straży pożarnej, system symulacji CIS KOSMAS ${ }^{\circledR}$ daje ogromne możliwości analizy funkcjonowania służb ratowniczych. Jest on prosty w obsłudze i posiada przyjazny interfejs, co pozwala na korzystanie z niego pracownikom służb ratowniczych oraz administracji miasta, a także innym podmiotom według potrzeb. Oprogramowanie CIS KOSMAS ${ }^{\circledR}$ jest skutecznym narzędziem analitycznym wielu aspektów funkcjonowania służb ratowniczych oraz wypracowania optymalnego rozmieszczenia jednostek ratowniczych na danym obszarze.

Wykorzystanie inżynierii bezpieczeństwa pożarowego na potrzeby optymalizacji i wsparcia działań ratowniczych jest aktualnie coraz bardziej dostrzeganą potrzebą w naszym kraju. Dedykowane rozwiązania w tym zakresie są już stosowane w innych państwach nie tylko do projektowania systemu ratowniczego, ale także do bieżącego zarządzania jego zasobami. Nadal nie są to rozwiązania często

27 J. Kielin, D. Bąk, Projektowanie systemu ratowniczego - wstępny raport z badań, dz. cyt.

28 Badania prowadzone w ramach projektu pt. Zaawansowane technologie teleinformatyczne wspomagajace projektowanie systemu ratowniczego na poziomach: gmina, powiat, województwo realizowanego na rzecz obronności i bezpieczeństwa państwa; finansowanego przez NCBR - konkurs nr 3/2012. 
stosowane. CIS KOSMAS ${ }^{\circledR}$ użytkowane jest przez niemiecką straż pożarną, a dzięki zrealizowanemu projektowi badawczemu ${ }^{29}$ oprogramowanie jest również dostępne dla straży w Polsce. Przykłady te dowodzą, iż w przyszłości wykorzystanie na potrzeby ratownictwa dedykowanych narzędzi i rozwiązań inżynierskich będzie większe niż obecnie. Wsparcie i nowe możliwości wynikające ze stosowania tych rozwiązań pozwala bowiem zarówno optymalizować skuteczność prowadzonych działań, jak i obniżać ich koszty.

Główny cel działań podejmowanych w ramach profilaktyki i edukacji społecznej to podnoszenie świadomości ludzi na temat zagrożeń w przypadku pożaru ${ }^{30}$ i kształtowanie ich poprawnych zachowań (ze zdolnością do samoratowania i pomocy innym włącznie). Zagrożenia ${ }^{31}$ - mimo iż dobrze zdefiniowane - nie są nadal powszechnie znane. $Z$ tego powodu zdolności do samoratowania, podjęcia działań ratowniczo-gaśniczych i pomocy innym nadal nie można ocenić jako satysfakcjonującej. Ponadto trudności nastręcza już sama ocena - zarówno zdolności ludzi i ich poziomu wiedzy, jak i skuteczności w zakresie podejmowania tych działań. W przyszłości inżynierskie rozwiązania mogą stanowić tu istotną pomoc. Tak jak zmienia się funkcjonowanie człowieka w innych dziedzinach, również w tym obszarze coraz częściej człowiek otrzymuje skuteczne wsparcie dedykowanych rozwiązań technologicznych ${ }^{32}$, z którego potrafi skorzystać w celu optymalizacji swoich działań

29 Tamże.

30 „Pożar jest chemiczną reakcją spalania, która przebiega względnie wolno i w dłuższym okresie. Pojawia się, gdy zaistnieje przestrzenna i czasowa współzależność czynników warunkujących jego powstanie. Pożar ma wielorakie działanie destrukcyjne: niszczenie konstrukcji obiektów, spalanie materiałów lub ich niszczenie przez strumień ciepła generowany w różnych fazach jego rozwoju. Ponadto może wpływać na ludzi zarówno przez bezpośrednie oddziaływanie płomienia na organizm, jak i termiczną radiację, względnie przez toksyczne oddziaływanie produktów rozkładu termicznego i spalania” Źródło: M. Pofit-Szczepańska, Wybrane zagadnienia..., dz. cyt., s. 14.

31 „Zagrożenia dla życia i zdrowia ludzi, które mogą występować podczas pożarów to w szczególności: toksyczne produkty spalania, temperatura i promieniowanie cieplne, niedobór tlenu, ograniczona widoczność, uszkodzenie konstrukcji obiektu lub jego elementów, hałas”. Źródło: W. Klapsa, S. Suchecki, D. Bąk, A. Dziechciarz, Czynniki narażenia podczas pożarów, w: Czerwona księga pożarów, t. 1, P. Guzewski, D. Wróblewski, D. Małozięć (red.), Wydawnictwo CNBOP-PIB, Józefów 2014, s. 528-540.

32 Przykładem może być aplikacja Ratownik - kwalifikowana pierwsza pomoc w twoim telefonie. „Ratownik to aplikacja zawierająca obowiązujące od 12.02.2013 r. procedury ratownicze z zakresu kwalifikowanej pierwszej pomocy dla jednostek KSRG. Została stworzona z myślą o zapewnieniu wszystkim zainteresowanym szerokiego dostępu do aktualizowanej na bieżąco i poszerzanej bazy wiedzy z zakresu ratownictwa medycznego z wykorzystaniem współczesnych możliwości technicznych”. Źródło: Aplikacja Ratownik, http://aplikacja-ratownik.pl/ [dostęp: 2.02.2020]. 


\subsection{Wnioski}

Inżynieria bezpieczeństwa ${ }^{33}$ odnosi się do planowania, projektowania, budowania, organizowania i funkcjonowania systemów związanych z koniecznością przeciwdziałania zagrożeniom ogółu ludzkości, środowiska naturalnego oraz dóbr cywilizacyjnych. Inżynieria bezpieczeństwa pożarowego znajduje coraz szersze zastosowanie w wypracowywaniu praktycznych rozwiązań na rzecz bezpieczeństwa pożarowego. W ochronie przeciwpożarowej szczególnie cenna jest w obszarze rozwiązań prewencyjnych - czynnych i biernych zabezpieczeń przeciwpożarowych. Szersze niż dotychczas zastosowanie rozwiązań inżynierskich można przewidywać w najbliższym czasie głównie dla optymalizacji działań ratowniczych, a także profilaktyki i edukacji społecznej. Natomiast inżynieria środowiska ${ }^{34}$, górnictwo i energetyka, jako dyscyplina nauki, obejmuje przedsięwzięcia ukierunkowane na zachowanie stanu równowagi, samoregeneracji i samooczyszczania oraz odtworzenia środowiska przyrodniczego, dostarcza naukowych podstaw racjonalnego gospodarowania zasobami przyrody oraz prognozowania, oceny, zapobiegania i naprawy negatywnych skutków niszczenia tych zasobów.

W tak definiowanej inżynierii bezpieczeństwa i inżynierii środowiska wskazać można wspólne obszary i cele ochronne. W obu przypadkach rozwiązania inżynierskie mają służyć planowaniu, zapobieganiu i skutecznej ochronie środowiska przed określonymi zagrożeniami.

Analiza wybranych pozycji literatury przedmiotu ${ }^{35}$ pod kątem stosowania

33 A. Mizerski, dz. cyt.

34 D. Lipińska, dz. cyt., s. 13.

35 Czerwona księga pożarów, P. Guzewski, D. Wróblewski, D. Małozięć (red.), Wydawnictwo CNBOP-PIB, Józefów 2014. D. M. McGrail, Firefighting Operations In High-Rise And Standpipe-Equipped Buildings, Fire Engineering Books \& Videos, Tulsa 2007.

G. Corbett, Fire Engineering’s Handbook for Firefighter I \& II, Fire Engineering Books \& Videos, Tulsa 2007.

G. Corbett, Fire Engineering's Skill Drills for Firefighter I and II, Fire Engineering Books \& Videos, Tulsa 2009.

G. Corbett, Fire Engineering's Skill Drills for Firefighter I and II. Addendum Materials for 2012, Fire Engineering Books \& Videos, Tulsa 2012.

F. M. Stowell, Essentials of Fire Fighting and Fire Department Operations, Wyd. 6, Oklahoma State University, New Jersey 2013.

K. Szczerba, Bezpieczny dom, Wydawnictwo CNBOP PIB, Józefów 2012.

NFPA 101: Life Safety Code, 2012 Edition, National Fire Protection Association 2011.

NFPA 1620 Standard for Pre-Incident Planning 2010 Edition, National Fire Protection Association 2011.

NFPA 1710 Standard for the Organization and Development of Fire Suppression Operations, and Special Operations to the Public by Career Fire Departments 2010 Edition, National Fire Protection Association 2009,

NFPA 1720 Standard for the Organization and Deployment of, Fire Suppression Operations, Emergency Medial Operations, and Special Operations to the Public by Volunteer Fire Departments, National Fire Protection Association 2013. NFPA 1561 Standard on Emergency Services Incident Management System and Command Safety 2014 Edition, National Fire Protection Association 2014.

NFPA 5000®: Building Construction and Safety Code, 2012 Edition, National Fire Protection Association.

R. Kolomny, R. Hoff, Firefighter Rescue \& Survival, PennWell Corporation, Tulsa, Oklahoma USA 2003, s. 15-17.

T. Sawicki, B. Sygit, P. Guzewski, Problemy ustalania przyczyn pożarów - Istota przestępczego pożaru w świetle orzecz- 
metod inżynierskich dowodzi skali i wagi problemu zagrożenia pożarowego na chwilę obecną, pozwala również na formułowanie wniosków dotyczących przyszłości. Istnieje także potrzeba dogłębnego badania i ciągłego doskonalenia ochrony przeciwpożarowej. Rosnące potrzeby w tym zakresie uzasadniają stosowanie nowych rozwiązań. Rozwój techniki i technologii stwarza z jednej strony nowe możliwości, ale z drugiej prowadzi do ewolucji znanych i powstawania nowych zagrożeń. Dlatego też coraz bardziej dostrzegalna jest potrzeba nie tylko inżynierskiego, ale i naukowego podejścia do zagadnień bezpieczeństwa pożarowego. W praktyce nauka coraz częściej okazuje się konieczna, użyteczna, czy wręcz konieczna do rozwiązywania konkretnych problemów ochrony życia, zdrowia, a także mienia i środowiska. Inżynieria bezpieczeństwa pożarowego, a także ocena ryzyka to coraz ważniejsze zagadnienia w dyskusji i praktyce badań nad bezpieczeństwem i jego projektowaniem. Przy tym niezmienne pozostają zidentyfikowane potrzeby i kierunki działań w celu zapewnienia wyższego poziomu bezpieczeństwa pożarowego:

1. Należy rozważać poziom dopuszczalnego i akceptowalnego ryzyka (osobistego i społecznego).

2. Istnieje potrzeba precyzyjnego określania i uzgadniania obszarów i celów zapewnienia bezpieczeństwa pożarowego. Konieczne jest lepsze zrozumienie tego, jak pożar powstaje, rozwija się i rozprzestrzenia ${ }^{36}$ oraz uwzględnienie zmieniającego się zagrożenia i powstawania nowych.

3. Ważne jest zrozumienie, w jaki sposób różne techniczne środki zabezpieczeń przeciwpożarowych (bierne i czynne) mogą łagodzić, ograniczyć potencjalne straty pożarowe lub im zapobiegać.

4. Konieczne jest permanentne poznawanie, jak ludzie aktualnie reagują w sytuacji pożaru.

5. Istnieje potrzeba stosowania wiarygodnych narzędzi i metod dotyczących określania powyższych czynników.

6. Należy rozważyć oddziaływanie finansowe decyzji z zakresu bezpieczeństwa pożarowego, a także ich bieżącą optymalizację według zasady koszt - efekt. ${ }^{37}$

nictwa sądowego. Zeszyt 2, Problemy Ustalania Przyczyn Pożarów, Polskie Towarzystwo Dochodzeń Popożarowych, Poznań 2013.

36 Jest to konieczne w związku z zachodzącymi zmianami aranżacji wyposażania obiektów budowlanych. Gromadzenie innych niż w przeszłości ilości i rodzajów materiałów palnych ma istotny wpływ na rozwój pożaru.

37 Wnioski w referacie - J. Zboina, T. Kiełbasa, Inżynieria bezpieczeństwa pożarowego, materiały z konferencji naukowej Ochrona przeciwpożarowa w systemie bezpieczeństwa państwa, Józefów 2013. 
Przywołane powyżej zagrożenia dla człowieka podczas pożaru odnoszą się w szczególności do wymagań dla obiektów budowlanych. Wymagania podstawowe odnoszące się do obiektów budowlanych (w tym te dotyczące bezpieczeństwa pożarowego) wynikają z Rozporządzenia Parlamentu Europejskiego i Radu (UE) nr 305/2011 z dnia 9 marca 2011 r. ustanawiającego zharmonizowane warunki wprowadzania do obrotu wyrobów budowlanych i uchylające dyrektywę Rady 89/106/EWG.

Zgodnie z tą regulacją obiekty budowlane muszą być zaprojektowane i wykonane w taki sposób, aby w przypadku powstania pożaru:

- nośność konstrukcji została zachowana przez określony czas,

- powstawanie i rozprzestrzenianie się ognia i dymu w obiektach budowlanych było ograniczone,

- rozprzestrzenianie się ognia na sąsiednie obiekty budowlane było ograniczone,

- osoby znajdujące się wewnątrz mogły opuścić obiekt budowlany lub być uratowane w inny sposób,

- uwzględnione było bezpieczeństwo ekip ratowniczych ${ }^{38}$.

Wymogi te stanowią podstawę w działaniach na rzecz ochrony przeciwpożarowej i realizacji jej celów, tj. ochrony życia i zdrowia, mienia, środowiska oraz zapewnienia ciągłości funkcjonowania. Wraz z innymi przepisami krajowymi w randze ustaw i rozporządzeń regulacje te tworzą w Polsce system ${ }^{39}$ prawny wymagań i nakazów, w którym - w opinii autora - w najbliższej przyszłości będzie należało uwzględnić, w szerszym zakresie niż obecnie, rozwiązania inżynierii bezpieczeństwa pożarowego. Do tego potrzebne jest jednak ugruntowanie się rozumienia, zakresu i znaczenia inżynierii bezpieczeństwa pożarowego.

38 J. Zboina, K. Brudnicka, G. Mroczko, Bezpieczeństwo pożarowe obiektów budowlanych, w: Bezpieczeństwo na morzu, lądzie i w powietrzu w XXI wieku, J. Zboina (red.), Wydawnictwo CNBOP-PIB, Józefów 2014, s. 94; J. Zboina, T. Kiełbasa, Inżynieria bezpieczeństwa pożarowego, dz. cyt.

39 T. Kotarbiński, Traktat o dobrej robocie, Wydawnictwo Polskiej Akademii Nauk, Wrocław 1982, s. 18-23. 


\section{Wdrażanie nowych technologii i rozwiązań}

W niniejszym rozdziale na podstawie prowadzonych badań, prac projektowych, doświadczeń i pracy zawodowej, a także krytycznej analizy literatury przedmiotu przedstawiono wybrane rozważania i wnioski dotyczące możliwości i warunków koniecznych do wprowadzania nowych technologii i rozwiązań przeznaczonych do zastosowania w obszarze bezpieczeństwa, z szczególnym uwzględnieniem bezpieczeństwa pożarowego. Intencją autora w tym rozdziale było, aby z jednej strony przedstawić te zagadnienia w sposób wyczerpujący, z drugiej zaś - z ograniczeniem do najistotniejszych aspektów i niezbyt obszernie. Taka forma ułatwia czytelnikowi analizę i pozyskanie praktycznych informacji. Jednocześnie przyjąć należy, iż publikacja ta nie wyczerpuje tematu, a jedynie stanowi pewien głos w dyskusji dotyczącej nowych rozwiązań i możliwości ich stosowania w obszarze szeroko rozumianego bezpieczeństwa.

\subsection{Podstawy formalne}

Do kluczowych uwarunkowań formalnych niezbędnych do wdrażania nowych rozwiązań (zarówno systemów/zestawów, jak i pojedynczych wyrobów) należy zaliczyć przede wszystkim prawo. Może ono sprzyjać innowacjom (wówczas ułatwia stosowanie nowych rozwiązań), być neutralne lub uniemożliwiać ich wdrożenie. Pozornie tylko neutralną sytuacją jest brak takich regulacji. Nie jest to jednak korzystne, gdy wdrożenia dotyczyć mają obszaru bezpieczeństwa. Punktem odniesienia bowiem do wymagań i warunków stosowania nowych i innowacyjnych wyrobów, systemów czy rozwiązań są bardzo często wyroby już użytkowane w tym obszarze od dawna, dla których funkcjonują i są egzekwowane regulacje i wymagania. Mają one postać szczegółowych zapisów prawnych i wymagań technicznych (opisanych odpowiednio w normach wyrobów, przywołanych dokumentach lub bezpośrednio w przepisach prawa - szerzej zagadnienia wymagań dla wyrobów opisano między innymi w specjalistycznych publikacjach ${ }^{1}$ ). Ponadto

1 Zob. na przykład: Standard CNBOP-PIB 0001:2019 Wprowadzenie do obrotu i użytkowania wyrobów stosowanych w ochronie przeciwpożarowej: „Czytelnik - dzięki lekturze niniejszego standardu - może dowiedzieć się, jakie wymagania (dotyczące zagadnień bezpieczeństwa pożarowego) powinny spełniać wyroby oraz jakie dokumenty i oznakowanie potwierdzają spełnienie stawianych im wymagań - zarówno przez prawo krajowe, jak i europejskie. 


\section{Wdrażanie nowych technologii i rozwiązań | Podstawy formalne}

w niektórych państwach w Europie i na świecie ważną rolę w obszarze bezpieczeństwa pożarowego odgrywają również dodatkowe, pozaprawne wymagania branżowe, a także te stawiane przez towarzystwa ubezpieczeniowe. W opinii wielu ekspertów, a także autora tej monografii, najlepszą dla rozwoju innowacji jest sytuacja, gdy funkcjonuje właściwe otoczenie prawne i praktyka sprzyjająca wdrażaniu nowych wyrobów, systemów i rozwiązań. Najbardziej niekorzystny formalnie stan zachodzi, gdy - poza brakiem ułatwień - funkcjonują skuteczne bariery formalne i nieformalne, które uniemożliwiają tworzenie i wdrażanie nowych rozwiązań, mimo zapotrzebowania na rynku. Aktualnie wiele mówi się o innowacjach ${ }^{2}$, podejmowane są w tym zakresie różnorodne działania ${ }^{3}$. Najprościej rzecz ujmując, poprzez różnorodne działania poszukuje się właśnie takich warunków dla innowacji, które będą sprzyjały ich tworzeniu i - co najistotniejsze - wdrażaniu.

Regulacje w Polsce w obszarze stosowania wyrobów na rzecz bezpieczeństwa pożarowego nie odbiegają w istotny sposób od tych funkcjonujących w innych państwach Unii Europejskiej. Dla części tego typu wyrobów obowiązują wymagania odpowiednio prawa Unii Europejskiej oraz krajowego. Regulacjami tymi nie są objęte wszystkie wyroby stosowane na rzecz ochrony przeciwpożarowej, a jedynie te najistotniejsze dla bezpieczeństwa pożarowego obiektów budowalnych i prowadzenia działań ratowniczo-gaśniczych przez straż pożarną. W Polsce funkcjonują aktualnie dwa ważne, ustawowe obszary regulacji dla zapewnienia odpowiednich właściwości stosowanych wyrobów, które mają szczególne znaczenie dla bezpieczeństwa pożarowego obiektów budowlanych, ich użytkowników,

Informacje te pozwolą wybrać produkty spełniające określone prawem wymagania, a co za tym idzie, bezpieczne, niezawodne oraz funkcjonalne. Zastosowanie w obiektach budowlanych wyrobów spełniających określone wymagania jest niezwykle istotne z punktu widzenia zapewnienia bezpieczeństwa użytkownikom i ratownikom. Niniejszy standard skierowany jest do wszystkich osób zainteresowanych zapewnieniem bezpieczeństwa pożarowego i właściwych warunków ochrony przeciwpożarowej”. Źródło: I. Bąbik, D. Bąk, K. Jankowska, I. Majka, Standard CNBOP-PIB 0001:2019, Wprowadzenie do obrotu i użytkowania wyrobów stosowanych w ochronie przeciwpożarowej, Wyd. 6, Wydawnictwo CNBOP-PIB, Józefów 2019.

2 Wśród wielu dostępnych definicji innowacji (słowa w ocenie autora niekiedy nadużywanego w potocznym zastosowaniu) tą, która wyczerpuje właściwy zakres i rozumienie pojęcia, wydaje się następująca: „Przez innowację rozumie się wprowadzenie do praktyki w przedsiębiorstwie, organizacji, ... itp. nowego lub znacząco ulepszonego rozwiązania w odniesieniu do produktu (towaru lub usługi), procesu, marketingu lub organizacji. Istotą innowacji jest właściwe wdrożenie nowości do praktyki”. Źródło: Za R. Kasprzakiem, Fundusze Unijne, szansa dla małych i średnich przedsiębiorstw, dz. cyt., s. 45.

3 Przykłady działań na rzecz innowacji:

- tworzenie i wdrażanie strategii innowacyjności - dla produktów, usług, organizacji działania firm;

- wsparcie dla innowacji - tworzenie dedykowanych rozwiązań prawnych, w tym oceny zgodności wyrobów innowacyjnych;

- finasowanie innowacji - programy i projekty finansowane ze środków krajowych i UE (np. bony na innowacje). 


\section{Wdrażanie nowych technologii i rozwiązań | Podstawy formalne}

a także bezpieczeństwa ratowników i ratowanych podczas prowadzenia działań ratowniczo-gaśniczych.

Pierwszy z nich to certyfikacja wybranych wyrobów budowlanych stosowanych w ochronie przeciwpożarowej. Podstawy dla systemów oceny zgodności tej grupy wyrobów określają odpowiednio przepisy UE ${ }^{4}$ i krajowe ${ }^{5}$. Dodatkowe, krajowe wymagania dla wybranych wyrobów budowlanych - przede wszystkim dla sprzętu i wyposażenia straży pożarnej - postawione zostały w krajowych przepisach dotyczących dopuszczeń6.

Główne cele stosowania oceny zgodności dla tych wyrobów to:

- potwierdzenie oczekiwanych parametrów wyrobów, zestawów, technicznych systemów zabezpieczeń (wynikających z zakresu stosowania),

- możliwość skutecznej realizacji celów ochronnych w zakresie ochrony przeciwpożarowej (zdrowie, życie, mienie, ciągłość działania),

- możliwość skutecznego prowadzenia działań ratowniczych, zapewnienie bezpieczeństwa ratowanych i ratowników.

Niezależnie od wspomnianych regulacji w odniesieniu do wyrobów budowlanych używanych w Polsce zastosowanie mają przepisy art. 5.3 i 10 ustawy o wyrobach budowalnych dotyczące wprowadzania do stosowania wyrobów zastosowanych w innym państwie UE i jednostkowego ich stosowania.

Wskazane powyżej systemy oceny zgodności okresowo podlegają aktualizacjom. U podstaw zmian leży ewolucja istniejących oraz pojawianie się nowych potrzeb i wyzwań, a także ocena funkcjonujących już regulacji i wnioski z niej wynikające. Inną przyczyną takich nowelizacji jest rozwój techniki i technologii, pojawianie się nowych rozwiązań. Są to ważne sposobności do doskonalenia bezpieczeństwa pożarowego w obszarze stosowania technicznych zabezpieczeń przeciwpożarowych, jak również sprzętu i wyposażenia straży pożarnej.

4 Rozporządzenie Parlamentu Europejskiego i Rady nr 305/2011 z dnia 9 marca 2011 r. ustanawiające zharmonizowane warunki wprowadzania do obrotu wyrobów budowlanych i uchylające dyrektywę Rady 89/106/EWG (Dz. Urz. UE 88 z 04.04.2011, s. 5-43).

5 Ustawa z dnia 16 kwietnia 2004 r. o wyrobach budowlanych (Dz.U. Nr 92 poz. 881 z późn. zm.) wraz z aktami wykonawczymi w formie rozporządzeń.

6 Ustawa z dnia 24 sierpnia 1991 r. o ochronie przeciwpożarowej (tekst jedn.: Dz. U. 2020 poz. 961).

Rozporządzenie Ministra Spraw Wewnętrznych i Administracji z dnia 20 czerwca 2007 r. w sprawie wykazu wyrobów służących zapewnieniu bezpieczeństwa publicznego lub ochronie zdrowia i życia oraz mienia, a także zasad wydawania dopuszczenia tych wyrobów do użytkowania (Dz. U. Nr 143, poz. 1002);

Rozporządzenie Ministra Spraw Wewnętrznych i Administracji z dnia 27 kwietnia 2010 r. zmieniające rozporządzenie w sprawie wykazu wyrobów służących zapewnieniu bezpieczeństwa publicznego lub ochronie zdrowia i życia oraz mienia, a także zasad wydawania dopuszczenia tych wyrobów do użytkowania (Dz. U. Nr 85, poz. 553 z późn. zm.). 


\section{Wdrażanie nowych technologii i rozwiązań | Podstawy formalne}

Wymagania dla stosowanych wyrobów, rozwiązań czy systemów to absolutne minimum w systemie bezpieczeństwa (w praktyce zawodowej autora często określa się je jako fundament - w przenośnym znaczeniu - do dalszego „budowania”). Od deklarowanych w trakcie oceny parametrów, ich zachowania w okresie eksploatacji, niezawodności, funkcjonalności, ergonomii, kompatybilności i dostosowania do bieżących potrzeb stosowanych wyrobów i systemów zależy odpowiednio zdrowie i życie ratowanych i ratowników, a także bezpieczeństwo pożarowe w obiektach budowalnych w aspekcie ochrony jego użytkowników i ich mienia oraz zapewnienia ciągłości działania. Wyroby budowlane i ich właściwości (określane zgodnie z art. 8 ustawy o wyrobach budowalnych jako zasadnicze charakterystyki) mają wpływ na spełnienie podstawowych wymagań stawianych obiektom budowlanym, zgodnie z zamierzonym zastosowaniem tego wyrobu. Dlatego zasadne jest określanie wskazanych wymagań dla wyrobów jako minimum w zakresie zapewnienia bezpieczeństwa pożarowego. Ocena zgodności jest jednym z ważniejszych i nielicznych narzędzi, które mają bezpośredni i tak duży wpływ na cele ochronne skuteczną ochronę zdrowia, życia, a także mienia i zapewnienie ciągłości działania.

Ocena zgodności była i jest systematycznie racjonalizowana. Główne kroki w tym zakresie to nowelizacje przepisów stanowiących podstawę certyfikacji i dopuszczeń wyrobów. Ich zakres najczęściej dotyczy opisanych systemów oceny zgodności, szczegółowych czynności w samym procesie, a także aktualizacji wymagań czy samych grup wyrobów podlegających regulacji przez te przepisy. Inną przyczyną nowelizacji jest dostosowanie przepisów do prawa UE.

W przywołanych rozwiązaniach prawnych dotyczących ochrony przeciwpożarowej w Polsce przewidziano te przeznaczone dla nowych wyrobów - opracowywanie krajowych ocen technicznych i dokonywanie na ich podstawie oceny zgodności tych wyrobów ${ }^{7}$. To rozwiązanie sprzyja tworzeniu i wdrażaniu nowych rozwiązań w zakresie wprowadzanych na rynek wyrobów, ich zestawów i systemów spełniających definicję wyrobu budowlanego ${ }^{8}$. Nie wszystkie z systemów

$7 \quad$ Art. 9 ustawy z dnia 16 kwietnia 2004 r. o wyrobach budowlanych (Dz. U. 2004 nr 92 poz. 881 z późn. zm.),

Rozporządzenie Ministra Infrastruktury i Budownictwa z dnia 17 listopada 2016 r. w sprawie krajowych ocen technicznych (Dz. U. 2016 poz. 1968 z poźn. zm.).

Krajową ocenę techniczną wydaje się dla wyrobu budowlanego:

1) nieobjętego zakresem przedmiotowym Polskiej Normy wyrobu, albo

2) jeżeli w odniesieniu do co najmniej jednej zasadniczej charakterystyki wyrobu budowlanego metoda oceny przewidziana w Polskiej Normie wyrobu nie jest właściwa, albo

3) jeżeli Polska Norma wyrobu nie przewiduje metody oceny w odniesieniu do co najmniej jednej zasadniczej charakterystyki wyrobu budowlanego.

8 Rozporządzenie Parlamentu Europejskiego i Rady (UE) nr 305/2011 z dnia 9 marca 2011 r. ustanawiające zharmonizowane warunki wprowadzania do obrotu wyrobów budowlanych i uchylające dyrektywę Rady 89/106/EW 
oceny zgodności przewidują rozwiązania formalne dedykowane dla wyrobów nowych. Przywołane powyżej przykłady regulacji z rynku polskiego dowodzą słuszności tezy, iż innowacje wymagają określonego uwarunkowania, w tym otoczenia formalnego. Uwarunkowania sprzyjające tworzeniu i wdrażaniu9 innowacji, które skutecznie usuwają lub minimalizują potencjalne bariery, to pierwszy z warunków koniecznych dla działalności wdrożeniowej.

Rozwiązaniom prawnym dotyczącym wdrażania nowych wyrobów i rozwiązań towarzyszyć musi zdolność do tworzenia technicznych dokumentów odniesienia, stanowiących podstawę $\mathrm{w}$ procesie ich oceny zgodności. Takie uwarunkowania formalne i dokumenty opisujące wymagania techniczne pozwalają na wdrażanie w praktyce wyrobów lub rozwiązań i budowania koniecznego zaufania do nich.

\subsection{Zaufanie do wyrobów i rozwiązań}

Zaufanie do wyrobów i rozwiązań, w tym w odniesieniu do ich deklarowanych parametrów, skuteczności działania, niezawodności, ergonomii i bezpieczeństwa jest podstawowym warunkiem decydującym o ich stosowaniu. Jest to szczególnie ważne w przypadku produktów służących właśnie bezpieczeństwu, między innymi czynnych i biernych zabezpieczeń przeciwpożarowych. Posiadają one określone, dedykowane właściwości pozwalające projektować w ochronie przeciwpożarowej zakładane funkcje i funkcjonalności. W zakresie ochrony przeciwpożarowej wspomniane zaufanie budowane jest głównie poprzez potwierdzenie przez producenta deklarowanych charakterystyk wyrobów. Odbywa się to w procesie oceny zgodności ${ }^{10}$.

Budowanie przeświadczenia o niezawodności stosowanych wyrobów i jakości usług, takich jak projektowanie, instalowanie i konserwacja technicznych systemów zabezpieczeń przeciwpożarowy jest zadaniem trudnym, wymagającym ciągłych i różnorodnych działań w każdym państwie. Cel ten osiągany jest poprzez ustalanie wymagań formalnych (prawnych), branżowych, a także dodatkowych

(Dz.Urz.UE88,4.4.2011,5-43).Wyrób budowlanyoznaczakażdywyróblubzestawwyprodukowanyiwprowadzonydo obrotu w celu trwałego wbudowania w obiektach budowlanych lub ich częściach, którego właściwości wpływają na właściwości użytkowe obiektów budowlanych w stosunku do podstawowych wymagań dotyczących obiektów budowlanych.

9 Przykładem rozwiązań dedykowanych innowacjom jest dobrowolne i bezpłatne testowanie wyrobów innowacyjnych w jednostkach Państwowej Straży Pożarnej w Polsce. To specjalistyczna procedura, zgodnie z którą nowy wyrób po poddaniu go przez CNBOP-PIB weryfikacji bezpieczeństwa na podstawie dokumentów producenta testowany jest przez strażaków w jednostkach ratowniczo-gaśniczych. Ustala się dla takiego wyrobu indywidualny program testowania - sprawdzenia podczas ćwiczeń przez ratowników. Procedura testowania jest prowadzona przez CNBOP-PIB, które na podstawie otrzymanych w jej toku wyników opracowuje opinię/rekomendacje, zawierająca opis produktu, zakres jego zamierzonego zastosowania, rezultaty oceny. Więcej informacji: patrz załącznik 1.

Zob. Definicje i skróty niniejszej publikacji, pojęcie - ocena zgodności. 
wymagań towarzystw ubezpieczeniowych. Wyzwanie dotyczy zarówno zapewnienia właściwości wyrobów wykorzystywanych w ochronie przeciwpożarowej, tj. sprzętu i wyposażenia straży pożarnej oraz czynnych i biernych zabezpieczeń przeciwpożarowych stosowanych w obiektach budowlanych, jak i kształtowania zaufania do tych wyrobów zastosowanych w obiektach budowlanych w określonym celu. Ocena zgodności ${ }^{11}$ i procesy dopuszczenia wyrobów używanych w ochronie przeciwpożarowej stanowią elementy polityki bezpieczeństwa pożarowego każdego państwa. Procesy dopuszczenia wyrobów wprowadzanych do użytkowania i wykorzystywanych przez jednostki ochrony przeciwpożarowej są ważnym narzędziem ${ }^{12}$ zapewniania niezbędnego bezpieczeństwa ratownikom i ratowanym, a także bezpieczeństwa pożarowego w obiektach budowlanych. Kolejnym wyzwaniem jest właściwe funkcjonowanie tego systemu i jego dostosowywanie do zmieniających się potrzeb. Najlepsze wyroby, ale niepoprawnie zaprojektowane, zamontowane i eksploatowane, nie pozwalają osiągnąć celów ochrony przeciwpożarowej. Dlatego istotną kwestią jest zapewnienie właściwej jakości świadczonych usług w zakresie ochrony przeciwpożarowej. W Polsce certyfikacja tych usług jest dobrowolna. Wyroby są podstawą zapewnienia bezpieczeństwa pożarowego w obiektach budowlanych - ważne jest ich właściwe projektowanie, instalowanie, konserwowanie i eksploatowanie. Dlatego podejmuje

11 Ocena zgodności wyrobów, które są wprowadzane do użytkowania w jednostkach ochrony przeciwpożarowej i wykorzystywane przez te jednostki do prowadzenia działań ratowniczych, wraz z certyfikacją europejską i krajową wyrobów budowlanych mają podstawy prawne w ustawie o ochronie przeciwpożarowej i ustawie z dnia 16 kwietnia 2004 r. o wyrobach budowlanych (Dz. U. Nr 92, poz. 881 z późn. zm.). Wraz z aktami wykonawczymi do nich przepisy te tworzą podstawy do certyfikacji i prowadzenia procesów dopuszczeń tych wyrobów.

12 Certyfikacja i procesy dopuszczenia wyrobów są prowadzone dla wskazanego sprzętu i wyposażenia straży pożarnej, a także dla wyrobów stosowanych w obiektach budowlanych. Można wyróżnić systemy certyfikacji i dopuszczeń wyrobów stosowanych w ochronie przeciwpożarowej. Wymagania dotyczące tych wyrobów znajdują się w normach wyrobów, aprobatach technicznych, krajowych ocenach technicznych, wymaganiach techniczno-użytkowych (dla dopuszczeń). Poświadczeniem spełnienia wymagań są certyfikaty i świadectwa dopuszczenia. W zakresie nieregulowanym przydatne są również dobrowolne rekomendacje i opinie techniczne - zarówno te dotyczące wyrobów, jak i warunków ich stosowania. Ocena zgodności oraz dopuszczenia i wymagania dla wyrobów podlegają zmianom i nowelizacji. Krajowe dopuszczenia wyrobów są powiązane z innymi przepisami w zakresie oceny zgodności i mają kluczowe znaczenie dla ochrony przeciwpożarowej, a tym samym dla bezpieczeństwa publicznego. Dopuszczenia wyrobów do stosowania w ochronie przeciwpożarowej są sprawdzonym rozwiązaniem, które funkcjonuje w Polsce od blisko 50 lat. Zmieniające się zagrożenia oraz zakres działalności jednostek ochrony przeciwpożarowej powodują, że pojawiają się nowe zadania i wymagania dotyczące ocen zgodności i dopuszczeń. Ciągłe zmiany dotyczące sprzętu dla straży pożarnej oraz wyrobów budowlanych wymuszają stałą aktualizację przepisów prawa i dokumentów normatywnych. Dlatego bieżącemu procesowi monitorowania, zbierania propozycji i uwag w celu przygotowania nowelizacji podlegają wymagania techniczno-użytkowe dla wyrobów dopuszczanych. W Polsce dla wyrobów wykorzystywanych w obszarze ochrony przeciwpożarowej formułuje się nie tylko wymagania podstawowe. Są też dodatkowe wymagania techniczno-użytkowe dla sprzętu i wyposażenia staży pożarnej, a także dla wybranych wyrobów budowlanych stosowanych na rzecz ochrony przeciwpożarowej w obiektach budowlanych. Obowiązek spełnienia wymagań podstawowych i dodatkowych służy zapewnieniu bezpieczeństwa ratowanych i ratowników oraz bezpieczeństwa pożarowego w obiektach budowlanych. 
się działania oraz inicjatywy, których celem jest lepsze niż obecnie zapewnienie jakości świadczonych usług w zakresie ochrony przeciwpożarowej, aby zaufanie do wyrobów i technicznych systemów zabezpieczeń przeciwpożarowych, a także sprzętu i wyposażenia straży pożarnej było możliwie najwyższe.

\subsection{Ekosystem dla innowacji}

Dostępność nowych technologii, wyrobów, systemów i rozwiązań stwarza niespotykane dotąd możliwości. Nowa oferta jest często odpowiedzią producentów i dostawców na dostrzeżone potrzeby w branży. Innowacji nie można po prostu zaplanować. Wiele podmiotów próbuje „zorganizować” innowacje i nadać im wymiar procesowy. Takie działania najczęściej kończą się jednak niepowodzeniem, ponieważ brakuje określonych warunków do ich tworzenia. Jak twierdzi D. Ludke w publikacji pt. Innowacja. Jak ją zrozumieć?, do kreowania innowacji potrzebny jest przyjazny im ekosystem. W uzupełnieniu do tego stwierdzenia można zauważyć, że gdyby to było tak proste, to już samo posiadanie kapitału czy zasobów wystarczałoby do tworzenia innowacyjnych produktów, usług czy rozwiązań i wdrażania ich choćby w tak ważnym obszarze jak bezpieczeństwo pożarowe. Innowacyjność bowiem to pewien szczególny sposób postrzegania i myślenia, jak twierdzi Z. Skalska w artykule Przestańcie mówić o innowacji! Autorka przekonuje, że w procesie innowacji najważniejsi są liderzy. Dla innowacji ważne jest zrozumienie, a może raczej przewidzenie tego, jak zmienia się życie pod względem technologii oraz potrzeb i wyzwań z tym związanych. Według autorki systematycznie myśląc o rozwoju i przyszłości, tworząc i analizując różne scenariusze, zwiększa się szansę na zidentyfikowanie trendów wyznaczających kierunki nadchodzących zmian. Innowacje nierozerwalnie wiążą się z tym, co nieznane. Mimo że przyszłości nie da się w pełni zaplanować, można się do niej przygotować. W pewnym zakresie da się przewidzieć, jakie technologie znajdą zastosowanie u przyszłych pokoleń - pod warunkiem, że będzie się bacznie obserwować, analizować i badać zmiany dzisiejszych przyzwyczajeń, potrzeb, wyzwań i zagrożeń oraz wyciągać z tych faktów wnioski. Taki ekosystem jest poszukiwany; podejmuje się także próby tworzenia warunków dla innowacji - są to konkretne działania realizowane przez różne podmioty funkcjonujące w obszarze bezpieczeństwa pożarowego. Pojawiają się również liderzy działań, zarówno w obszarze projektowania oraz wdrażania nowych produktów i rozwiązań, jak i w zakresie taktyki prowadzenia działań ratowniczych, a także samego implementowania nowych technologii i innowacji w celu zapewnienia bezpieczeństwa ratowanym, ratownikom, obiektom budowlanym, ochrony mienia, procesów i zapewnienia ciągłości działania. 
Przykładem elementu ekosystemu dedykowanego innowacjom, z jego liderami i wdrożoną już praktyką jest - przywołana wcześniej - procedura testowania wyrobów innowacyjnych realizowana w jednostkach ratowniczo-gaśniczych Państwowej Straży Pożarnej. Cele, założenia i wyniki tych prac, a także korzyści uzyskiwane z prowadzonego w ten sposób dialogu pomiędzy użytkownikami wyrobów a ich producentami przedstawiano w odrębnych publikacjach ${ }^{13}$. Przywołana procedura (program testowania ${ }^{14}$ ) pozwala potencjalnemu użytkownikowi (ratownikom) zapoznać się z nowym wyrobem/zestawem/systemem i na tej podstawie dokonać jego oceny pod względem użytkowym, ergonomicznym oraz z punktu widzenia oczekiwanych funkcjonalności i parametrów. Z kolei producent może w proceduralny sposób (ale z formalnościami ograniczonymi do minimum) poznać opinię, uwagi, zalecenia czy potrzeby ratowników w odniesieniu do swojego produktu. To przykład działania istotnie wspierającego wdrażanie innowacyjnych rozwiązań i produktów na rzecz bezpieczeństwa pożarowego, a także tworzenia dodatkowego elementu ekosystemu dla innowacji.

Aby tworzyć i wdrażać innowacje pozwalające na poprawę bezpieczeństwa pożarowego oraz doskonalenie jego systemu, niezbędne wydają się także - poza wspomnianą już otwartością i gotowością na te innowacje - określone narzędzia. Jednym z nich, dość oryginalnym (niestosowanym dziś nadal powszechnie), jest właśnie testowanie wyrobów innowacyjnych w PSP w Polsce. Kolejne to przywoływane już wcześniej podstawy formalne czy też badania i projekty w ramach konkursów w zakresie obronności i bezpieczeństwa oraz projekty poświęcone rozwojowi przedsiębiorczości (np. bony na innowacje), a także te finansowane przez zainteresowane podmioty komercyjne.

Prowadzone badania własne pozwalają sformułować poniższe - publikowane już wcześniej - wnioski o konieczności zarządzania innowacjami. W praktyce wdrażanie nowych rozwiązań i innowacji jest złożone. Dobry pomysł czy produkt nie jest różnoznaczny z masowym zastosowaniem, wdrożeniem czy komercjalizacją. Dla wdrażania innowacji często duże znaczenie mają uwarunkowania

13 Zob.: B. Marcinów, J. Zboina, G. Mroczko, Sprawdzone nowości, „Przegląd Pożarniczy” 2017, 12, 31-33; J. Zboina, M. Chmiel, M. Kędzierska, M. Gołaszewska, Systemy wsparcia odbiorów i testowania wyrobów oraz rozwiąań na rzecz ochrony przeciwpożarowej, „Bezpieczeństwo i Technika Pożarnicza” 2015, 37(1), 159-169; J. Zboina, G. Mroczko, Testowanie wyrobów innowacyjnych, „Przegląd Pożarniczy” 2015, 8, s. 25.

14 Program testowania jest uzgadniany pomiędzy użytkownikiem a dostawcą czy producentem wyrobu, rozwiązania. W procesie przyjęcia wyrobu do testowania i ustalania jego programu uzyskiwana jest akceptacja KG PSP. To ważne, ponieważ już na wstępnym etapie jest podejmowana decyzja dotycząca „co najmniej wstępnego zainteresowania” wyrobem, rozwiązaniem, a także zakresem jego potencjalnego zastosowania w PSP - co ma przełożenie na program jego testowania. Są to badania - testowanie użytkowe, a nie laboratoryjne (jak w przypadku oceny zgodności tych wyrobów). 
lokalne czy krajowe. Przywoływanym przez autora przykładem wpływu uwarunkowań lokalnych czy krajowych na wdrożenie rozwiązań są strategie pożarowe ${ }^{15}$. Znalazły one swoje zastosowanie w Wielkiej Brytanii; ich idea jest ciekawa, nowoczesna i inspirująca. Jak pokazuje praktyka, wdrożenie tych strategii w warunkach polskich wymaga szczególnych, dedykowanych działań, które nie muszą przynieść efektów zbliżonych do tych, które uzyskano w Wielkiej Brytanii. W obszarze wdrażania innowacji i zarządzania nimi wskazać można ponadto inne ograniczenia, potrzeby i zagrażania. Podejmowane są próby wykorzystania na przykład Internetu rzeczy ${ }^{16} \mathrm{w}$ obszarze bezpieczeństwa. Zadawane już przez autora pytanie - Czy jest to rozwiązanie, które w najbliższej przyszłości zostanie powszechnie wykorzystane na potrzeby bezpieczeństwa pożarowego? - pozostaje wciąż aktualne. Mimo istotnego postępu, wdrożeń i nowych pomysłów to i inne pytania dotyczące „recepty” na innowacje, wdrożenie ich są dziś nadal zadawane przez badaczy, specjalistów, innowatorów i naukowców różnych branży i dyscyplin. Odpowiedzi na nie przekładają się na rozwiązania i innowacje, które zostały wdrożone i te, które pozostały tylko dobrym pomysłem ${ }^{17}$.

\subsection{Współpraca}

Współpraca jest kolejnym - ważnym, jeśli nie najważniejszym - elementem nie tylko dla innowacji, ale niemal dla każdego podejmowanego działania. W codziennej pracy autor stosuje i propaguje wśród swoich współpracowników i partnerów następującą zasadę: współpracujemy z każdym, kto chce współpracować z nami, pod warunkiem, iż współpraca ta daje wartości dodane i/lub korzyści, ale dla wszystkich współpracujących. Tylko taka forma w dotychczasowej praktyce zawodowej autora okazywała się optymalna i trwała. Sformułowanie powyższej zasady było możliwe dzięki wieloletniej pracy zawodowej przy licznych projektach, realizowanych z różnymi podmiotami - tych udanych, ale przede wszystkim nieudanych. Wymiana doświadczeń, wiedzy, wzajemna inspiracja czy różnice zdań, prowadzenie badań i ocena ich wyników, a także

15 „Podejście strategiczne oznacza uwzględnienie całokształtu uwarunkowań, które występują w analizowanym obiekcie, a mogą mieć istotny wpływ na warunki występujące w czasie pożaru. Wymaga ono holistycznego spojrzenia na ochronę przeciwpożarową i dokonania indywidualnego wyboru, które z możliwych rozwiązań może w danym przypadku zapewnić najlepsze rezultaty. Istotną kwestią jest, aby w przygotowywanej strategii pożarowej wzięte zostały pod uwagę cztery główne cele ochrony przeciwpożarowej: bezpieczeństwo życia, ochrona mienia, ciągłość produkcji i ochrona środowiska”. Źródło: D. Brzezińska, Strategie pożarowe - jak to wykorzystać w Polsce?, „Ochrona Przeciwpożarowa” 2017, 2, s. 18-19. internet-rzeczy-to-przewaga-w-kazdej-branzy/7MaSgj41 [dostęp: 20.02.2020].

17 J.Zboina, Bezpieczeństwo pożarowe, rozważania na gruncie nauki i praktyki, Wydawnictwo CNBOP-PIB, Józefów 2019, s. 112. 
walidowanie pomysłów - zarówno w obszarze działalności naukowej, jak i biznesowej - są niezwykle ważne dla tworzenia i wdrażania innowacji. Takie sieciowanie współpracy ma swoje głębokie uzasadnienie w bilansie wartości dodanych i wprost opisanych korzyści. Warto stosować tego rodzaju podejście i działania.

\section{Oferta}

Autor miał wiele razy okazję do dyskutowania na temat poszukiwań możliwie najlepszych rozwiązań ${ }^{18}$ dla współpracy jednostek naukowych i podmiotów biznesowych. W wyniku tych prac i prowadzonych badań sformułował następujące tezy i wnioski (część z nich ma zapewne jednak szersze zastosowanie):

1. Podstawą dla współpracy pomiędzy podmiotami (w relacji usługodawcy i klienta, ale i partnera z partnerem) jest dobrze zakomunikowana, przygotowana, skalkulowana i często spersonalizowana oferta ${ }^{19}$.

2. Nierzadko pomiędzy podmiotami naukowymi i biznesowymi występują istotne

18 1) Forum Bezpieczeństwa Polskiego Przemysłu Drzewnego 18-19.10.2017 Mortegi pt. Bezpieczeństwo Polskiego Przemystu organizowane przez PZUlab, J. Zboina - moderator, prowadzący i uczestnik - eksperckiego panelu dyskusyjnego Bezpieczeństwo pożarowe w procesie magazynowania.

2) Engineering Days 2017 Konferencja PZU poświęcona zagadnieniom związanym z zarządzaniem ryzykiem oraz aspektom bezpieczeństwa w przemyśle, PZU Sopot, 2-3.10.2017, J. Zboina - udział w eksperckim panelu dyskusyjnym w sesji pt. Kultura organizacja - fundament bezpiecznego przedsiębiorstwa.

3) Konferencja Naukowo-Techniczna RISK project 2016 pt. Innowacyjne rozwiąania w zarządzaniu ryzykiem $w$ przemyśle, RISK COACH LAB, DND projekt, Warszawa, 10-11.05.2016, J. Zboina - udział w moderowanym eksperckim panelu dyskusyjnym pt. Bezpieczny przemyst - od inwestycji do eksploatacji.

4) Konferencja Bezpieczeństwo wybrzeża, portów i żeglugi sesja II pt. Bezpieczeństwo wybrzeża, portów i żeglugi przy Międzynarodowych Targach Morskich BALTEXPO, Zarząd Targów Warszawskich / XVIII Międzynarodowe Targi Morskie BALTEXPO 2015, Gdańsk, 7-9.09.2015, J. Zboina - udział w eksperckim, moderowanym panelu dyskusyjnym pt. Bezpieczeństwo akwenów morskich oraz infrastruktury morskiej i nadmorskiej w kontekście zagrożeń specjalnych. 5) Konferencja UDT Nauka technika, gospodarka-doświadczenia i perspektywy rozwoju, UDT, Warszawa, 27.11.2014, J. Zboina - udział w moderowanym, eksperckim panelu dyskusyjnym (jako panelista) pt. Innowacje dla bezpieczeństwa-minimalizacja kosztów.

19 Nie zawsze oferta oznacza typową relację - biznes zamawia usługę badawczą, prowadzi ocenę zgodności itp. w jednostce naukowej. Często strony współpracują i tworzą wspólną ofertę w CNBOP-PIB. Przykładem może być: https://www.cnbop.pl/pl/szkolenia/partnerstwo, strona szkoleń CNBOP-PIB, [dostęp: 20.02.2020].

„Partnerstwo dla Edukacji o Bezpieczeństwie - Wśród wielu aktywności instytutu ważnym obszarem działalności jest sfera edukacyjna, w tym organizacja specjalistycznych szkoleń związanych z ochroną przeciwpożarową. Wychodząc naprzeciw oczekiwaniom rynku, CNBOP-PIB zainicjowało formę współpracy pod nazwą »Edukacja dla Bezpieczeństwa «, która stanowi kontynuację wcześniejszych działań w ramach Konsorcjów Naukowo-Przemysłowych. Serdecznie zapraszamy do współpracy przedsiębiorstwa, organizacje oraz instytucje. Jesteśmy otwarci na wszelkie propozycje w zakresie organizacji przedsięwzięć edukacyjnych z obszaru szeroko pojętego bezpieczeństwa powszechnego, ochrony przeciwpożarowej oraz zarządzania kryzysowego. Propozycja w ramach inicjatywy CNBOP-PIB pod nazwą "Partnerstwa dla Edukacji o Bezpieczeństwie« obejmuje: Szkolenia Specjalistyczne - przystąpienie do współpracy równoznaczne jest z podpisaniem porozumienia o partnerstwie - skutkuje to możliwością współorganizacji przedsięwzięć edukacyjnych, wygłaszania prelekcji, prezentacji oferty podczas organizowanych przez CNBOP-PIB szkoleń. Oferta skierowana jest do producentów urządzeń oraz sprzętu służącego ochronie przeciwpożarowej, firm wykonujących specjalistyczne instalacje zabezpieczające obiekty budowlane (projektanci, wykonawcy, konserwatorzy), specjalistów, rzeczoznawców ds. zabezpieczeń p.poż, firm ubezpieczeniowych. Partnerstwo dla Edukacji o Bezpieczeństwie” w 2019 r. było realizowane z 11 partnerami”. 
rozbieżności w ocenie warunków i możliwości współpracy. Należą do nich czas realizacji, zakres, cena, forma i standard komunikacji, style pracy, kultura organizacji itp. Trzeba je zidentyfikować i poszukiwać kompromisu.

3. Konieczne jest zbliżanie stanowisk i lepsze rozumienie możliwości i ograniczeń stron. Czasami współpraca nie jest jednak możliwa, to również trzeba zaakceptować.

4. Do współpracy potrzeba co najmniej dwóch partnerów - obwinianie się nawzajem nie zbuduje podstaw do współpracy; zdecydowanie skuteczniejszą postawą jest próba zrozumienia i akceptacja wad i zalet drugiej strony (partnera/partnerów), jeżeli to możliwe.

Z obserwacji autora wynika, że we wszystkich organizacjach - zarówno biznesowych, naukowych, jak i w administracji - można wskazać określone podobieństwa, takie jak: wielkość podmiotów, zdolność do sprawnego zarządzania zmianą, zwinność organizacji, kulturę organizacji. Pierwszy z wymienionych czynników ma znaczenie dla każdego rodzaju organizacji. Te spośród podmiotów, które na rynku mogą być definiowane jako duże, w wielu aspektach mają przewagę nad pozostałymi, np.: znaczący kapitał ludzki, infrastrukturę, pozycję rynkową, możliwości inwestycyjne czy logistyczne. Podmioty te potrzebują jednak określonej kultury organizacji i zdolności do efektywnego zarządzania zmianą. Wszystko po to, aby zachować zwinność - zdolność do dostosowywania się do bieżących potrzeb wewnętrznych i zewnętrznych, na tle średnich i małych konkurentów ${ }^{20}$. Owa zwinność jest najczęściej domeną małych przedsiębiorstw. Proces decyzyjny przebiega tam na ogół szybko, a zarządzający są blisko swoich klientów i produktów. Ta zdolność do reagowania na zmiany jest obecnie jeszcze bardziej pożądana w każdej organizacji ${ }^{21}$. Rozwój podmiotów - zarówno biznesowych, jak i naukowych, czy administracji w dużej mierze uzależniony jest od zachowania właściwego charakteru organizacji, proporcji pomiędzy wielkością przedsiębiorstwa, jego zdolnością do zarządzania i wdrażania zmian a zwinnością i kulturą organizacji. Podmioty średniej wielkości posiadają stosunkowo duży potencjał, a jeszcze nie straciły swojej zwinności. Małe są najczęściej bardzo zwinne, ale brakuje im potencjału, jakim dysponują te większe podmioty. Stąd wniosek, iż współpraca ze średnimi podmiotami wydaje się najbar-

20 O konkurowaniu można mówić nie tylko pomiędzy podmiotami biznesowymi, ale i instytutami badawczymi (np. w zakresie oferowanych usług, zakresu działalności, w tym działalności naukowej). W przypadku pomiotów administracji konkurowanie w praktyce jest definiowane i rozumiane nieco inaczej niż w przypadku podmiotów biznesowych.

21 Autorzy tego artykułu zwracają uwagę na aspekt struktury w firmie, kultury organizacji i niekiedy negatywnego wpływu zbytniej elastyczności w firmie. 
dziej efektywna. Niedoskonałością większości dużych podmiotów biznesowych jest długi i sformalizowany proces decyzyjny. Także ze względu na utrudniony kontakt osobisty z decydentem podmioty biznesowe potrzebują nierzadko porównywalnie dużo czasu na podejmowanie decyzji, co - często z tego powodu krytykowane - podmioty administracyjne czy jednostki naukowe. Uzasadniony jest zatem wniosek, iż zwinność tych podmiotów jest porównywalna ${ }^{22}$. Dlatego podmioty współpracujące na rzecz innowacji powinny dążyć do spersonalizowania swojej oferty, aby pełniej uwzględniać potrzeby swoich klientów/partnerów. Uzasadniona wydaje się być strategia kierowania oferty tylko dla pewnej wąskiej grupy klientów/partnerów z uwagi na właśnie zindywidualizowane potrzeby i oczekiwania - innej odpowiednio dla małych, średnich i dużych podmiotów ${ }^{23}$.

\section{Komunikacja}

W dotychczasowej współpracy z innymi podmiotami autor wielokrotnie przekonał się o wielkim znaczeniu komunikacji i negocjacji. W latach 2011-2012 uczestniczył w ciekawym projekcie jednej z warszawskich uczelni poświęconemu zarządzaniu innowacjami. Podczas zajęć odbywających się w ramach wspomnianego projektu przedstawiciel środowiska przedsiębiorców omawiał temat barier w komunikacji na przykładzie współpracy środowiska naukowego i biznesowego. Najważniejsze i nadal aktualne spośród sformułowanych wówczas tez to: (1) dostępność i możliwość szybkiego kontaktu, (2) rozmawiamy, ale nie zawsze się rozumiemy, (3) wymagamy i oczekujemy od partnera, (4) nie zawsze potrafimy otwarcie mówić o obawach, ograniczeniach we współpracy z naszej strony, (5) brak „konkretów” i decyzji w uzgodnieniach. W dyskusji z prelegentem uczestnicy spotkania zgodzili się co do trafności wskazanych niedoskonałości w obszarze współpracy, jednak przedstawiciel biznesu był przekonany, iż problemy te funkcjonują jedynie po stronie jednostek naukowych. Przytoczone przez autora przykłady przekonały go, iż do problemu należałoby podejść nieco bardziej krytycznie - również w stosunku do partnerów biznesowych. Nasze drogi zawodowe skrzyżowały się parę miesięcy później, w ramach współpracy klient - podmiot biznesowy, usługodawca - CNBOP-PIB. Była to okazja do pewnej weryfikacji w zakresie twardo formułowanych opinii dotyczących kooperacji z jednostkami naukowymi. konsorcjum w okresie sześciu tygodni było niemożliwe. W pierwszym z przykładów podpisanie umowy wstrzymywała uczelnia wyższa, a w drugim partner biznesowy. 
Teza 1. Dostępność i możliwość szybkiego kontaktu - w praktycznej współpracy obie strony wskazały osoby do kontaktów roboczych (czyli prowadzące zlecenie i upoważnione do kontaktów i innych czynności niezbędnych w procesie). Strona naukowa dość szybko otrzymała informację zwrotną, iż jej pracownik nie odbiera od razu telefonu, a na e-maile odpisuje tylko raz dziennie. W wyniku próby wyjaśnienia sytuacji udało się ustalić, iż faktycznie pracownik nie mógł odebrać telefonu - był na spotkaniu z innym klientem, dlatego wysłał do partnera biznesowego wiadomość SMS i oddzwonił po około godzinie. W odniesieniu do korespondencji e-mailowej faktem jest, iż pracownik - z uwagi na charakter wykonywanej pracy z wykorzystaniem specjalistycznych stanowisk badawczych - na korespondencję e-mailową może odpowiadać rano i po południu, po zakończeniu badań. Partner biznesowy nie uznał do końca tych wyjaśnień. Obie strony umówiły się więc, iż w sprawach wyjątkowo pilnych będzie dzwonił bezpośrednio do przełożonych. Zaproponowane rozwiązanie bardziej usatysfakcjonowało klienta, niemniej przedstawiciel biznesu podtrzymywał swoją opinię o potrzebie zatrudnienia dodatkowych pracowników w instytucie oraz poprawy komunikacji z klientami. W dalszej dyskusji strony doszły do pewnego kompromisu - przecież klient ma „opiekuna”, a sam zlecony proces z uwagi na jego zakres, charakter i złożoność nie trwa godzinę, tylko kilka tygodni. Prawdziwy przełom w kontaktach nastąpił jednak 2-3 tygodnie później. W realizowanym zleceniu pojawił się problem negatywnego wyniku jednego z badań. Klient, zgodnie z procedurą laboratorium, został o fakcie poinformowany e-mailem, upoważniony przedstawiciel klienta otrzymał wszystkie szczegóły także drogą telefoniczną. Ponieważ w takich sytuacjach konieczna jest decyzja klienta co do kontynuacji badania, stronę naukową niepokoiło kilkudniowe milczenie. Okazało się, że wszyscy pracownicy firmy byli zaangażowani w udział w targach, a dodatkowo pracownik prowadzący sprawę i znający wszystkie szczegóły się rozchorował. Kiedy obie strony spotkały się po zakończeniu realizacji zlecenia, klient wykazał się wysokim poziomem samokrytycyzmu i tezę dotyczącą dostępności i możliwości szybkiego kontaktu nieco zweryfikował, uwzględniając oczywiste ograniczenia własne. Ten i wiele innych przykładów ze współpracy z klientami przekonały autora do twierdzenia, iż dużo łatwiej nam oceniać niedoskonałości swoich partnerów, dużo trudniej dostrzec je i skorygować po własnej stronie. Czasami też myślimy stereotypami; ktoś działa nieefektywnie - nie widzimy i nie chcemy widzieć ograniczeń naszych partnerów, chętniej usprawiedliwiamy siebie własnymi ograniczeniami, które znamy doskonale, bo są wspólne dla całej organizacji. 
Teza 2. Rozmawiamy, ale nie zawsze się rozumiemy - w ramach opisanego powyżej przykładu współpracy, również ta druga teza przedsiębiorcy uległa pewnej ewolucji. Przy prowadzeniu precyzyjnych uzgodnień udało się wyeliminować wszelkie rozbieżności. Pomocne okazało się doświadczenie instytutu w realizacji usług dla wszystkich podmiotów (nie rozróżniając ich na małe, średnie i duże). Nie zawsze jednak tak bywa, dlatego od lat w reprezentowanym przez autora instytucie szczególny nacisk kładzie się na kompleksowe zapisy ofert, zawieranych informacji i dedykowanych informatorów, a także dodatkowo standardów i innych opracowań opisujących konkretne zagadnienia. Upewnianie się, iż obie strony rozumieją w sposób jednakowy warunki współpracy jest - w przekonaniu autora - najskuteczniejszą metodą minimalizującą ryzyko rozbieżności.

Teza 3. Wymagamy i oczekujemy od partnera - podobnie jak w przypadku komunikacji, znacznie łatwiej wymagać od partnera niż od siebie. Autor publikacji miał styczność z klientami, którzy - często emocjonalnie - artykułowali swoje ograniczenia, potrzeby i oczekiwania (dotyczące np. czasu wykonania określonych prac), nie chcąc jednak uwzględniać ograniczeń drugiej strony. Klienci ci zapewne mieli na myśli stwierdzenie Ferdinanda Fourniesa: „Sekretem utrzymania lojalności klienta jest troska o jego interesy, rolą sprzedawcy jest pomóc klientowi dokonać jak najlepszego zakupu”. Przypomnieć jednak trzeba, że produkt sprzedaży był już ustalony, a dyskusja dotyczyła jedynie terminu dostawy. Przykład, który może uzmysławiać, dlaczego tak łatwo nam usprawiedliwiać swoje ograniczenia, a niechętnie lub w ogóle nie chcemy poznawać - tym bardziej uwzględniać - ograniczeń partnerów, przedstawiono poniżej. Jeden z klientów instytutu, który dość często formułuje uwagi i demonstruje niezadowolenie, kiedy jego zlecenie nie może być zrealizowane „natychmiast”, zobowiązał się w umowie do wykonania elementu infrastruktury badawczej. Ponieważ było pilne, termin realizacji ustalono na 8 tygodni, przy czym klient zadeklarował ustnie, iż wykonanie usługi nie zajmie dłużej niż 4 tygodnie. Instytut, zlecając tę pracę, miał jednak na uwadze, iż 4 tygodnie po planowanej według umowy dostawy elementu infrastruktury chce uruchomić nowe stanowisko badawcze. Realizacja ta opóźniła się o ponad 6 tygodni, stanowisko zostało uruchomione znacznie po terminie, a instytut zrezygnował ze zlecania dalszych prac temu klientowi. Po zakończeniu tej nieudanej współpracy strony odbyły niełatwą rozmowę. Zleceniobiorca nie poczuwał się do winy w sprawie, miał bowiem w tym okresie wiele nieplanowanych zleceń, a na drodze realizacji opisywanego projektu pojawiły się nieprzewidziane trudności. Wszystkie te czynniki miały wpływ na wydłużenie prac. Po tej rozmowie klient nadal nie widział własnych ograniczeń, za to za każdym razem formułował uwagi 
co do problemów leżących po stronie instytutu jako usługodawcy. Słuchanie swoich klientów jest bardzo ważne. Korzyści dla organizacji w praktyce wynikają z umiejętnego uwzględniania potrzeb klientów i precyzyjnego komunikowania własnych ograniczeń.

Teza 4. Nie zawsze potrafimy otwarcie mówić o obawach, ograniczeniach we współpracy z naszej strony - często trudno być obiektywnym wobec siebie czy swojej firmy. Jest to jednak możliwe, trzeba wyjść z własnej „roli”. Pomocne jest umiejętnie korzystanie z opinii swoich klientów ${ }^{24}$. Podsumowując, bariery dla współpracy mogą pojawić się po stronie każdego partnera. Kluczowa jest umiejętność ich ujawniania i akceptowania, czyli znajdowania kompromisów poprzez dialog i precyzyjne uzgodnienia.

Teza 5. Brak konkretów i decyzji w uzgodnieniach - aby uzgodnienia były konkretne i poparte decyzjami, konieczne jest nie tylko właściwe przygotowanie, ale czasami również dostosowanie się do partnera. Gdy brakuje tej umiejętności, warto oprzeć się na sprawdzonych wzorcach. Propozycji można znaleźć wiele, wśród nich na uwagę zasługują te praktyczne i nieskomplikowane ${ }^{25}$.

\section{Emocje}

W komunikacji ważne jest panowanie nad emocjami, a jeszcze cenniejsza umiejętność zarządzania nimi. Zdolność rozpoznawania i kontrolowania emocji własnych i innych ludzi przynosi nam liczne korzyści. Konieczne jest jednak rozwinięcie inteligencji emocjonalnej, aby poprawić sprawności menadżerskie. Korzystamy z nich intuicyjnie, można je również wyćwiczyć. W procesie tym ważne jest, aby próbować zrozumieć, jakie emocje towarzyszą drugiej osobie podczas rozmowy, pracy, negocjacji ${ }^{26}$.

\section{Negocjacje}

Negocjacje najczęściej kojarzą się z kupowaniem, ustalaniem ceny i warunków. D. Shapiro w publikacji pt. Negocjuj nienegocjowane ${ }^{27}$ przedstawia szczegółowo i kompleksowo zagadnienie negocjacji na podstawie prowadzonych badań

24 E. Trivesan E. , W. Gorzeń, R. Zinoecker, Jak zrozumieć Klienta i na tym zarobić?, Wydawnictwo ICan Institute, Warszawa 2013.

25 „- Zaplanuj każdą rozmowę tak, by każdy wiedział, jakie są jej cele i jak w niej uczestniczyć. - Pilnuj przebiegu rozmowy tak, by nie schodzić na tematy poboczne i by nikt nie tracił uwagi. - Zakończ rozmowę tak, by wszyscy wiedzieli, co mają robić dalej i mieli świadomość wartości tej rozmowy”. Żródło: P. Axtell, Jak najlepiej zakończyć spotkanie?, Harvard Business Review Polska, https://www.hbrp.pl/ [dostęp: 20.02.2020]. 
i doświadczenia zawodowego. Publikacja ta uzmysławia, iż w praktyce negocjujemy codziennie wiele różnorodnych kwestii, nie zawsze będąc tego świadomymi. Robimy to intuicyjnie lub zdobywamy i doskonalimy swoje umiejętności, jesteśmy teoretykami albo praktykami w tym zakresie. Świadomość i wiedza w obszarze negocjacji są niezwykle użyteczne i pomocne. W podsumowaniu wspomniany wyżej autor o swojej publikacji mówi jako o podróży odbytej do świata rozwiązywania konfliktów. Podróż ta ma pozwolić odkryć narzędzia pomagające zneutralizować antagonistyczne siły konfliktu i stymulować dynamikę procesu integracyjnego. Autor zachęca przede wszystkim, aby wypróbować w praktyce przedstawioną w publikacji wiedzę, narzędzia, rozumienie i podejście do negocjacji - sprawdzać, co zadziała w konkretnych sytuacjach konfliktowych. Ponadto D. Shapiro stwierdza, iż dochodzenie do porozumienia nie ma nic wspólnego z socjotechniką, bowiem o ostatecznym sukcesie decyduje przede wszystkim duch pojednania.

Wśród licznych, praktycznych, opartych na badaniach naukowych, wdrożeniach i doświadczeniach autora propozycji użyteczne są przede wszystkim wskazówki, takie jak: (1) „Pojednanie to wybór”, (2) „Małe zmiany mogą spowodować wielkie różnice”, (3) „Nie czekaj”. W rozwinięciu ich autor stwierdza między innymi, iż nikt nas nie może zmusić do pojednania - początkiem jego jest przekonanie, iż jest ono możliwe. Kluczowe w tym wyborze jest zarządzanie swoimi uczuciami i podejmowane decyzje, a także wiara w możliwość zmian. Ponadto konieczna jest wyobraźnia do poszukiwania pozytywnych możliwości².

Pisząc o zmianach, autor zwraca uwagę, iż każdy pozytywnie rozwiązany konflikt oddziałuje na świat. Wyjaśnia, iż na przykład rozwiązanie konfliktu w życiu prywatnym stwarza możliwości do poprawy relacji w pracy. Ponadto w punkcie tym znajdziemy zachętę do działań i nieczekania, czyli poświęcania konfliktom należytej uwagi. Najtrudniejszej walki na rzecz pojednania nie toczymy z innymi ludźmi, lecz z samym sobą, kluczowy bowiem jest opór wewnętrzny każdego z nas. Można go pokonać jedynie samodzielnie, przez świadome wybory ${ }^{29}$.

Negocjacje tak rozumiane w praktyce okazują się niezwykle użyteczne - jeśli nie kluczowe - dla osiągania celów, komunikacji, prowadzenia ustaleń, współpracy, wdrożeń i innowacji. Najistotniejsze wydaje się w nich słuchanie oraz rozumienie możliwości i ograniczeń stron.

28 Autor cytując A. Einsteina, przywołuje stwierdzenie: „Wyobraźnia jest ważniejsza od wiedzy”.

29 D. Shapiro, dz. cyt., s. 218-219. 


\section{Wdrażanie nowych technologii i rozwiązań | Współpraca}

\section{Ludzie}

Organizacja to ludzie. Kapitał ludzki organizacji jest kluczowy dla jej funkcjonowania i rozwoju. Poszczególne grupy i ludzi wyróżniają ich umiejętności, kompetencje i postawa. Ludzi sukcesu cechuje niesamowita wytrwałość. Nawet gdy nie są najlepsi w swojej dziedzinie, nadal starają się doskonalić i są gotowi na poświęcenia, gdy ich praca tego wymaga. Co istotne, nawet gdy mogą wybrać alternatywną, łatwiejszą drogę, ich zaangażowanie nie słabnie. Tę wyjątkową kombinację mocnych stron najczęściej określa się determinacją lub uporem ${ }^{30}$. Jednak pozyskanie i utrzymanie pracowników o przywołanych cechach zależy od kultury organizacji. Coraz częściej - nawet dla największych i najbardziej prestiżowych firm na świecie - poważnym wyzwaniem jest nie tylko pozyskanie talentów, ale również ich utrzymanie. Zbudowanie odpowiedniej kultury organizacji daje większe szanse na zmniejszenie rotacji nawet najbardziej poszukiwanych specjalistów ${ }^{31}$. Przy tym wielu specjalistów i badaczy podkreśla rolę wartości w organizacji. Mają one bezpośrednie znaczenie dla kształtowania i ujawniania postaw pracowników. W. Buffet stwierdza, iż przy rekrutacji nowego pracownika liczą się tylko trzy rzeczy: inteligencja, inicjatywa i uczciwość. Jeśli brakuje tej ostatniej, dwie pierwsze mogą okazać się zabójcze. Jeśli zatrudnisz kogoś nieuczciwego, to lepiej dla Ciebie, żeby okazał się głupi i leniwy. To bardzo surowe i bezkompromisowe stwierdzenie. Uzmysławia jednak, iż podstawową wartością dla organizacji jest właśnie uczciwość. Bez niej zarówno inicjatywa, jak i inteligencja mogą szkodzić organizacji.

\section{Liderzy}

Dla osiągania celów konieczni są liderzy zadań, projektów, wdrożeń czy innowacji. „Jeżeli chcemy wygrywać w coraz mniej przewidywalnym świecie, musimy wciąż pracować nad podtrzymywaniem naszej przewagi konkurencyjnej, która stała się dobrem wyjątkowo nietrwałym. Zmiany technologiczne i społeczne, zmiany w zachowaniach konsumenckich czy przełomowe innowacje mogą w każdej chwili podkopać jej fundament i położyć na łopatki dotychczasowych liderów rynku”32. W organizacji praca liderów bezpośrednio przekłada się na jej kondycję. Dowodzi tego między innymi R. Nader, amerykański polityk, autor książki Unsafe at Any Speed (Niebezpieczne przy każdej szybkości). Stwierdza on w tej publikacji, iż najważniejszą rolą lidera jest inspirowanie innych do bycia liderami w miejscach, w których

\footnotetext{
30 T. H. Lee, A. L. Duckworth, Zdetereminowana oragnizacja, „Harvard Business Review Polska” 2019, 194(4), s. $123-131$. 
działają, a nie produkowanie wyznawców i biernych naśladowców. Tematyka ta jest obecna w aktualnej ofercie na rok 2020 Ican Institute w ramach cyklu konferencji tematycznych pt. Elite Leadership Program 202033. Możemy tam przeczytać o czterech kluczowych rolach lidera. Umiejętność ich połączenia decyduje o efektywności działania. Te kluczowe dla skuteczności lidera zostały nazwane rolami:

- skutecznego stratega (kreującego przyszłość firmy),

- coacha (umiejętnie motywującego zespół do działania),

- wizjonera (wyprzedzającego rynkowe trendy),

- przywódcy (prowadzącego organizację ku następnym sukcesom).

Umiejętne łączenie i wykorzystywanie tych ról umożliwia liderom poszukiwanie nowych rozwiązań pozwalających wyprzedzić konkurencję. Lider bowiem, aby wygrywać w dynamicznie zmieniającej się rzeczywistości biznesu, musi stale zwiększać efektywność: swoją, swojego zespołu i całej firmy ${ }^{34}$. Łączenie tych umiejętności to wyzwanie i potrzeba dla wdrożeń i innowacji, jak i dla codziennego doskonalenia organizacji i procesów. Działania te - niezależnie od wieku, branży, doświadczenia - zawsze mają pewne znamiona niepewności i eksperymentu. W poszukiwaniu przez liderów swojej recepty na sukces warto mieć na uwadze słowa poety i pisarza, mówcy R. W. Emersona: „Nie bądź zbyt wrażliwy i krytyczny w stosunku do swoich działań. Całe życie jest eksperymentem”.

\section{Przywództwo}

Według P. Druckera zarządzanie to robienie rzeczy we właściwy sposób, a przywództwo - robienie tych właściwych rzeczy. P. Motyl35 rozwijając tę tezę stwierdza, że menadżerowie gwarantują, iż organizacja będzie działać w sposób powtarzalny. Przywódcy z kolei dokonują strategicznych wyborów, nakreślają wizję, inspirują innych, by podążali w wyznaczonym kierunku. Menadżer korzysta z władzy nadanej formalnie, przynależnej stanowisku, a lider wpływa na innych, bo inni tego chcą.

Wdrażanie produktów, rozwiązań i zmian wymaga liderów i menadżerów. P. Motyl w przywołanej publikacji podkreśla, iż dla zapewnienia rozwoju wewnątrz organizacji należy zachować właściwe proporcje pomiędzy inspirującymi wizjonerami i skutecznymi wykonawcami. Autor ten zwraca również uwagę, iż lider ma do dyspozycji co najmniej pięć ról w podejmowaniu decyzji36:

Elite Leadership Program 2020, Strona internetowa Ican Institute, https://elp.hbrp.pl/?utm_medium=email\&utm source=getresponse\&utm_campaign=ELP [dostęp: 25.02 .2020 ]. 
1) wizjoner i strateg,

2) agent zmiany,

3) architekt kultury organizacji,

4) adwokat obietnicy marki,

5) twórca infrastruktury decyzyjnej.

Przywództwo poza wymiarem personalnym jest obszarem badań i rozważań w kontekście przywództwa na rynku. Badania w tym zakresie dowodzą, że jest ono coraz bardziej tymczasowe. Aktualnie coraz częściej wyzwaniem dla firm nie jest dotarcie na przysłowiowy „szczyt”, ale utrzymanie uzyskanej pozycji rynkowej ${ }^{37}$.

M. Moldoveanu i D. Narayandas w artykule pt. Przyszłość branży kształcenia liderów twierdzą, iż nigdy dotąd potrzeba rozwijania cech przywódczych nie była tak pilna jak dzisiaj. Firmy w zmiennym, złożonym i niejednoznacznym otoczeniu rynkowym potrzebują umiejętności przywódczych i zdolności organizacyjnych innych niż te, które pomagały im odnosić sukcesy w przeszłości. Rośnie również świadomość, iż doskonalenie cech przywódczych nie powinno być ograniczone do garstki ludzi (czyli zarządu i osób blisko z nim współpracujących) ${ }^{38}$.

\section{Technologia}

M. Petrykowski, dyrektor zarządzający S\&P Global Ratings twierdzi, że przy komercjalizacji projektów kluczowy jest sposób zarządzania. Ponadto w jego opinii na rynku polskim właściciele firm często mają problem z oddawaniem odpowiedzialności, delegowaniem zadań oraz wykorzystaniem profesjonalnego zewnętrznego talentu. To wynika z uwarunkowań naszego - wciąż jeszcze relatywnie młodego - rynku biznesowego. Wspomniany autor dostrzega ograniczenie takiego biznesu w podejściu właścicieli do ich przedsiębiorstw, żyjących w przeświadczeniu, że tylko oni wiedzą, co robić, by firma dalej się rozwijała. Podkreśla, iż nierzadko brak jest zrozumienia, że umiejętności, które doprowadziły firmę do dzisiejszego sukcesu i skali często nie wystarczą do jego kontynuacji. To niestety ogranicza przyszły potencjał wielu pierwszo pokoleniowych biznesów - wyjaśnia.

37 „Badanie przeprowadzone w ciągu ostatnich czterech dekad wśród 22000 firm pokazuje, że w dobie zmieniającego się otoczenia biznesowego pozostanie liderem jest dużo trudniejsze niż osiągnięcie przewagi. Spośród firm, które zdobywały pozycję lidera w ostatnich 40 latach, zaledwie $17 \%$ z nich było w stanie utrzymać swoją przewagę przez następne pięć lat. W czym tkwił ich sekret? Firmy te - w tym organizacje takie jak Apple i Alphabet - nieustannie znajdują nowe źródła przewagi konkurencyjnej, zmieniając swoje firmy i dostosowując się do zmieniających się warunków rynkowych. Ich przykład oferuje lekcje dla zespołów przywódczych próbujących walczyć z nieugiętym naciskiem konkurencji”. Źródło: Strona MIT Sloan Management Review (MIT SMR), sloanreview.mit.edu [dostęp: 25.02.2020].

38 M. Moldoveanu, D. Narayandas, Przyszłość branży ksztatcenia liderów, „Harvard Business Review Polska” 2019, 194(4), s. 44-53. 
W swoich rozważaniach M. Petrykowski zadaje także pytanie: czy młodszy rynek startupowy jest inny? W odpowiedzi stwierdza, iż tu również kluczowy jest różnorodny sposób zarządzania, bo w tworzeniu start-upu ważny jest pomysł, jego potwierdzenie z potencjalnymi klientami oraz egzekwowanie. Do firmy wybiera się ludzi ze względu na ich kompetencje, bo to na zespole spoczywa odpowiedzialność za realizację, budowę produktu, działanie i zdobywanie rynku. Jeśli założyciel firmy wymyśli innowacyjne rozwiązanie technologiczne, to jak najszybciej musi pozyskać pracownika, który ma doświadczenie w komercjalizacji projektów oraz umie sprzedawać.

Przytoczone powyżej przemyślenia pozwalają sformułować tezę, iż technologia to za mało. Do jej wdrożenia i komercyjnego sukcesu potrzebne są liczne działania, a także uwzględnienie co najmniej kilku czynników biznesowych, organizacyjnych i ludzkich. Kluczowe jest dobre zaplanowanie procesu i przekazywanie pracownikom niezbędnej wiedzy. Dodatkowym wyzwaniem jest to, że w ramach edukacji szkolnej najczęściej nie uczymy się pracy zespołowej. W szkole na ogół jesteśmy lepiej oceniani, gdy wyróżniamy się na tle grupy. W pracy zawodowej chodzi jednak o to, aby wspólnie wykonać zadania ${ }^{39}$. Dziś konkurujemy jakością, innowacjami, konstelacjami z dostawcami, outsourcingiem, sojuszami biznesowymi. Dlatego bardzo ważna jest współpraca start-upów z korporacjami, które poszukują innowacyjnych rozwiązań. Duże korporacje można porównać do statku, który oferuje szerokie możliwości, bezpieczeństwo, ale jest jednak powolny - szczególnie, gdy konieczna jest szybka zmiana kursu. Mała łódka nie jest aż tak dobrze wyposażona, ale za to zwrotna. Gdy liczy się spryt i szybkość, może ona wygrać z dużym statkiem. Według E. Pasewicz mądrość i dużych, i małych polega na szukaniu synergii i umiejętności korzystania z atutów każdej ze stron. Między innymi w raporcie Huge Thing ${ }^{40}$ wskazywane są czynniki, które wpływają na sukces współpracy na linii start-up - korporacja. Przede wszystkim są to dobrze zdefiniowane cele współpracy (71,4\% firm szuka rozwiązań optymalizacji procesów wewnętrznych, a 28,6\% - rozwiązań komplementarnych do prowadzonego biznesu). Kluczowe jest zdefiniowanie warunków, jakie musi spełnić start-up, aby kooperacja była możliwa - wiele firm już na początku rezygnuje z rozwiązań, których wdrożenie wymaga zbyt skomplikowanej integracji z posiadanymi systemami. nie jednostek. Zespół, choć trudniej zarządzany, na ogół nie myli się aż tak bardzo, jak jest to możliwe w przypadku poszczególnych jego członków. 
Według M. Synoradzkiej kolejny ważny element to zespół odpowiedzialny za wyszukanie i testowanie innowacji: czy są w nim kompetentne osoby, jak wysoko w strukturach firmy jest umocowany, czy ma wsparcie ze strony zarządu. Natomiast ostatni istotny czynnik stanowi kultura innowacji w firmach, która bywa zbyt słabo rozwinięta albo ograniczona do kilku osób. Ludzie nie rozumieją, po co są innowacje, co one zmienią, nie czują się zaangażowani w te zmiany i ich nie wspierają. Budowanie kultury innowacji to jedno z największych wyzwań korporacji w Polsce. Jeśli duże organizacje będą uczyć pracowników pracy z innowacjami, będą zachęcać ich do opracowywania nowych rozwiązań, angażowania się w zmiany, to wpłynie to na wszystkie aspekty kluczowe dla zmian w organizacjach. Co ważne, taka zmiana powinna zacząć się na najwyższym poziomie firmy, w zarządzie ${ }^{41}$.

W tym kontekście powstaje pytanie o sposób wykorzystywania nowych technologii przez firmy. Na łamach „MIT Sloan Management Review” zespół pod kierownictwem Paula R. Daugherty’ego, CIO i CTO ${ }^{42} \mathrm{w}$ firmie Accenture prezentuje wyniki badań i wnioski. Badaniu poddano systemy operacyjne firm, analizując decyzje dotyczące wdrażania nowych technologii (w 8300 przedsiębiorstwach z 20 branż i 20 państw). Konkluzje z tych badań zawierają się między innymi w stwierdzeniach: Niezależnie od branży każda firma jest dziś firmą technologiczną. Prezesi firmy - czy tego chcą, czy nie - powinni być również specjalistami w dziedzinie nowych technologii. To właśnie technologii dotyczą najważniejsze decyzje rozwojowe podejmowane obecnie w firmach. Inwestowanie w technologie cyfrowe daje największe szanse na wyraźny wzrost dochodów. Transformacja cyfrowa, nie cyfryzacja - autorzy badania zwracają uwagę na tę różnicę.

\section{Innowacje}

Einstein powiedział: „Ucz się z tego, co wydarzyło się wczoraj, żyj dniem dzisiejszym, ale nadzieję pokładaj w jutrze. Najważniejsze, byś zawsze pozostał otwarty na nowe pytania”. To przesłanie sprzed lat pozostaje aktualne i ważne, również w kontekście dzisiejszego otoczenia oraz rozumienia zmian i innowacji. Podobnie jak cytowany A. Einstein, wielu ludzi imponujących osiągnięć - wynalazców i wizjonerów - w swoich opiniach dotyczących innowacji podkreśla potrzebę innego podejścia, myślenia i działania niestandardowego.

\footnotetext{
41 J. Rubin, Jak wprowadzać przełomowe innowacje?, Portal internetowy Ican Institute, https://www.ican.pl [dostęp: 20.02.2020].

42 Chief Information Officer (CIO), Chief Technology Officer (CTO).
} 


\section{Wdrażanie nowych technologii i rozwiązań | Współpraca}

A. Ekert, współwynalazca kryptografii kwantowej, w wywiadzie dla MITSMR.pl powiedział, iż kilka razy w życiu spotkał się z sytuacją, w której rezygnacja z podejścia czysto praktycznego i skupiania się na tym, co w danym momencie wydawało się najbardziej korzystne czy racjonalne, przynosiło bardzo dobre rezultaty w przyszłości. Wspominając dalej swoje studia na Oxfordzie i zajmowanie się już wówczas kryptografią kwantową, zwraca uwagę, iż wówczas był to temat, który odradzano studentom. Był on traktowany jak filozofia fizyki, a wszystko, co kojarzyło się wtedy z filozofią, odbierane było jako niepoważne. Obecnie okazuje się, że kryptografia kwantowa jest bardzo potrzebna.

Pamiętać dlatego należy, iż początki prac w ramach projektów, tworzenia prototypów, poszukiwanie nowych rozwiązań wcale nie muszą być innowacyjne (najczęściej nie są). O zarządzaniu talentami, konkretnych przykładach działań i dobrych praktyk, w tym tworzeniu innowacji między innymi opowiada P. McCord w swojej książce Powerful43: „Zatrudnialiśmy bardzo utalentowanych ludzi, o zupełnie nowych kompetencjach, a skład naszych zespołów płynnie się zmieniał. W każdej chwili musieliśmy być również gotowi, aby porzucić to, co planowaliśmy, przyznać się do błędów i przyjąć nowy cel, w tym nieustannie wymyślanie na nowo. Nie mieliśmy jednego momentu olśnienia, nowy sposób działania tworzyliśmy przez stopniową adaptację: testowanie nowych rzeczy, popełnianie błędów, rozpoczynanie od początku i obserwowanie rezultatów”. Na kolejny ważny aspekt dla innowacji zwraca się uwagę na studiach Launching Breakthrough Technologies na Harvard University, podkreślając jak ważne jest, aby z produktem wyjść szybko na rynek. Należy zapytać przynajmniej stu potencjalnych klientów, co sądzą o naszym produkcie. Czy rynek w ogóle go potrzebuje? W jakim czasie? Jakie mogą być inne scenariusze jego użycia? Ludzie albo mogą napędzać komercjalizację produktu, albo ją hamować. Mogą być elastyczni albo zamknięci na podpowiedzi innowatorów. Start-up często tworzy bardzo mała grupa ludzi. Każdy ma wpływ na to, jak kształtuje się firma. Każda decyzja ma znaczenie. Sam produkt można technicznie dopracować, ludzi natomiast trudniej przetransformować. Czynnik ludzki to najsłabsze lub najsilniejsze ogniwo. Jak można wnioskować, nie ma jednej drogi i recepty na sukces. Zarządzanie umiejętnościami i talentami, sztuka wyborów, odpowiedzialność i błędy są obecne w drodze po sukcesy, ale i w porażkach.

P. McCord, Powerful, Jak zbudować kulturę wolności i odpowiedzialności, e-book, Wydawnictwo BeeBooks, 2019. 


\section{Wdrażanie nowych technologii i rozwiązań | Współpraca}

M. Synoradzka, CEO Huge Thing i partner zarządzająca SpeedUp Group omawia badania jakościowe, które przeprowadzili w dużych organizacjach na potrzeby raportu Huge Thing Czy korporacje w Polsce sa gotowe na wspótpracę ze start-upami z roku 2019. Potwierdzono nimi, że jednym z kluczowych czynników warunkujących sukces pracy z innowacją w firmie jest kultura innowacji. „Oznacza to, że jeśli w zespołach odpowiedzialnych za dostarczanie innowacji są ludzie, którzy rozumieją potrzebę zmian w firmie, to jednym z większych wyzwań, jakie mają do pokonania, jest przekonanie całej rzeszy oponentów, że innowacje mają znaczenie i są niezbędne do rozwoju organizacji. W dużych polskich organizacjach kultura innowacji albo jest na etapie rozwoju albo nie istnieje. Nieliczne są przykłady firm, w których pracownicy czują, że innowacje są ważne, a oni mogą być nośnikami zmian”.

Dlatego wynalazki to jeszcze nie innowacje. Wynalazki często nie wychodzą poza laboratorium. Innowacja to sposób użycia wynalazku, który zmienia myślenie lub przyzwyczajenia ludzi. Wielokrotnie to sztuka edukacji rynku z jednoczesnym procesem sprzedażowym, żonglowanie wieloma procesami na raz z wiarą, że na koniec wszystkie one spotkają się w jednym punkcie i zostaną okrzyknięte sukcesem. E. Pasewicz pracująca w 2012 roku w firmie IMPAQ postanowiła szukać innowacji w branży finansowej, by poprzez rozwój systemu osiągnąć rozwiązanie do zapobiegania nadużyciom w obszarze fraudów kredytowych i pracowniczych. Uzmysłowiła sobie wówczas, iż aby naprawdę stworzyć innowację, musi najpierw zrozumieć, co jest dostępne na rynku, jak należy się wyróżnić, czego brakuje, za co klienci będą chcieli zapłacić. Zapytała więc potencjalnych klientów, czy w ogóle potrzebują takiego rozwiązania i czy jest już jakiś produkt, który spełni ich oczekiwania. Okazało się, że aktualne produkty rynku nie są adekwatne do dynamicznych zmian, jakie zachodzą w sektorze bankowym. „Zapoczątkowałam współpracę z trzema dużymi bankami w Polsce. Partnerstwo, dialog i otwartość doprowadziły do tego, że stworzyliśmy takie rozwiązanie, które było innowacyjne i wielokrotnie nagradzane przez Związek Banków Polskich czy „Gazetę Bankową”. Z punktu widzenia komercjalizacji osiągnęłam to, co jest krytyczne, a jednocześnie najtrudniejsze - posiadanie komercyjnych klientów, którzy zapłacą za rozwiązanie, jak również staną się rzeczywistą referencją, że dany produkt ma realną potrzebę biznesową, a nie tylko istnieje w głowach współtwórców" - podkreśla E. Pasewicz ${ }^{44}$.

44 J. Rubin, Jak wprowadzać przełomowe innowacje?, dz. cyt. 
P. Motyl natomiast w publikacji LABIRYT sztuka podejmowania decyzji ${ }^{45}$ za najskuteczniejsze uważa te organizacyjne, w których pojawiała się zawsze kombinacja czterech elementów bezpośrednio rzutujących na jakość podejmowanych decyzji i przekładających się na zwinność biznesową: przejrzysta infrastruktura decyzyjna, ciągłe doskonalenie, kultura organizacyjna promująca bezpieczeństwo psychologiczne (otwartość komunikacji, zachęcanie do wyrażania odmiennych opinii), rozproszone przywództwo. Według tego autora połączenie powyższych elementów pozwala na podejmowanie szybkich i zbliżonych do optymalnych decyzji, ale daje też szanse na lepsze zrozumienie ich konsekwencji w innych obszarach działalności organizacji.

\subsection{Wnioski}

Na podstawie prowadzonych prac, badań i wieloletnich doświadczeń zawodowych, analizy literatury podjęto próbę zwięzłego przybliżenia wybranych, najważniejszych zagadnień dotyczących uwarunkowań i możliwości wprowadzania nowych technologii i rozwiązań w zakresie ochrony przeciwpożarowej. Rozważania te odniesiono przede wszystkim do wyrobów i usług w zakresie ochrony przeciwpożarowej.

Ocena zgodności wyrobów stosowanych na rzecz ochrony przeciwpożarowej, a także i ochrony środowiska, jest regulowaną prawnie podstawą (fundamentem) dla skutecznego zapewnienia bezpieczeństwa pożarowego. Rozwiązanie takie funkcjonuje w większości państw. Konieczna jest jej racjonalizacja i dostosowywanie do zamieniających się potrzeb (w warunkach polskich ma ono zastosowanie do procesów na poziomie UE i krajowych). Znacząco większe potrzeby są ujawnione w obszarze zapewnienia jakości usług na rzecz ochrony przeciwpożarowej. Aktualnie w Polsce certyfikację usług na zasadzie dobrowolności oferują dwa podmioty (jednostki certyfikujące). Z tej oferty korzysta ponad sto firm projektujących, instalujących oraz konserwujących czynne i bierne zabezpieczenia przeciwpożarowe. Nową propozycją CNBOP-PIB, mającą swoje podstawy prawne, jest certyfikacja w ramach zintegrowanego systemu kwalifikacji (ZSK) ${ }^{46}$. Nadal oferta

45 P. Motyl, LABIRYT..., s. 275.

46 Zintegrowany System Kwalifikacji (ZSK) to europejski, praktyczny standard w zakresie edukacji przez całe życie, bazujący na efektach uczenia się, który umożliwia zdobycie, potwierdzenie wymaganych kwalifikacji. Podjęcie przez CNBOP-PIB działań polegających na opisie kwalifikacji w zakresie projektowania, montażu i konserwacji zabezpieczeń (urządzeń) przeciwpożarowych w ZSK wynika wprost z realizacji zapisów art. 4 ust. 2 ustawy o ochronie przeciwpożarowej („Czynności z zakresu ochrony przeciwpożarowej mogą wykonywać osoby posiadające odpowiednie kwalifikacje”). Należy dodać, że do tego zakresu kwalifikacji nie zaliczają się formalne uprawnienia budowlane. Kwalifikacje zgłoszone przez CNBOP-PIB w ramach ZSK obejmują następujące (zdefiniowane w obowiązujących przepisach) typy technicznych zabezpieczeń (urządzeń) przeciwpożarowych:

- projektowanie zabezpieczeń przeciwpożarowych - dźwiękowe systemy ostrzegawcze (DSO);

- montaż i konserwacja zabezpieczeń przeciwpożarowych - dźwiękowe systemy ostrzegawcze (DSO); 
certyfikacji dotyczy kwalifikacji nieformalnych, ale umieszczenie ich w systemie ZSK pozwali w przyszłości na uznanie ich jako formalne. Ponadto są one wpisane w ramy kwalifikacji ${ }^{47}$, które funkcjonują w państwach UE. Dodatkowe najważniejsze informacje o ZSK w ochronie przeciwpożarowej umieszczono w załączniku 1.

Powyżej scharakteryzowano uwarunkowania istotne dla możliwości wdrażania nowych wyrobów i rozwiązań, a także dla tworzenia innowacji: podstawy formalne, ekosystem dla innowacji oraz zaufanie do nowych rozwiązań i wyrobów.

Ważnym elementem wspierającym wdrażanie innowacji jest współpraca świata nauki i biznesu. Środowisko naukowe w Polsce podkreśla, że rozwiązania systemowe takie jak nowa ustawa o innowacyjności i przygotowywane wprowadzenie ułatwienia zwanego Innovation Box, w połączeniu z rozwiązaniami systemowymi zwiększającymi doskonałość wdrożeniową, powinny skłaniać przedsiębiorców do inwestowania w badania i rozwój, a przede wszystkim do podejmowania ryzyka wdrażania nowych technologii i nowych produktów ${ }^{48}$. To ważne zwrócenie uwagi na potrzeby współpracy nauki i biznesu na rzecz innowacji. Dla efektywności tego procesu podstawą jest umiejętność komunikacji i współpracy, stworzenie warunków dla niej i konieczna otwartość na nowe rozwiązania i innowacje.

- projektowanie zabezpieczeń przeciwpożarowych - stałe urządzenia gaśnicze gazowe (SUG-G);

- montaż i konserwacja zabezpieczeń przeciwpożarowych - stałe urządzenia gaśnicze gazowe (SUG-G);

- projektowanie zabezpieczeń przeciwpożarowych - systemy sygnalizacji pożarowej (SSP) i sterowania urządzeniami przeciwpożarowymi;

- montaż i konserwacja zabezpieczeń przeciwpożarowych - systemy sygnalizacji pożarowej (SSP) i sterowania urządzeniami przeciwpożarowymi;

- montaż i konserwacja autonomicznych czujek: tlenku węgla, dymu, ciepła i gazu.

Kwalifikacje w ZSK są odpowiedzią na potrzebę rynkową dotyczącą jakości usług, a ochrona przeciwpożarowa - jak każda branża - wymaga specjalistów mających określone, najwyższe kwalifikacje. Zgłoszone kwalifikacje dotyczące technicznych systemów zabezpieczeń przeciwpożarowych uwzględniają również rozwój tych systemów w zakresie automatyzacji, informatyzacji oraz wynikające z tego tytułu zagrożenia, np. cyberzagrożenia, dla instalacji i systemów przeciwpożarowych

Źródło: Materiały niepublikowane, Jednostka Certyfikująca Usługi CNBOP-PIB.

Kwalifikacje te zostały ogłoszone - obwieszczeniem Ministra Spraw Wewnętrznych i Administracji z dnia 7 maja 2019 r. w sprawie włączenia kwalifikacji rynkowych dotyczących projektowania, montażu i konserwacji zabezpieczeń przeciwpożarowych oraz montażu i konserwacji autonomicznych czujek: tlenku węgla, dymu, ciepła i gazu - do Zintegrowanego Systemu Kwalifikacji.

47 Polska Rama Kwalifikacji (PRK) i Europejska Rama Kwalifikacji (ERK).

Polska Rama Kwalifikacji (PRK) to układ odniesienia dla kwalifikacji nadawanych w Polsce. W PRK jest 8 poziomów. Każdy jest opisywany za pomocą ogólnych charakterystyk zakresu i stopnia skomplikowania wiedzy, umiejętności i kompetencji społecznych, wymaganych od osób posiadających kwalifikacje danego poziomu. W PRK uwzględniono charakterystyki typowe dla kwalifikacji nadawanych w kształceniu ogólnym, zawodowym oraz w szkolnictwie wyższym. Polska Rama Kwalifikacji pozwala na odniesienie polskich kwalifikacji do poziomów Europejskiej Ramy Kwalifikacji (ERK) i poprzez ERK do poziomów kwalifikacji w poszczególnych państwach UE.

48 Zespół ds. doskonałości wdrożeniowej; Przewodniczący: dr Andrzej Krueger, System skutecznego wdrażania nowych technologii, prezentacja z XXVIII Forum Sprawozdawczo-Wyborcze Instytutów Badawczych, Warszawa, 27-28 maja 2019. 
Ponadto należy zwrócić szczególną uwagę na uwarunkowania lokalne lub narodowe, specyficzne i dedykowane poszczególnym regionom, państwom czy kulturom. Aspekt ten jest ważny dla wdrażania nowych rozwiązań, które funkcjonują już w innych państwach, a które zamierzamy wdrożyć w Polsce. Pominięcie tego szczególnego aspektu lub jego niedostateczne uwzględnienie często może skutkować niesatysfakcjonującymi wynikami lub niepowodzeniem wdrożenia.

Duże znaczenie dla innowacyjności ma bez wątpienia sama polityka innowacyjna państwa. Obejmuje ona zestaw instrumentów interwencji publicznych mających na celu wspieranie innowacyjności gospodarki. Na działania interwencyjne składają się różnorodne formy pomocy - między innymi we wprowadzaniu produktów, usług, rozwiązań, technologii, procesów, a także kultury innowacyjnej biznesu ${ }^{49}$. W każdej organizacji niezbędny jest zrównoważony rozwój kluczowych dla jej funkcjonowania obszarów działalności. Do systematycznego i optymalnego osiągania celu zrównoważonego rozwoju organizacji konieczne z kolei są środki, narzędzia i możliwości, a w dzisiejszych czasach w szczególności rozwiązania informatyczne i programowe.

W zależności od pryzmatu patrzenia na określone działanie można je uznać za innowacyjne lub nie. Ważne jest jednak nie to, jak dane działanie będzie postrzegane, ale jakie w praktyce daje korzyści i co jest jego efektem. „(...) Przez innowację rozumie się wprowadzenie do praktyki w przedsiębiorstwie, organizacji, instytucie itp. nowego lub znacząco ulepszonego rozwiązania w odniesieniu do produktu (towaru lub usługi), procesu, marketingu lub organizacji. Istotą innowacji jest właściwe wdrożenie nowości do praktyki...” - taką definicję proponuje R. Kasprzak ${ }^{50}$. Zupełnie inne wyjaśnienie innowacji, nienależące do najbardziej popularnych, w swojej praktyce stosuje autor: jest to produkt, usługa lub rozwiązanie (...), które osiągnęło po wdrożeniu komercyjny sukces lub dało znaczącą korzyść pozamaterialną.

Przywołane opisy prowadzą do stwierdzenia, że innowacja jest to pewien sposób myślenia, oceniania, wnioskowania i działania. Na innowacyjność istotnie wpływają określone uwarunkowania prezentowane wcześniej. Wdrażanie nowych technologii i rozwiązań w ochronie przeciwpożarowej ma niekiedy znamiona działań i produktów innowacyjnych, coraz częściej również nimi jest.

K. B. Matusiak, Budowa powiazań nauki i biznesu w gospodarce opartej na wiedzy, Rola i miejsce uniwersytetu w procesach innowacyjnych, Oficyna Wydawnicza SGH w Warszawie, Warszawa 2010, s. 93. 


\section{Badania i wdrożenia}

W

poniższym rozdziale przedstawiono wybrane zagadnienia dotyczące badań na rzecz bezpieczeństwa i inżynierii środowiska, a także tych poprzedzających oraz wspierających wdrożenia i tworzenie innowacji. Zaliczają się do nich badania naukowe (w tym rozwojowe i prototypowe), a także testowanie kwalifikacyjne wyrobów i systemów. Tę część publikacji poświęcono również tematowi współpracy podmiotów naukowych i biznesowych oraz praktycznej drodze od badań do wdrożeń. Wykorzystano w szczególności wyniki prac i doświadczenia dotyczące wprowadzania nowych rozwiązań w obszarze ochrony przeciwpożarowej. Prezentowane wnioski mogą mieć szersze zastosowanie.

\subsection{Badania naukowe}

Za Encyklopedią PWN badania naukowe to „działalność pracowników, instytucji i organizacji naukowych, prowadzona metodycznie, zgodnie z procedurami dochodzenia do twierdzeń, odkryć i wynalazków, ich weryfikacji i kontroli, przyjętymi w danej dyscyplinie i danej epoce historycznej; podstawowy składnik nauki w aspekcie dynamicznym, czynnościowym. Badania naukowe prowadzi się, biorąc za podstawę: obserwację, pomiar, eksperyment, badania źródeł historycznych i rozważania teoretyczne (rozumowanie indukcyjne i dedukcyjne, stawianie hipotez i dowodzenie), weryfikację i falsyfikację postawionych hipotez, uzasadnianie twierdzeń i budowanie teorii naukowych. W postępowaniu badawczym te różne metody i elementy badań naukowych są wzajemnie powiązane, tworząc historycznie zmienny i stale rozwijający się społeczny system wiedzy. Stanowią one podstawę do prowadzenia teoretycznych badań naukowych i tworzenia teorii naukowych. Ponieważ klasyfikacja nauk i podział nauk na teoretyczne (czyste) i praktyczne (stosowane) są płynne i zmienne, a także upowszechnił się pogląd o wzajemnym przenikaniu się badań teoretycznych i praktycznych, klasyfikację zastąpił podział na typy badań (typologia) z punktu widzenia strategii (celów) badań naukowych ${ }^{1}$. Podział na typy badań naukowych został powszechnie przyjęty i jest stosowany w większości państw na świecie, z pewnymi zmianami, dostosowanymi do struktury i orga-

1 Podział ten wprowadził P. Auger w opracowaniu Aktualne tendencje w badaniach naukowych (1961), wykonanym na zlecenie UNESCO, wyodrębniając podstawowe badania naukowe (wolne i kierowane), stosowane badania naukowe, rozwojowe badania naukowe i wdrożeniowe badania naukowe. 
nizacji instytucji naukowych w poszczególnych państwach. Podstawowe badania naukowe podejmuje się bez praktycznego celu, dla wyjaśnienia zjawisk jeszcze nie zbadanych i odkrycia nowych praw naukowych; stąd też badania naukowe podstawowe nazywa się również teoretycznymi bądź czystymi. Stosowane badania naukowe są zazwyczaj charakteryzowane jako badania naukowe zmierzające do wykorzystania w praktyce wyników badań podstawowych, ich rezultatem są na przykład nowe związki chemiczne, prototypy, modele itp., które powstają i są sprawdzane w laboratoriach pod względem efektywności, walorów technicznych i użyteczności. Wdrożeniowe badania naukowe polegają na opracowaniu metod i technik zastosowania wyników badań stosowanych w produkcji, są końcowym etapem cyklu badawczego od odkrycia (wynalazku) do praktycznego jego zastosowania, obejmują one przeniesienie wyników badania naukowych stosowanych z laboratoriów do przemysłu, z fazy modeli i prototypów do fazy produkcji masowej (opracowywanie nowych metod wytwarzania, prace projektowe, konstrukcyjne, przygotowanie serii doświadczalnych wyrobów w skali przemysłowej). Rezultaty tych badań nazywane są w zależności od ich znaczenia również innowacjami. Wdrożeniowe badania naukowe wiążą się ściśle z tzw. pracami rozwojowymi (stanowiącymi ich element), polegającymi na adaptacji metod i osiągnięć badań wdrożeniowych do warunków produkcji w danym państwie u jego producenta oraz na dostosowaniu produktu do wymogów odbiorcy i jego rynku"2.

Wszystkie te typy badań naukowych - stosowane, rozwojowe i wdrożeniowe - wykorzystywane w różny sposób i w różnym stopniu odnaleźć można w procesie wdrażania wyrobów i rozwiązań na cele bezpieczeństwa pożarowego. Wśród prowadzonych badań ważną rolę odgrywają między innymi te z zakresu bezpieczeństwa. A. Czupryński zauważa, iż do bezpieczeństwa możemy podejść w ujęciu pozytywnym i negatywnym. Podejście pozytywne opisuje przedmiot zainteresowania i wskazuje kierunek jego rozwoju, negatywne zaś opiera się na postrzeganiu bezpieczeństwa jako przeciwieństwa zagrożeń. Zagrożenie i bezpieczeństwo to pojęcia antonimiczne, które wzajemnie się określają. Nie oznacza to jednak, że brak zagrożenia powinien powodować rezygnację z rozwoju bezpieczeństwa. Brak określonego zagrożenia lub systematyczne obniżanie się poziomu bezpieczeństwa powinno spowodować intensyfikację wysiłków w innych obszarach istotnych dla przetrwania i rozwoju podmiotu bezpieczeństwa. Dodatkowo naiw-

2 Badania naukowe, Internetowa encyklopedia PWN, https://encyklopedia.pwn.pl/haslo/badania-naukowe;3946184. html [dostęp: 1.03.2020]. 
nością jest sądzić, że bezpieczeństwo będzie budowane w oderwaniu od potencjalnych, realnych i hipotetycznych zagrożeń3

\subsection{Badania bezpieczeństwa pożarowego}

Według S. Kozieja bezpieczeństwo i rozwój to dwa podstawowe wymiary istnienia jednostek i całych społeczności, w tym społeczności zorganizowanych w państwa lub organizacje międzynarodowe. Te dwa wymiary wzajemnie się warunkują: bez bezpieczeństwa nie można marzyć o rozwoju, rozwój zaś ułatwia zapewnianie bezpieczeństwa. Fundamentem w tym duecie jest bezpieczeństwo. Takie relacje przesądzają także o wzajemnych zależnościach między strategiami bezpieczeństwa i rozwoju4.

Powyższe stwierdzenia mają swoje odzwierciedlenie i uzasadnienie w obszarze badań i wdrożeń dotyczących bezpieczeństwa pożarowego. Przede wszystkim rozwój stosowanej techniki i technologii dla działań prewencyjnych i samej walki z pożarami warunkowany jest bezpieczeństwem użycia tych technicznych zabezpieczeń przeciwpożarowych czy sprzętu i wyposażenia straży pożarnej. Bezpieczeństwo wyrobu (sprzętu i wyposażenia) stosowanego przez ratownika jest priorytetem wynikającym nie tylko z wymagań prawnych5, ale także warunkującym zaufanie do tych rozwiązań. Zatem uzasadniona i prawdziwa jest teza S. Kozieja, iż w szerokim rozumieniu bezpieczeństwo jest fundamentem do rozwoju. Rozważania te nabierają szczególnego znaczenia w powiązaniu z prezentowanymi w rozdziale drugim zagadnieniami dotyczącymi budowania zaufania do wyrobów i rozwiązań stosowanych na rzecz bezpieczeństwa pożarowego, a także potrzebnego do tego - często dedykowanego i indywidualnego - ekosystemu umożliwiającego tworzenie i wdrażanie nowych rozwiązań i produktów.

Natomiast B. Wiśniewski w publikacji Bezpieczeństwo $w$ teorii $i$ badaniach naukowych twierdzi, iż odpowiedzialność za bezpieczeństwo spoczywa na wszystkich. Autor wskazuje na szczególną odpowiedzialność w tym zakresie pracowników naukowych i naukowo-dydaktycznych. Podkreśla, iż badacze bezpieczeństwa korzystają z osiągnięć wielu dziedzin, dyscyplin naukowych. Współczesne i pro-

3 A. Czupryński, Bezpieczeństwo w ujęciu teoretycznym, w: Bezpieczeństwo, teoria-badania-praktyka, A. Czupryński, B. Wińsniewski, J. Zboina, Wydawnictwo CNBOP-PIB, Józefów 2015, s. 10.

4 S. Koziej, Bezpieczeństwo: istota, podstawowe kategorie i historyczna ewolucja, „Bezpieczeństwo Narodowe” 2011, 2, 19-39.

5 Zagadnienia dotyczący roli i znaczenia oceny zgodności dla zapewnienia oczekiwanego poziomu bezpieczeństwa dla ratowników i ratowanych, a także spełnienia wymagań podstawowych (w tym w zakresie bezpieczeństwa pożarowego) w obiektach budowalnych jest prezentowane szeroko w innych publikacjach autora. Podejście to jest powszechne i stosowane w państwach na całym świecie. Jest to zagadnienie niezwykle ważne, czasem - niestety - niewłaściwie rozumiane, interpretowane i oceniane w naszym kraju. 


\section{Badania i wdrożenia | Badania bezpieczeństwa pożarowego}

gnozowane zagrożenia godzące w bezpieczeństwo wymuszają prowadzenie intensywnych badań nad źródłami ich powstawania, skutecznymi formami i metodami ich wykrywania, monitorowania, ograniczania oraz ewentualnego likwidowania skutków ich wystąpienia. Zagrożenia te wymuszają dodatkowo konieczność upowszechniania wiedzy o bezpieczeństwie ${ }^{6}$.

Badania bezpieczeństwa pożarowego prowadzone są przez podmioty i pracowników naukowych. Przedmiotem dociekań i rozważań są różne aspekty bezpieczeństwa pożarowego. W tym obszarze widać wyraźnie potrzebę wspierania poszukiwań oraz wdrożeń nowych rozwiązań i produktów, zarówno w zakresie technicznym, jak i organizacyjnym. Wielokrotnie te zakresy muszą być ściśle powiązane?.

W prowadzonych dotychczas badaniach naukowych nad bezpieczeństwem pożarowym do interpretacji wyników i ich praktycznego zastosowania w procesie rozwiązywania konkretnych problemów autor niniejszej monografii wykorzystywał zdobyte doświadczenie zawodowe. Badania te uwzględniały szersze postrzeganie bezpieczeństwa i służyły poszukiwaniu kierunków i rozwiązań dotyczących optymalizacji, doskonalenia i zmian w ochronie przeciwpożarowej. Również te badania i doświadczenia potwierdzają tezę B. Wiśniewskiego dotyczącą konieczności permanentnego pozyskiwania wiedzy i jej upowszechniania, a także lepszego i szerszego niż dotychczas wykorzystywania w praktyce wszystkich działań ochrony przeciwpożarowej (zarówno tych prewencyjnych, ratowniczych, jak i z obszaru profilaktyki i edukacji społecznej).

Dlatego zasadnicze i wciąż aktualne w badaniach nad bezpieczeństwem pożarowym są pytania o to, jak skuteczniej chronić (zdrowie, życie, mienie, środowisko) i jak zapewnić ciągłość działania. Analiza wyników prowadzonych badań uprawnia do wniosku o zasadności stosowania terminu projektowanie bezpieczeństwa w szerszym niż dotychczas zakresie. Obecnie sprzyja temu intensywny rozwój techniki i nowych technologii, które znajdują coraz szersze zastosowanie w obszarze bezpieczeństwa pożarowego. Wieloletnie doświadczenia autora związane z badaniami oraz oceną zgodności wyrobów i ich zestawów wykorzystywanych w ochronie przeciwpożarowej pozwalają na formułowanie wniosków dotyczących zasadności podejścia projektowego nie tylko do zagadnień stosowania wyrobów. Stwierdzić można, iż aktualnie pojęcie projektowania jest powszechnie używane przede wszystkim w odniesieniu do technicznych systemów zabezpie-

6 B. Wiśniewski, Bezpieczeństwo w teorii i badaniach naukowych, Wydawnictwo WSPoL, Szczytno 2011, s. 5-8.

7 Na przykład nowe urządzenie gaśnicze wraz z techniką gaszenia, uwzględniającą zalety i wady rozwiązania. 
czeń przeciwpożarowych. Inżynierowie bezpieczeństwa pożarowego oraz projektanci urządzeń przeciwpożarowych korzystają obecnie z modeli komputerowych w procesie projektowania. Symulacje te pozwalają w wielu przypadkach na optymalizację projektu i dostosowanie zakładanych parametrów do indywidualnych potrzeb czy wymagań. Działania te nadal stanowią jednak tylko pewne uzupełnienie dla projektowania w oparciu o podstawy formalne, dokumenty normatywne, zasady wiedzy technicznej i obliczenia ${ }^{8}$. Natomiast stosowanie pojęcia projektowania bezpieczeństwa pożarowego w odniesieniu do działań ratowniczych czy profilaktyki i edukacji społecznej jest nowym kierunkiem w naszym kraju. Temu procesowi towarzyszy poszukiwanie praktycznych narzędzi, co wyjaśniono we wcześniejszych rozdziałach. W obszarze bezpieczeństwa pożarowego najbardziej uzasadnione jest zatem używanie pojęcia projektowania w odniesieniu do działań i rozwiązań prewencyjnych (stosowania czynnych i biernych zabezpieczeń przeciwpożarowych). Coraz wyraźniej dostrzec można potrzebę poszukiwania rozwiązań umożliwiających projektowanie bezpieczeństwa pożarowego w obszarze działań ratowniczych oraz profilaktyki i edukacji społecznej. Do faktycznej potrzeby poszukiwania wdrożeń i rozwiązań w tych obszarach działań na rzecz ochrony przeciwpożarowej przekonały autora badania i prace rozwojowe, w których próbowano ujawnić nowe możliwości wykorzystania technologii IT do optymalizacji rozmieszczenia zasobów ludzkich (ratowników), ich sprzętu i wyposażenia tak, aby dostępność usługi ratowniczej, przez nich świadczonej, była większa. Wyniki badań, a także produkt projektu (oprogramowanie) ${ }^{9}$ prowadzą do wniosku, iż stosowanie pojęcia projektowanie jest uzasadnione. Zdaniem autora zagadnienia projektowania, zarządzania zasobami i optymalizacji na rzecz większej dostępności usługi ratowniczej będzie miało coraz większe znaczenie dla rozwoju i bezpieczeństwa pożarowego w najbliższej przyszłości. Służą temu badania, w tym współpraca na gruncie nauki i praktyki ${ }^{10}$.

\subsection{Współpraca nauka i biznes}

Przykłady współpracy zakończonej wdrożeniami przedstawiono między innymi w odrębnej publikacji Bezpieczeństwo pożarowe. Rozważania na gruncie nauki i praktyki11. Jednym z nich jest wdrożenie rozwiązania w wyniku współpracy

8 A. Krauze, Komputerowe modele rozprzestrzeniania się płomieni i gaszenia woda, w ocenie skutków rozwoju pożaru oraz skuteczności działania instalacji tryskaczowych, „Zeszyty Naukowe SGSP” 2019, 72(4), s. 42-54.

9 J. Zboina, J. Kielin, Projektowanie systemu ratowniczego, dz. cyt.

10 J. Zboina, Bezpieczeństwo pożarowe, rozważania na gruncie nauki i praktyki, dz. cyt.

11 Tamże. 
kilku podmiotów (instytutu badawczego, podmiotu biznesowego, właściciela obiektów budowalnych i jednostek Państwowej Straży Pożarneje ${ }^{12}$ ). Stanowi ono odpowiedź na konkretny, zdefiniowany problem z praktyki, jakim jest zapewnienie ratownikom dostępu do chronionego obiektu budowlanego w sytuacji uruchomienia się systemu sygnalizacji pożarowej, podczas gdy personel tego obiektu jest nieobecny. W wyniku współpracy wskazanych powyżej podmiotów każdy z partnerów miał swoją „rolę”, czyli konkretne zadania (wkład). Jako uczestnik opisywanego projektu i procesu wdrożenia rozwiązania (od samego początku), autor czuje się upoważniony do wniosku, iż nikt z partnerów nie byłby w stanie wypracować samodzielnie rozwiązań organizacyjnych i technicznych stanowiących odpowiedź na ten konkretny problem. Innym przykładem współpracy jednostek naukowych i biznesowych mogą być wspólnie realizowane projekty finansowane zewnętrznie, zarówno te wygrywane w ramach krajowych ${ }^{13}$ i międzynarodowych ${ }^{14}$ konkursach, jak i zlecane bezpośrednio przez podmioty komercyjne. Poświęcone są one rozwiązaniu określonego problemu, opracowaniu rozwiązania lub produktu.

Poza już ugruntowanymi, przywołanymi formami współpracy, autor miał okazję wiele razy dyskutować i poszukiwać możliwie najlepszych nowych pomysłów na nową i efektywną współpracę tych podmiotów (wnioski przedstawiono w rozdziale drugim). Poniżej dodatkowo zaprezentowane zostały inne, cenne i ważne dla tego obszaru aktywności, badania i wnioski.

W ramach badania Skuteczna wspótpraca nauka-biznes w opinii przedsiębiorców powstały konkluzje i rekomendacje, które zawarto w raporcie ${ }^{15}$ pod tym samym tytułem. Czytamy w nim między innymi, iż ocena dotychczasowej współpracy i zaawansowania wdrożeniowego rozwiązań proponowanych przez naukowców

12 Tamże, s. 110-117.

13 Na przykład: 1) Projekt pt. Program do oceny ryzyka wystapienia awarii w obiektach przemysłowych stwarzajacych zagrożenie poza swoim terenem, finansowany przez NCBR, realizowany przez konsorcjum jednostek naukowych: Lider - CNBOP-PIB, Narodowe Centrum Badań Jądrowych, Politechnika Warszawska i partner technologiczny firma BERA Systems Sp. z o.o.; 2) Projekt pt. Symulator szkoleniowy w zakresie wykorzystania technicznych systemów przeciwpożarowych wspierających ewakuację ludzi z obiektów budowlanych, finansowany przez NCBR, realizowany przez konsorcjum jednostek naukowych: Lider - CNBOP-PIB, SGSP i Advisio Poland Sp. z o.o.

14 Na przykład: 1) Projekt pt. Adapted situation awareness tools and tailored training scenarios for increasing capabilities and enhancing the protection of first responders (ASSISTANCE), finansowany w ramach programu Horyzont 2020 Unii Europejskiej, realizowany przez 18 podmiotów z Europy, z liderem Univesitat Politecnica de Valencia. Jednym z konsorcjantów jest CNBOP-PIB.

15 A. Wycisk, M. Płaszczyca, Skuteczna wspótpraca nauka-biznes w opinii przedsiębiorców. Raport, Dział Badań i Analiz CZIiTT PW, Warszawa 2019.

* Badanie zrealizowane przez Dział Badań i Analiz Centrum Zarządzania Innowacjami i Transferem Technologii Politechniki Warszawskiej na zlecenie Inventity Foundation na potrzeby projektu Centrum Brokeringu Technologii-pomostem do innowacji, finansowanego przez Ministra Nauki i Szkolnictwa Wyższego w ramach programu „DIALOG”. 
jest dobra lub raczej dobra. Przedsiębiorcom zależy na wspieraniu naukowców w taki sposób, by mogli z coraz większą łatwością i trafnością współpracować ze światem biznesu. W raporcie uwzględniono także następujące spostrzeżenia: „Sukces współpracy nauka-biznes zależy od konkretnego przypadku: częściej zdarzają się rozwiązania spełniające oczekiwania biznesu, ale bywają i takie, które wymagały sporo dodatkowej pracy. Jednocześnie, przedsiębiorcy podkreślają, że niski poziom gotowości technologicznej nie jest sytuacją jednoznacznie negatywną, ponieważ dzięki temu możliwe jest wspólne doskonalenie rozwiązania. Propozycje naukowców często są zbyt wysokiej jakości, opracowane zgodnie z najwyższymi standardami naukowymi, co jednak powoduje, że są kosztowne i w efekcie przekraczają zarówno możliwości przedsiębiorcy w zakresie wdrożenia, jak i rynku w zakresie możliwości nabywczych odbiorcy końcowego”. Powyższe stwierdzenia wydają się niezwykle istotne. Wyrażane opinie należą raczej do rzadkich, ponieważ odnoszą się do ograniczeń również po stronie przedsiębiorców. Badana grupa dostrzegła także problemy, które szczegółowo wskazano na przykładach w rozdziale drugim. Z opinii przedsiębiorców wynika ponadto, iż:

- wśród naukowców brakuje doświadczenia w przemyśle, stąd biorą się trudności w odnalezieniu się w warunkach konkurencji na rynku;

- do współpracy dochodzi najczęściej z inicjatywy firm, przy czym dużą trudnością jest znalezienie właściwego naukowca - specjalisty gotowego podjąć się prac wdrożeniowych;

- relacje z uczelnią utrudniają przede wszystkim czasochłonne i skomplikowane formalności po stronie jednostki naukowej (wydłużony proces decyzyjny, wielość komórek uczelni zaangażowanych w działanie, trudność w uzgodnieniu warunków współpracy);

- barierą są też pewne ograniczenia prawne po stronie jednostek naukowych (np. niemożliwość skorzystania przez przedsiębiorstwo z części infrastruktury jednostki naukowej);

- przeszkodą bywają wysokie koszty prowadzenia prac B+R, które przekraczają możliwości własne podmiotów gospodarczych, a zewnętrzne dofinansowanie stanowi tylko pewien procent całościowych kosztów, natomiast skomplikowane i czasochłonne procesy aplikowania o środki zewnętrzne i rozliczania ich nie zachęcają do korzystania z tej formy finansowania;

- tendencja postrzegania wdrożenia jako elementu, za który odpowiada głównie przedsiębiorca, również nie zachęca przedsiębiorców do współpracy;

- ponadto rozwiązania proponowane przez naukowców nie zawsze charakteryzują się wysokim poziomem gotowości wdrożeniowej - mimo iż doskonałe 
naukowo, bywają niepraktyczne i oderwane od rzeczywistości rynkowej. Powodem tego w opinii przedsiębiorców może być niewystarczające doświadczenie naukowców w pracy w przemyśle oraz rozbieżność celów naukowych i wdrożeniowych, nie sprzyjająca łączeniu obowiązków w jednostce naukowej i przedsiębiorstwie. Główne bariery z perspektywy naukowca wpisane są w system oceny kariery naukowej, budowany na działaniach stricte naukowych;

- czas naukowców zajmują również obowiązki dydaktyczne; staż w przemyśle nie jest obowiązkowym elementem kariery naukowej ${ }^{16}$.

Powyższe wnioski nie budzą wątpliwości co do trafności diagnozy. W ocenie autora są niestety częściowo błędne, bo jednostronne. Kwestię tę wyjaśniono w rozdziale drugim. Trudno zgodzić się z twierdzeniem, iż przeszkodą dla efektywnej współpracy pomiędzy światem nauki i biznesu jest to, że czas naukowców zajmują również obowiązki związane z nauczaniem. Uczelnia, która nie prowadzi dydaktyki staje się bowiem całkowicie inną organizacją. Problem tkwi zupełnie gdzie indziej. Uczelnie prowadzą aktualnie przede wszystkim proces dydaktyczny oraz badania naukowe. Część z tych instytucji posiada ponadto określoną ofertę dla biznesu w zakresie badań, usług i współpracy na rzecz wdrożeń. Ta oferta się zmienia. Jej aktualizacja powinna uwzględniać komunikację, budowanie relacji, rozumienie zmieniających się potrzeb, możliwości i ograniczeń stron. Można zatem skonstatować, iż bez ciągłej pracy nad dostosowaniem i doskonaleniem ofert stron (choćby zwolnienie pracowników naukowych z części obowiązków dydaktycznych) nie wzrośnie efektywność działań na rzecz wdrożeń z biznesem.

Pomoc stanowić może dodatkowo zbiorcza analiza potrzeb i oczekiwań sformułowanych przez przedsiębiorców, przedstawiona w dalszej części przywołanego raportu. Dotyczy ona idealnych warunków współpracy, form wspierania naukowców oraz rozwiązań wzmacniających skłonność biznesu do inwestowania. Zapisano je jako zbiór rekomendacji:

„Naukowiec pracujacy przy wdrożeniu posiada doświadczenie zdobywane bezpośrednio $w$ pracy w przedsiębiorstwach, np. staż po doktoracie bądź też pośrednio, podczas realizacji badań na zlecenie podmiotu komercyjnego".

Komentarz autora: Doświadczenie w tym zakresie naukowiec może zdobyć tylko poprzez praktyczną współpracę, konkretne działania. Często pomiędzy podmiotami naukowymi i biznesowymi pojawiają się istotne rozbieżności w ocenie warunków i możliwości współpracy. Trzeba je ujawnić i poszukiwać kompromisu.

16 Tamże, s. 33-38. 


\section{Badania i wdrożenia | Współpraca nauka i biznes}

„Znajomość rynku pozwala lepiej zrozumieć potrzeby i realia funkcjonowania biznesu. $W$ konsekwencji proponowane rozwiąania uwzględniaja potencjat przedsiębiorstwa (technologiczny, finansowy, kadrowy), możliwa jest też integracja proponowanych rozwiąań z aktualnymi możliwościami partnera biznesowego - od fazy koncepcyjnej po wdrożenie".

Komentarz autora: Podstawą współpracy jest niezębna wiedza oraz akceptacja możliwości i ograniczeń partnera. Strony nie muszą posiadać jednakowej wiedzy. Znajomość rynku to zwykle domena biznesu i naukowcom trudno będzie to zmienić. Oczywiście możliwe i zrozumiałe jest oczekiwanie, iż naukowcy muszą lepiej rozumieć potrzeby rynku. Jednak różnorodne postrzeganie jest raczej wartością niż wadą, jedynie trudniej zarządzać współpracą takiej grupy. Ma ona jednak wówczas znacznie większy potencjał i możliwości - czerpane właśnie z rozbieżności postrzegania. Dlatego kluczowe jest precyzyjne ustalenie oczekiwanych celów, wyników i zakresu współpracy. Ten etap - w ocenie autora - jest słabością nie tylko jednostek naukowych. Praktyczny problem występuje, kiedy przedsiębiorca nie potrafi określić jakiej usługi, współpracy oczkuje od jednostki naukowej. Dopiero taka informacja pozwala drugiej stronie na przedstawienie swojej oferty, co prowadzi do ustalenia jej zakresu bądź odstąpienia od współpracy w danej chwili. „Wspótpraca jest ścisła i obejmuje sprawna i wartościowa komunikację, której nieodzownym elementem sa częste, regularne spotkania przedstawicieli biznesu i nauki. Podczas spotkań roboczych dochodzi do rzeczowej wymiany informacji o prowadzonych pracach, potrzebach, ograniczeniach, problemach, możliwych do realizacji projektach".

Komentarz autora: W ocenie autora to trafna rekomendacja, często realizowana w praktyce. Spotkania to nie cel, ale narzędzie do skutecznej komunikacji i budowania relacji partnerów. Strony koniecznie muszą ustalić ich standard, częstotliwość i zakres. Z własnych doświadczeń autor dodałby, iż konieczne jest dokumentowanie i egzekwowanie uzgodnień z tych spotkań. Pożądany jest partnerski model relacji (podmioty biznesowe mają czasami trudności z wychodzeniem z roli klienta). Bez egzekwowania i realizacji uzgodnień oraz omawiania problemów celem bliższym do osiągnięcia w perspektywie czasu - zamiast efektywnej współpracy na rzecz wdrożeń - staje się „familijność”.

„Działania wdrożeniowe naukowców są uwzględniane w ich karierze jako istotne osiagnięcia, które mają odzwierciedlenie w motywacji finansowej do kolejnych aktywności $w$ tym obszarze. Naukowcy wspótpracujący z biznesem na czas pracy wdrożeniowej maja zreorganizowane inne obowiązki (np. dydaktyczne) w sposób nie powodujacy obciażeń nadmiarem pracy”. 
Komentarz autora: Autor podziela opinie o potrzebie rozwoju oraz zachęcania i motywowania naukowców do udziału we wdrożeniach. Rekomendacja jest trafna, ale nie wskazuje szczegółowych rozwiązań. Zwolnienie naukowców z obowiązków dydaktycznych czasowo może przynosić korzyści. Autor nie podziela opinii twórców raportu co do celowości ujęcia tej kwestii systemowo. Takie podejście nie będzie skutkowało wzrostem liczby wdrożeń. Kwestię wyjaśniono już powyżej. „Wspótpraca jest utrzymywana przez cały okres wdrożenia, w projekcie i po jego zakończeniu obowiazuje wspótdzielenie odpowiedzialności za opracowane rozwiąanie (dostępność naukowców po wdrożeniu, rozwiąywanie potencjalnych problemów)"’17.

Komentarz autora: To faktycznie bardzo trafna rekomendacja. Z praktyki autora wynika, iż cel ten najczęściej jest osiągany przy wspólnych wdrożeniach realizowanych $\mathrm{w}$ ramach finansowania zewnętrznego projektów. Co więcej precyzyjnych uzgodnień wymaga nie tylko zakres odpowiedzialności, ale również korzyści partnerów.

W szczegółowo cytowanym i analizowanym raporcie zawarto również cenne i trafne wskazówki dotyczące idealnych - w opinii przedsiębiorców - warunków współpracy z jednostkami naukowymi. Poniżej przedstawiono najistotniejsze z nich wraz z komentarzami autora. Przedsiębiorcy przede wszystkim postulują o:

1) uproszczone procedury w jednostkach naukowych i krótszy czas niezbędny do nawiązania lub kontynuacji współpracy;

2) czytelną, przejrzystą ofertę świata naukowego skierowaną do biznesu, akcentującą potencjał naukowo-badawczy zespołów mogących podjąć współpracę wdrożeniową;

3) aktywne odpowiadanie jednostek naukowych na potrzeby biznesu;

4) większą elastyczność jednostek naukowych w rozliczeniach finansowych, w tym w realnym ustalaniu wartości usług;

5) kształcenie wykwalifikowanej kadry technicznej, zarówno inżynierów, jak i techników; system nauczania oparty w większym stopniu na umiejętności wykorzystania wiedzy w praktyce (warsztaty, ćwiczenia, praktyki, laboratoria);

6) wzajemną pomoc w zakresie komercjalizacji poprzez wspólną promocję wyników współpracy podczas wydarzeń biznesowych, takich jak targi, konferencje, seminaria, sympozja;

7) opracowanie i regularne korzystanie z narzędzi do przepływu informacji (uwzględniającego pomysły i potrzeby biznesu, możliwości poszczególnych zespołów naukowych oraz realizowane badania i projekty), np. wspólnej bazy jednostek

17 Tamże, s. 33-38. 
naukowych i firm wyrażających gotowość współpracy w formie portalu internetowego opracowanego lub zarządzanego przez instytucję centralną, co gwarantowałoby aktualność, kompletność, bezpieczeństwo danych i zaufanie użytkowników. Ponadto najskuteczniejsze jest w opinii przedsiębiorców finansowanie projektów ze środków publicznych (najczęstsze źródło: NCBR). Duże korzyści we współpracy przynosi również udział w konferencjach, targach, udostępnianie zaplecza kadrowego i infrastrukturalnego przez jednostki naukowe, praktyka badawcza i wdrożeniowa oparte na przepływie kadry (realizacja doktoratów, wzajemne szkolenia, staże, praktyki, wizytacje). Zwracają oni uwagę także na efektywne korzystanie z modelu finansowania proponowanego w konkursach strategicznych programów badań naukowych i prac rozwojowych NCBR oraz w ramach funduszy europejskich z naciskiem na Horyzont 2020, bony na innowacje, szybkie ścieżki. Przedstawiciele biznesu chętnie korzystają z tych narzędzi, ponieważ motywują one obie strony relacji do współpracy na zasadach partnerskich (jasno określone zadania, możliwość osiągnięcia sukcesu tylko poprzez współpracę) i zabezpieczają realizację działań B+R, która przez świat biznesu postrzegana jest jako ryzykowna. Dzięki tak prowadzonej współpracy dochodzi do wymiany wiedzy, budowania relacji, zaznajomienia z wzajemnymi potrzebami i możliwościami, realizacji wspólnych przedsięwzięć ${ }^{18}$.

Kluczowe są pierwsze 4 postulaty. Postulat 5 odnosi się do potrzeb przedsiębiorców w kontekście kształcenia i umiejętności formalnych personelu. Jest ważny nie wprost dla współpracy nauka - biznes, ale dla lepszego funkcjonowania podmiotów. W odniesieniu do treści postulatów 6 i 7 w ocenie autora potrzeba jedynie większej determinacji i działań na rzecz ich realizacji. Kolejne przytoczone powyżej stwierdzenia przedsiębiorców odnoszą się do instrumentów finansowych i wniosków o ich kontynuację z uwzględnieniem wskazanych aspektów. Nie sposób odmówić słuszności końcowej konkluzji raportu, iż problem stanowi nie sam katalog dostępnych, znanych i stosowanych narzędzi, ale sposób ich wykorzystania - w większości przypadków za mało nastawiony na praktykę. Obecnie największym wyzwaniem jest nie tyle zachęcanie do podejmowania współpracy, ale jej praktyczna realizacja: zdobycie środków finansowych na badania, przebrnięcie przez wymagane procedury i dokumentację, przygotowanie rynkowego rozwiązania, przeprowadzenie wdrożenia, rozliczenie projektu i podtrzymanie relacji w przyszłości ${ }^{19}$.

18 Tamże, s. 33-38.

19 A. Wycisk, M. Płaszczyca, Skuteczna wspótpraca nauka-biznes w opinii przedsiębiorców, dz. cyt.,s. 33-36. 


\subsection{Od badania do wdrożenia}

E. Effron w publikacji pod tytułem Skup się na tym, co możesz zmienić (i zignoruj cała resztę ${ }^{20}$ proponuje podejście do efektywniejszego osiągania celów w ośmiu krokach. Autor wyjaśnia na podstawie prowadzonych badań i doświadczeń, dlaczego takie właśnie podejście jest uzasadnione, skuteczne i uniwersalne. Proponowane kroki to odpowiednio ${ }^{21}$ :

1) ustal ambitne cele (jak ustalić cele prowadzące do znakomitych wyników);

2) zachowuj się odpowiednio (zachowania takie dają lepsze wyniki w określonych sytuacjach);

3) rozwijaj się szybciej (jak najszybciej rozwijać najważniejsze zdolności);

4) nawiązuj kontakty;

5) maksymalizuj dopasowanie;

6) udawaj (dlaczego czasem nie powinieneś być sobą?);

7) zaangażuj ciało (dbaj o nie, by osiągać najlepsze wyniki);

8) unikaj zakłóceń (przeszkadzających w uzyskaniu wyników).

Autor przekonuje, iż choć tak usystematyzowane podejście nie jest nowe, w praktyce udowodniono jego skuteczność. W przywołanych badaniach wykazano, iż metoda 8 kroków jest efektywna. Wyzwanie stanowi to, że bardzo niewiele osób i firm zna wszystkie te kroki i potrafi je realizować.

To uniwersalne i biznesowe podejście może mieć szerokie zastosowanie. Zapewne sprawdzać się może również w badaniach, współpracy i wdrożeniach w ochronie przeciwpożarowej. W rozmowach autora z partnerami biznesowymi, którzy wprowadzają nowe rozwiązania i produkty w obszarze bezpieczeństwa pożarowego, powtarzają się pewne stwierdzenia. Ich metody są różne, ale często w drodze do wdrożeń pojawia się potrzeba badań i współpracy ze środowiskiem naukowym w szerszym niż dotychczasowy zakresie. Dostosowanie się do dynamicznie zmieniających się zagrożeń i potrzeb jest dużym wyzwaniem dla wszystkich. Dlatego uzasadniona wydaje się teza, iż nie ma jednej standardowej drogi od pomysłu poprzez badania do wdrożenia. Wskazać można oczywiście powtarzalne elementy, lecz obecnie sam proces wdrożenia posiada określone zindywidualizowane cechy, które decydują o jego skuteczności. Wyzwaniem jest pozyskiwanie i praktyczne wykorzystywanie na rzecz bezpieczeństwa pożarowego wiedzy na temat nowych rozwiązań i wdrożeń.

\footnotetext{
20 E. Effron, 8 kroków do wyższej efektywności. Skup się na tym, co możesz zmienić (i zignoruj cała resztę), Wydawnictwo ICan Institute 2019.

21 Tamże, s. 15.
} 
A. Krakowski w artykule pod tytułem Most między nauką a biznesem zauważa, że „współpraca między nauką a biznesem w dalszym ciągu wymaga poprawy, by polska gospodarka mogła stale zwiększać swoją konkurencyjność. Jednak wymogi współczesnego biznesu sprawiają, że obydwa środowiska są praktycznie skazane na współpracę i rzeczywiście coraz częściej się na nią decydują”22. Autor stawia ciekawą tezę, iż każdy, kogo interesuje tematyka współpracy nauki i biznesu w Polsce, przyzwyczaił się do zwyczajowego narzekania obu stron na niezrozumienie wzajemnych potrzeb i specyfiki. Prezentowane twierdzenia są zasadniczo zgodne z innymi przywołanymi już w przedmiotowej publikacji opiniami i wnioskami z badań. Interesujące natomiast myśli A. Krakowski zamieścił w części pod tytułem Od zmian do innowacji. Stanowią one pewien głos w dyskusji dotyczącej pytania o to, jak skuteczniej wdrażać. Autor wychodzi od tezy P. Druckera, iż „zadaniem biznesu jest przekształcenie zmian w innowacje, a więc w nowy biznes”. Wskazuje na ważną rolę państwa , które prowadzi do dynamicznego rozwoju rynku innowacji, m.in. udzielając odpowiedniego wsparcia dla biznesu. W dalszej części swoich rozważań A. Krakowski przywołuje trudności w porozumieniu się między światami nauki i biznesu, wskazane w raporcie Społeczne oblicze innowacji. Jak wspierać postawy innowacyjne i promować etos innowatora? ${ }^{23}$ Należą do nich: brak wiedzy na temat możliwości współpracy nauki i biznesu, brak atrakcyjnej oferty uczelni, przerost formalności i biurokracji lub niewystarczająca motywacja finansowa do podjęcia współpracy, odmienne podejście do czasu i kosztów, a także inne cele czy brak wzajemnego zaufania środowisk akademickich i biznesowych. Nie pomaga również słabo rozwinięte otoczenie pośredniczące w transferze technologii. Obserwacje te prowadzą do konkluzji, iż jeśli Polska ma awansować w rankingach innowacyjności, dystans dzielący światy nauki oraz biznesu powinien być konsekwentnie zmniejszany. Autor szansy na przyszłość upatruje w przezwyciężeniu historycznej nieufności dwóch światów - nauki i biznesu. W Polsce wciąż pozostaje wiele do zrobienia, by pogłębić wzajemne kontakty firm i ośrodków naukowych i dzięki efektowi synergii wykorzystać tkwiący w nich potencjał. Szansa leży przede wszystkim w wykorzystywaniu naukowo ugruntowanej, empirycznej wiedzy na temat rynku. We wszystkich obszarach trudno jest odnieść sukces bez wsparcia biznesu przez środowiska naukowe. Współpraca nauki i biznesu

22 A. Krakowski, Most między nauką a biznesem, portal internetowy Ican Institute, https://www.ican.pl/a/most-miedzy-nauka-a-biznesem/DdCGfxvco [dostęp: 8.03.2020].

23 Społeczne oblicze innowacji. Jak wspierać postawy innowacyjne i promować etos innowatora?, J. Górski, A. Mikołajczyk, M. Tataj (red.), Fundacja Polskiego Godła Promocyjnego, Warszawa 2016, https://mli.org.pl/upload/files/Raport_MLI_ ebook2.pdf [dostęp: 8.03.2020]. 


\section{Badania i wdrożenia | Wnioski}

ma nadal duży - nie zawsze ujawniony - potencjał, dlatego rosną wysiłki obliczone na zacieśnianie dotychczasowych kontaktów między oboma środowiskami. Świadomość obszarów wymagających poprawy (wykazanych m.in. w raporcie Deloitte czy też danych GUS ilustrujących wzrost wydatków na B+R w Polsce) daje nadzieję, że w przyszłości światy nauki i biznesu będą się do siebie zbliżać, a nie oddalać. Jeśli przyjąć dane finansowe udostępnione przez GUS czy NCBR za miernik stanu współpracy między nauką a biznesem, można dostrzec, że od pewnego czasu dystans między tymi środowiskami ulega skracaniu²4.

\subsection{Wnioski}

Zasadne i wciąż aktualne w badaniach nad bezpieczeństwem pożarowym są pytania o to, jak skuteczniej chronić zdrowie, życie, mienie, środowisko, a także jak zapewnić ciągłość działania. Stałą potrzebą jest poszukiwanie odpowiedzi i konkretnych rozwiązań w tym zakresie. W procesie badawczym konieczne jest uwzględnianie zmienności zagrożeń, tj. ewolucji znanych i pojawiania się nowych, dotychczas niespotykanych. Badania naukowe, projekty badawczo-rozwojowe, prace analityczne i planistyczne, a także omawiane wdrożenia i innowacje odgrywają kluczową rolę w procesie optymalizacji, doskonalenia, dostosowywania i wprowadzania koniecznych zmian w zakresie ochrony przeciwpożarowej ${ }^{25}$.

Rozwiązania w zakresie bezpieczeństwa pożarowego poszukiwane są we wszystkich obszarach: prewencyjnych, ratowniczych oraz profilaktyki i edukacji społecznej. W obszarze działań prewencyjnych i organizacji ochrony przeciwpożarowej pożądane są przede wszystkim nowości w technicznych rozwiązaniach budowlanych, technicznych systemach zabezpieczeń przeciwpożarowych, które wykorzystywałyby inżynierię bezpieczeństwa pożarowego, a także wiedzę czerpaną z badań naukowych i praktyki.

Badania naukowe - w tym badania bezpieczeństwa, badania rozwojowe, współpraca i wynikające z niej wdrożenia - to aktualnie szanse i możliwości. Bezpieczeństwo i rozwój w tym otoczeniu są silniej jeszcze niż w przeszłości powiązane i zależne. Dlatego coraz większego znaczenia nabierają cytowane powyżej twierdzenia dotyczące ich wzajemnych zależności, gdzie bez bezpieczeństwa nie ma rozwoju, rozwój zaś ułatwia zapewnianie bezpieczeństwa.

24 Tamże.

25 J. Zboina, Bezpieczeństwo pożarowe, rozważania na gruncie nauki i praktyki, dz. cyt., s. 12. 


\section{Podsumowanie}

Nowe technologie stwarzają niedostępne wcześniej możliwości, są jednak także źródłem zagrożenia. Można je stosować w wielu obszarach, także w ochronie przeciwpożarowej, co zaprezentowano na przykładach przywołanych w niniejszej publikacji. Przybliżono także wybrane zagadnienia dotyczące możliwości i uwarunkowań koniecznych do wprowadzania nowych technologii i rozwiązań. Zagadnienia te powiązano z obecną i przyszłą rolą inżynierii bezpieczeństwa pożarowego, a także z zaufaniem do wyrobów, które wynika z ich oceny zgodności. Pośród przywoływanych rozwiązań i technologii można wyróżnić te:

- funkcjonujące od lat, sukcesywnie doskonalone i dostosowywane do zmieniających się potrzeb ochrony przeciwpożarowej,

- stosowane w niektórych państwach od dawna, w Polsce aktualnie wprowadzane do użytku ${ }^{26}$,

- nowe, które zaczynają być wykorzystywane w ratownictwie na całym świecie, ale które z uwagi na ich intensywny rozwój techniczny swoje pełne możliwości ujawnią prawdopodobnie dopiero w przyszłości.

Przedstawione przez autora przykłady i rozważania dotyczące możliwości wdrażania w ochronie przeciwpożarowej nowych technologii i rozwiązań oparte są na jego badaniach i doświadczeniach. Wieloletnia praktyka w ocenie zgodności wyrobów, opracowywaniu dla nich wymagań, programów certyfikacji, udział w pracach normalizacyjnych, a także projektach badawczych i rozwojowych były podstawą do przedstawionych poglądów i wniosków.

BSP to przykład nowej technologii, wciąż walidowanej i bardzo intensywnie się rozwijającej, która wykazuje wielki potencjał w połączeniu z innymi rozwiązaniami. Nie sposób nie zauważyć pewnych szans w jej wykorzystaniu w ratownictwie. Jak duża rola przypadnie w przyszłości BSP, to nadal jednak pytanie retoryczne. Bez wątpienia rozwiązanie to będzie wykorzystywane powszechniej niż obecnie nie tylko do wspierania i prowadzenia działań ratowniczych, ale i do działań prewencyjnych. Niewykluczone, że w niedługim czasie BSP w powiązaniu z innymi narzędziami będzie realizować nowe funkcje, również w ratownictwie. Dostrzec można również coraz więcej zastosowań dronów w obszarze ochrony środowiska i jej inżynierii²7. Przełomem dla takich rozwiązań może okazać się

26 Przy czym zastosowanie to jest w Polsce propozycją innych, nowatorskich rozwiązań zarówno w aspekcie technicznym, jak i organizacyjnym.

27 Przykładem może być wykorzystanie bezzałogowych statków powietrznych do wykrywania zanieczyszczeń i monitorowania jakości powietrza. 
chmura 5G, która pozwoliłaby na rozwój autonomii w masowym wykorzystaniu BSP. „Przedsiębiorstwa czekają z zapartym tchem na nadejście standardowych możliwości 5G, aby zaoferować nowe, zaawansowane, nowoczesne usługi”28. W stosunku do BSP tworzone są wymagania funkcjonalne, środowiskowe, użytkowe oraz wytyczne do stosowania w ratownictwie i prewencji pożarowej. Poszukuje się kolejnych innowacji. Jednym z przykładów prac łączących technologię BSP i monoookularu jest projekt nr DOB-BIO9/26/04/2018 Sterowanie autonomicznym dronem za pomoca gogli (monookularu). Podstawowe informacje o nim zawarto w załączniku 2.

28 „Internetowy świat jutra kusi możliwościami - inteligentnymi domami i miastami, autonomicznymi samochodami, sztuczną inteligencją i rzeczywistością rozszerzoną. Jest na co czekać. Pod technologiami rodem z filmów science-fiction, które zmieniają nasze codzienne życie, kryje się coś, co zupełnie je odmieni: 5G. Firmy nadrabiają zaległości, a operatorzy telekomunikacyjni liczą na wdrożenie tej technologii w 2020 roku. Można zrobić wiele, aby przygotować się na nową falę usług i na niej skorzystać. Przedsiębiorstwa czekają z zapartym tchem na nadejście standardowych możliwości 5G, aby zaoferować nowe, zaawansowane, nowoczesne usługi - możliwość pobierania treści wideo w ciągu kilku sekund, błyskawiczną obsługę wirtualnej rzeczywistości czy łączenie ze sobą wielu inteligentnych urządzeń. Rewolucyjne możliwości 5G nie tylko zwiększą przepustowość mobilnych usług szerokopasmowych. Wyjątkowo niezawodna sieć o niskich opóźnieniach umożliwi również powszechną komunikację między urządzeniami. W erze transformacji cyfrowej starsze infrastruktury informatyczne nie radzą sobie z obciążeniami obsługującymi duże ilości danych. Architekci i inżynierzy ds. sieci odegrają kluczową rolę we wprowadzaniu koniecznych zmian na potrzeby technologii 5G. Nie ma jednak powodu do obaw. Po pierwsze, chmura operatorów telekomunikacyjnych (Communications Service Provider, CoSP) zapewnia firmom elastyczność, skalowalność i responsywność dla całego łańcucha wartości, co ułatwia opracowywanie, uruchamianie i dostarczanie nowych usług w obliczu niespotykanych dotąd wymagań. Po drugie, przedstawiliśmy pięć prostych kroków, jakie firma powinna wykonać w celu wdrożenia chmury CoSP, aby być gotowa na technologię 5G”. Źródło: 5 Steps to a $5 G$-ready cloud [5 kroków do chmury 5G], strona internetowa Intel, https://www.intel.pl/content/www/pl/pl/it-managers/ 5-steps-to-a-5g-ready-cloud.html [dostęp: 22.06.2019]. 


\section{Bibliografia}

\section{Publikacje zwarte, opracowania naukowe}

1. Bąbik I., Bąk D., Jankowska K., Majka I., Standard CNBOP-PIB 0001:2019, Wprowadzenie do obrotu i użytkowania wyrobów stosowanych w ochronie przeciwpożarowej, Wyd. 6, Wydawnictwo CNBOP-PIB, Józefów 2019.

2. Bielicki P., Dowodzenie gaszeniem pożarów, ZW ZOSP RP, Gdańsk 2009.

3. Bielicki P., Podstawy taktyki gaszenia pożarów, SAPSP, Kraków 1996.

4. Brzezińska D., Strategie pożarowe - jak to wykorzystać w Polsce?, „Ochrona Przeciwpożarowa” 2017, 2.

5. Cempel C., Teoria i inżynieria systemów - zasady i zastosowania myślenia systemowego, Wydawnictwo Naukowe ITE PIB, Poznań 2008.

6. Corbett G., Fire Engineering's Handbook for Firefighter I \& II, Fire Engineering Books \& Videos, Tulsa 2007.

7. Corbett G., Fire Engineering's Skill Drills for Firefighter I and II, Fire Engineering Books \& Videos, Tulsa 2009.

8. Corbett G., Fire Engineering's Skill Drills for Firefighter I and II. Addendum Materials for 2012, Fire Engineering Books \& Videos, Tulsa 2012.

9. Cupryjak M., Czapewski T., Jasztal M., Przeciwdziałanie zagrożeniom i skutkom zamachów terrorystycznych w kontekście bezpieczeństwa Gazoportu w Świnoujściu, Wydawnictwo ZAPOL, Szczecin 2013.

10. Czupryński A., Bezpieczeństwo w ujęciu teoretycznym, w: Bezpieczeństwo, teoria, badania, praktyka, A. Czupryński, B. Wiśniewski, J. Zboina (red.), Wydawnictwo CNBOP-PIB, Józefów 2015.

11. Dworecki S.E., Logistyka w zarządzaniu bezpieczeństwem cywilnym (Wybrane zagadnienia), Wydawnictwo SGSP, Warszawa 2012.

12. Effron E., 8 kroków do wyższej efektywności, Wydawnictwo ICan Institute 2019.

13. Encyklopedia PWN, 2012.

14. Fehler W., O pojęciu bezpieczeństwa państwa, w: Bezpieczeństwo państw i narodów $w$ procesie integracji europejskiej, W. Śmiałek, J. Tymanowski (red.), Wydawnictwo Adam Marszałek, Toruń 2002.

15. Inżynieria bezpieczeństwa pożarowego oparta o cele funkcjonalne - Poradnik inżynierski SFPE, tłum. P. Tofiło, Stowarzyszenie Inżynierów Bezpieczeństwa Pożarowego, Warszawa 2007.

16. Kasprzak R., Fundusze Unijne, szansa dla małych i średnich przedsiębiorstw, Wydawnictwo Helion, Gliwice 2009. 


\section{Badania i wdrożenia | Bibliografia}

17. Kielin J., Bąk D., Projektowanie systemu ratowniczego - wstępny raport z badań, w: Ochrona przeciwpożarowa a bezpieczeństwo państwa, J. Zboina, B. Wiśniewski (red.), Wydawnictwo CNBOP-PIB, Józefów 2014.

18. Kiełbasa T., Zboina J., Gajownik D., Inżynieria bezpieczeństwa pożarowego, w: Ochrona przeciwpożarowa a bezpieczeństwo państwa, J. Zboina, B. Wiśniewski (red.), Wydawnictwo CNBOP-PIB, Józefów 2014.

19. Klapsa W., Suchecki S., Bąk D., Dziechciarz A., Czynniki narażenia podczas pożarów, w: Czerwona księga pożarów, t. 1, P. Guzewski, D. Wróblewski, D. Małozięć (red.), Wydawnictwo CNBOP-PIB, Józefów 2014.

20. Kolomny R., Hoff R., Firefighter Rescue \& Survival, PennWell Corporation, Tulsa, Oklahoma USA 2003.

21. Korycki S., System bezpieczeństwa Polski, AON, Warszawa 1994.

22. Kotarbiński T., Traktat o dobrej robocie, Wydawnictwo Polskiej Akademii Nauk, Wrocław 1982.

23. Koziej S., Bezpieczeństwo: istota, podstawowe kategorie i historyczna ewolucja, „Bezpieczeństwo Narodowe” 2011, 2.

24. Krauze A., Komputerowe modele rozprzestrzeniania się płomieni i gaszenia woda, w ocenie skutków rozwoju pożaru oraz skuteczności działania instalacji tryskaczowych, „Zeszyty Naukowe SGSP” 2019, 72(4).

25. Krueger A., System skutecznego wdrażania nowych technologii, prezentacja z XXVIII Forum Sprawozdawczo-Wyborcze Instytutów Badawczych, Warszawa, 27-28 maja 2019.

26. Lee T. H, Duckworth A. L., Zdetereminowana oragnizacja, "Harvard Business Review Polska” 2019, 194(4).

27. Leksykon terminów policyjnych, Kochańczyk. R., Mięsiak. P. (red.), Szkoła Policji w Katowicach, Katowice 2019.

28. Lipińska D., Podstawy inżynierii środowiska, Wydawnictwo Uniwersytetu Łódzkiego, Łódź 2016.

29. Łubek D., Konieczna K., Zmiana dzięki transparentności, „Harvard Business Review Polska” 2019, 194(4).

30. Marcinów, J. Zboina, G. Mroczko, Sprawdzone nowości, „Przegląd Pożarniczy” 2017, 12.

31. Martyniak M., Naucz się zarządzać swoimi emocjami, "Harvard Business Review Polska” 2019, 195(5).

32. Matusiak K. B., Budowa powiazań nauki i biznesu w gospodarce opartej na wiedzy, Rola i miejsce uniwersytetu $w$ procesach innowacyjnych, Oficyna Wydawnicza SGH, Warszawa 2010.

33. McCord P., Powerful, Jak zbudować kulturę wolności i odpowiedzialności, e-book, Wydawnictwo BeeBooks 2019. 


\section{Badania i wdrożenia | Bibliografia}

34. McGrail D. M., Firefighting Operations In High-Rise And Standpipe-Equipped Buildings, Fire Engineering Books \& Videos, Tulsa 2007.

35. Mizerski A., Definicje przygotowane przez zespół zadaniowy do spraw problematyki zakresów dyscyplin naukowych, określonych $w$ krajowym porządku prawnym, Rada Naukowo-Techniczna przy Ministrze Spraw Wewnętrznych, Warszawa 2013.

36. Moldoveanu M., Narayandas D., Przyszłość branży kształcenia liderów, „Harvard Business Review Polska” 2019, 194(4).

37. Motyl P., LABIRYNT sztuka podejmowania decyzji, Wydawnictwo ICan Institute 2018.

38. Olejnik A., Pihowicz W., Skomra A., Wydział Mechatroniki inżynieria bezpieczeństwa - nowa oferta dydaktyczna Wydziału Mechatroniki Wojskowej Akademii Technicznej, Wojskowa Akademia Techniczna, Warszawa 2008.

39. Osikowicz Ł., Szczerba K., Zasady bezpiecznej eksploatacji obiektów, Wydawnictwo CNBOP-PIB, Józefów 2012.

40. Pofit-Szczepańska M., Wybrane zagadnienia z fizykochemii wybuchu, Szkoła Główna Służby Pożarniczej, Warszawa 1996.

41. Racjonalizacja zarządzania jednolitymi formacjami umundurowanymi odpowiedzialnymi za bezpieczeństwo wewnętrzne, tom IV, Wiśniewski. B., Zwęgliński T. (red.), Wydawnictwo SGSP, Warszawa 2019.

42. Radkowski R. Zwęgliński T., Organizational aspects of the rescue system in Poland, w: Security and Law in the Cognitive and Utilitarian Context, Wiśniewski B., Kobes P., G. Sander (red.), Verlag Dr. Kovac GMBH Fachverlag für Wissenschaftliche Literatur, Hamburg 2015.

43. Sawicki T., Sygit B., Guzewski P., Problemy ustalania przyczyn pożarów - Istota przestępczego pożaru w świetle orzecznictwa sądowego. Zeszyt 2, Problemy Ustalania Przyczyn Pożarów, Polskie Towarzystwo Dochodzeń Popożarowych, Poznań 2013.

44. Security Threats - Law and Organization, B. Wiśniewski, G. Gerald, P. Kobes (red.), Verlag Dr. Kovac, Hamburg 2019.

45. Shapiro D., Negocjuj nienegocjowane, Wydawnictwo Ican Institute, Warszawa 2018.

46. Sienkiewicz P., Inżynieria systemów bezpieczeństwa, Polskie Wydawnictwo Ekonomiczne S.A., Warszawa 2015.

47. Stownik terminów z zakresu bezpieczeństwa narodowego, AON, Warszawa 2002.

48. Stachurska I., Szumowski F., Firma nadmiernie elastyczna, "Harvard Business Review Polska” 2019, 194(4).

49. Stańczyk J., Wspótczesne pojmowanie bezpieczeństwa, Instytut Studiów Politycznych PAN, Warszawa 1996.

50. Stowell F. M., Essentials of Fire Fighting and Fire Department Operations, Wyd. 6, Oklahoma State University, New Jersey 2013. 


\section{Badania i wdrożenia | Bibliografia}

51. Szczerba K., Bezpieczny dom, Wydawnictwo CNBOP PIB, Józefów 2012.

52. Trivesan E., Gorzeń W., Zinoecker R., Jak zrozumieć Klienta i na tym zarobić?, Wydawnictwo ICan Institute, Warszawa 2013.

53. Wiśniewski B., Bezpieczeństwo $w$ teorii $i$ badaniach naukowych, Wydawnictwo WSPoL, Szczytno 2011.

54. Wolanin J., Wybrane zagadnienia z podstaw rozwoju pożarów wewnętrznych, KG PSP, Warszawa 1985

55. Wycisk A., Płaszczyca M., Skuteczna wspótpraca nauka-biznes w opinii przedsiębiorców. Raport, Dział Badań i Analiz CZIiTT PW, Warszawa 2019.

56. Zaborowski J., Administracyjno-prawne ujęcie pojęć „,bezpieczeństwo publiczne” i porządek publiczny" (niektóre uwagi w świetle unormowań prawnych 1983-1984), „Zeszyty Naukowe ASW” 1985(41).

57. Zasady organizacji ratownictwa chemicznego i ekologicznego $w$ krajowym systemie ratowniczo-gaśniczym, KG PSP, Warszawa 2012.

58. Zboina J., Doskonalenie ochrony przeciwpożarowej jako warunek niezbędny zapewnienia bezpieczeństwa wewnętrznego Rzeczypospolitej Polskiej, rozprawa doktorska, AMW, Gdynia 2014.

59. Zboina J. , Kiełbasa T., Inżynieria bezpieczeństwa pożarowego, materiały z konferencji naukowej Ochrona Przeciwpożarowa w Systemie Bezpieczeństwa Państwa, Józefów 2013.

60. Zboina J., Bezpieczeństwo pożarowe, rozważania na gruncie nauki i praktyki, Wydawnictwo CNBOP-PIB, Józefów 2019.

61. Zboina J., Brudnicka K., Mroczko G., Bezpieczeństwo pożarowe obiektów budowlanych, w: Bezpieczeństwo na morzu lądzie i w powietrzu w XXI wieku, J. Zboina (red.), Wydawnictwo CNBOP-PIB, Józefów 2014.

62. Zboina J., Chmiel M., Kędzierska M., Gołaszewska M., Systemy wsparcia odbiorów i testowania wyrobów oraz rozwiazań na rzecz ochrony przeciwpożarowej, „Bezpieczeństwo i Technika Pożarnicza” 2015, 37(1).

63. Zboina J., Gancarczyk P., Certyfikacja usług w ochronie przeciwpożarowej w ujęciu praktycznym i teoretycznym, Wydawnictwo CNBOP-PIB, Józefów 2016.

64. Zboina J., Kielin J., Projektowanie systemu ratowniczego, Wydawnictwo CNBOP-PIB, Józefów 2015.

65. Zboina J., Mroczko G., Testowanie wyrobów innowacyjnych, „Przegląd Pożarniczy” 2015, 8.

66. Zboina J., Wspótpraca jednostek naukowych, w: Racjonalizacja oceny zgodności w ochronie przeciwpożarowej, t. 6 (w przygotowaniu do wydania), Wydawnictwo SGSP. 


\section{Badania i wdrożenia | Bibliografia}

67. Ziobro. J., Teoretyczne i praktyczne konteksty funkcjonowania ochotniczych straży pożarnych $w$ krajowych systemie ratowniczo-gaśniczym aspekty prawno-organizacyjne i geograficzno-przestrzenne Część 1, Warszawa 2019.

68. Zwęgliński T., Morgado C., Analitycal Approach to Cooperation Between Fire Brigade and the Police-Comparison Study on Base of Polish and Portuguese Experiences, "Internal Security” 2018, 10(1), DOI: 10.5604/01.3001.0012.7498.

\section{Akty prawne}

1. Rozporządzenie Parlamentu Europejskiego i Rady nr 305/2011 z dnia 9 marca 2011 r. ustanawiające zharmonizowane warunki wprowadzania do obrotu wyrobów budowlanych i uchylające dyrektywę Rady 89/106/EWG (Dz. Urz. UE 88 z 04.04.2011, s. 5-43).

2. Ustawa z dnia 24 sierpnia 1991 r. o ochronie przeciwpożarowej (tekst jedn.: Dz. U. 2020 poz. 961).

3. Ustawa z dnia 24 sierpnia 1991 r. o Państwowej Straży Pożarnej (tekst jedn.: Dz. U. 2020 poz. 1123).

4. Ustawa z dnia 30 sierpnia 2002 r. o systemie oceny zgodności (tekst jedn.: Dz. U. 2019 poz. 155).

5. Ustawa z dnia 16 kwietnia 2004 r. o wyrobach budowlanych (Dz. U. Nr 92 poz. 881 z późn. zm.) wraz z aktami wykonawczymi w formie rozporządzeń.

6. Rozporządzenie Ministra Infrastruktury z dnia 8 listopada 2004 r. w sprawie aprobat technicznych oraz jednostek organizacyjnych upoważnionych do ich wydawania (Dz. U. Nr 249 poz. 2497, nie obowiązuje).

7. Rozporządzenie Ministra Spraw Wewnętrznych i Administracji z dnia 20 czerwca 2007 r. w sprawie wykazu wyrobów służących zapewnieniu bezpieczeństwa publicznego lub ochronie zdrowia i życia oraz mienia, a także zasad wydawania dopuszczenia tych wyrobów do użytkowania (Dz. U. Nr 143, poz. 1002);

8. Rozporządzenie Ministra Infrastruktury i Budownictwa z dnia 17 listopada $2016 \mathrm{r}$. w sprawie krajowych ocen technicznych (Dz. U. 2016 poz. 1968 z poźn. zm.).

9. Rozporządzenie MSWiA z dnia 7 czerwca 2010 r. w sprawie ochrony przeciwpożarowej budynków, innych obiektów budowlanych i terenów (Dz. U. Nr 109, poz. 719).

10. Rozporządzenia MSWiA z dnia 18 lutego 2011 r. w sprawie szczegółowych zasad organizacji krajowego systemu ratowniczo-gaśniczego (Dz. U. Nr 46, poz. 239, nie obowiązuje).

11. Rozporządzenie MSWiA z dnia 3 lipca 2017 r. w sprawie szczegółowej organizacji krajowego systemu ratowniczo-gaśniczego (2017 poz. 1319). 


\section{Badania i wdrożenia | Bibliografia}

\section{Inne akta i dokumenty}

1. EN ISO/IEC 17000:2004 Ocena zgodności. Terminologia i zasady ogólne.

2. ISO 23932:2009 Fire safety engineering - General principles.

3. ISO/TR 13387-1:1999(E) Fire safety engineering - Part 1: Application of re performance concepts to design objectives, International Organization for Standardization, Geneve 1999.

4. NFPA 101: Life Safety Code, 2012 Edition, National Fire Protection Association 2011.

5. NFPA 1561 Standard on Emergency Services Incident Management System and Command Safety 2014 Edition, National Fire Protection Association 2014.

6. NFPA 1620 Standard for Pre-Incident Planning 2010 Edition, National Fire Protection Association 2011.

7. NFPA 1710 Standard for the Organization and Development of Fire Suppression Operations, and Special Operations to the Public by Career Fire Departments 2010 Edition, National Fire Protection Association 2009.

8. NFPA 1720 Standard for the Organization and Deployment of, Fire Suppression Operations, Emergency Medial Operations, and Special Operations to the Public by Volunteer Fire Departments, National Fire Protection Association 2013.

9. NFPA 5000: Building Construction and Safety Code, National Fire Protection Association, 2012.

\section{Zasoby internetowe}

1. 5 Steps to a 5G-ready cloud, Strona internetowa Intel, https://www.intel.pl/content/ www/pl/pl/it-managers/5-steps-to-a-5g-ready-cloud.html [dostęp: 22.06.2019].

2. Axtell P., Jak najlepiej zakończyć spotkanie?, portal internetowy Ican Institute, www. ican.pl [dostęp: 20.02.2020].

3. Chcieć, móc, potrafić: Dlaczego ludzie nie robia tego, co powinni? Niezbędnik menedżera, https://hrnews.pl/chciec-moc-potrafic-dlaczego-ludzie-nie-robia-tego-co-powinni-niezbednik-menedzera/ [dostęp: 1.02.2020].

4. Elite Leadership Program 2020, strona internetowa Ican Institute, https://elp.hbrp.pl/?utm_ medium=email\&utm_source=getresponse\&utm_campaign=ELP [dostęp: 25.02.2020].

5. Informacje podstawowe o PN, strona internetowa Polskiego Komitetu Normalizacyjnego, www.pkn.pl/informacje-podstawowe-o-pn [dostęp: 13.02.2020].

6. Internetowa encyklopedia PWN, www.encyklopedia.pwn.pl [dostęp: 13.02.2020].

7. Kawecka-Zygadło B., BIM - technologia parametrycznego modelowania informacji o budynku, https://www.muratorplus.pl/technika/programy/bim-innowacyjna-technologia-parametrycznego-modelowania-informacji-o-budynku-aa-h4hz-msdd-YXYr.html [dostęp: 03.02.2020]. 


\section{Badania i wdrożenia | Bibliografia}

8. Krakowski A., Most między nauka a biznesem, portal internetowy Ican Institute, 2018, https://www.ican.pl/a/most-miedzy-nauka-a-biznesem/DdCGfxvco, [dostęp: 8.03.2020].

10. Platforma Aplikacji Przeciwpożarowych, https://pap24.pl/o-platformie/cele/ [dostęp: 1.02.2020].

11. Raport badawczy, Współpraca korporacji ze startupami, Czy korporacje w Polsce sa realnie gotowe na wspótpracę ze startupami?, Huge Thing 2019, http://hugething.vc/report/ [dostęp: 28.02.2020].

12. Rubin J., Jak wprowadzać przełomowe innowacje?, portal internetowy Ican Institute, https://www.ican.pl [dostęp: 20.02.2020].

13. Schmidt W., Internet rzeczy to przewaga w każdej branży, portal internetowy Ican Institute, https://www.ican.pl/a/internet-rzeczy-to-przewaga-w-kazdej-branzy/7MaSgj41 [dostęp: 20.02.2020].

14. Społeczne oblicze innowacji. Jak wspierać postawy innowacyjne i promować etos innowatora?, J. Górski, A. Mikołajczyk, M. Tataj (red.), Fundacja Polskiego Godła Promocyjnego, Warszawa 2016, https://mli.org.pl/upload/files/Raport_MLI_ebook2.pdf [dostęp: 8.03.2020].

15. Strona internetowa Biblioteki Głównej AGH, www.bg.agh.edu.pl [dostęp: 13.02.2020].

16. Strona internetowa Ministerstwa Gospodarki, www.mg.gov.pl [dostęp: 13.02.2020].

18. Strona internetowa Polskiego Komitetu Normalizacyjnego, www.pkn.pl/normy-zharmonizowane [dostęp: 13.02.2020].

19. Strona MIT Sloan Management Review (MIT SMR), sloanreview.mit.edu [dostęp: 25.02.2020].

20. Wawak S., O Zarządzaniu, http://wawak.pl/pl/content/ciagle-doskonalenie [dostęp: 12.11.2013].

20. Zmienia się prawo budowlane. Ma być prościej i szybciej, https://www.slaskibiznes.pl/wiadomosci,zmienia-sie-prawo-budowlane-ma-byc-prosciej-i-szybciej,wia5-1-2481.html [dostęp: 03.02.2020]. 


\section{Nota o autorze}

st. bryg. dr inż. Jacek Zboina - pełni służbę w Centrum Naukowo-Badawczym Ochrony Przeciwpożarowej im. Józefa Tuliszkowskiego - Państwowym Instytucie Badawczym w Polsce na stanowisku zastępcy dyrektora ds. certyfikacji i dopuszczeń. Do obszaru prowadzonych badań naukowych i pracy zawodowej autora należą: bezpieczeństwo, ochrona przeciwpożarowa, techniczne systemy zabezpieczeń przeciwpożarowych oraz ocena zgodności. Absolwent studiów inżynierskich i magisterskich w Szkole Głównej Służby Pożarniczej, ukończył również studia podyplomowe, kierunek Menadżer Innowacji, w Szkole Głównej Handlowej w Warszawie. Stopień naukowy doktora nauk społecznych w zakresie nauk o bezpieczeństwie uzyskał w Akademii Marynarki Wojennej w Gdyni na Wydziale Dowodzenia i Operacji Morskich. Absolwent rocznego programu MANAGMENT 2016 w ICAN Institute. Oficer PSP. Rzeczoznawca Komendanta Głównego PSP ds. zabezpieczeń przeciwpożarowych.

senior brig. Jacek Zboina, Ph.D. - serves in the Scientific and Research Center for Fire Protection - National Research Institute as a Deputy Director for Certification and Admittance. The area of his scientific research and professional work includes: safety, fire protection, technical fire protection systems and conformity assessment. He graduated from engineering and master degree studies at the Main School of Fire Service; he also completed post-graduate studies at the faculty Innovation Manager at the Warsaw School of Economics. He obtained his Ph.D. in the field of safety sciences at the Naval Academy in Gdynia, at the Department of Command and Maritime Operations. He is a graduate of a one-year management development program MANAGMENT 2016 in ICAN Institute. He is a State Fire Service officer and fire protection expert to the Chief Commandant of the State Fire Service. 


\section{Załącznik 1}

\section{Zintegrowany system kwalifikacji w ochronie przeciwpożarowej}

\section{Zintegrowany System Kwalifikacji (ZSK)}

Rozwiązanie systemowe, które oferuje możliwość formalnego potwierdzenia umiejętności i wiedzy zdobytych w trakcie samodzielnego uczenia się oraz zapewnia powszechny dostęp do uporządkowanej listy obecnych na rynku kwalifikacji z ich jasno określonym opisem. Pełna lista kwalifikacji funkcjonujących w ramach ZSK znajduje się w publicznej bazie danych - Zintegrowanym Rejestrze Kwalifikacji (ZRK). Dobrze opisane kwalifikacje podpowiedzą, jaki zakres wiedzy i umiejętności musi posiadać osoba, która chce potwierdzić swoje kompetencje w danej dziedzinie lub czego pracodawca może oczekiwać od kandydatów na stanowiska w swojej firmie.

\section{kwalifikacja}

Zestaw efektów uczenia się w zakresie wiedzy, umiejętności oraz kompetencji społecznych, nabytych w edukacji formalnej, edukacji pozaformalnej lub poprzez uczenie się nieformalne, zgodnych z ustalonymi dla danej kwalifikacji wymaganiami, których osiągnięcie zostało sprawdzone w walidacji oraz formalnie potwierdzone przez uprawniony podmiot certyfikujący. W skrócie: kwalifikacja to określony zestaw efektów uczenia się - zgodnych z ustalonymi standardami - których osiągnięcie zostało formalnie potwierdzone przez upoważnioną instytucję.

W kontekście ZSK określenia „kwalifikacja” nie można używać zamiennie z takimi terminami jak: „zawód”, „uprawnienie zawodowe”, „prawo wykonywania zawodu”, „kompetencje zawodowe”, „kompetencje” itp.

\section{walidacja}

Sprawdzenie, czy osoba ubiegająca się o nadanie określonej kwalifikacji (niezależnie od sposobu uczenia się tej osoby), osiągnęła wyodrębnioną część lub całość efektów uczenia się wymaganych dla tej kwalifikacji. Walidacja jest procesem wielowymiarowym i wieloetapowym, obejmującym identyfikowanie, dokumentowanie i weryfikację efektów uczenia się określonej osoby. Identyfikowanie i dokumentowanie są szczególnie ważne w przypadku osób, które uczyły się, nie 
korzystając ze zorganizowanych form kształcenia. Dla wiarygodności walidacji konieczne jest wskazanie jasnych kryteriów weryfikacji, dostosowanych do charakteru efektów uczenia się.

\section{certyfikowanie}

Proces, w wyniku którego osoba ubiegająca się o nadanie określonej kwalifikacji, po uzyskaniu pozytywnego wyniku walidacji, otrzymuje od uprawnionego podmiotu certyfikującego dokument potwierdzający nadanie określonej kwalifikacji. Proces certyfikowania jest realizowany zgodnie z ustaloną procedurą. W przypadku niektórych kwalifikacji uzyskiwanych poza systemami oświaty i szkolnictwa wyższego walidacja i certyfikowanie są zadaniami różnych podmiotów (np. egzamin na prawo jazdy przeprowadza wojewódzki ośrodek ruchu drogowego, a certyfikuje, tj. wydaje dokument, starosta powiatu).

\section{minister właściwy}

Minister określony w przepisach ustawy z dnia 4 września 1997 r. o działach administracji rządowej.

\section{instytucja certyfikująca (IC)}

Podmiot, który uzyskał uprawnienia do certyfikowania. W kontekście ZSK instytucja certyfikująca oznacza podmiot posiadający uprawnienia do nadawania określonych kwalifikacji włączonych do ZSK. Nie wszystkie kwalifikacje muszą być włączone do ZSK, dlatego w szerszym kontekście określenie „instytucja certyfikująca” oznacza podmiot, który nadaje jakieś kwalifikacje.

\section{podmiot zewnętrznego zapewniania jakości (PZZJ)}

W kontekście ZSK podmiotem zewnętrznego zapewniania jakości jest instytucja, której minister właściwy powierzył funkcję zewnętrznego zapewniania jakości wobec instytucji certyfikującej. PZZJ zajmuje się wsparciem instytucji certyfikujących w odpowiednim prowadzeniu działań związanych z walidacją i certyfikowaniem. Prowadzi ciągły monitoring działań IC oraz okresową ewaluację zewnętrzną tych działań. 


\section{Zintegrowany System Kwalifikacji}

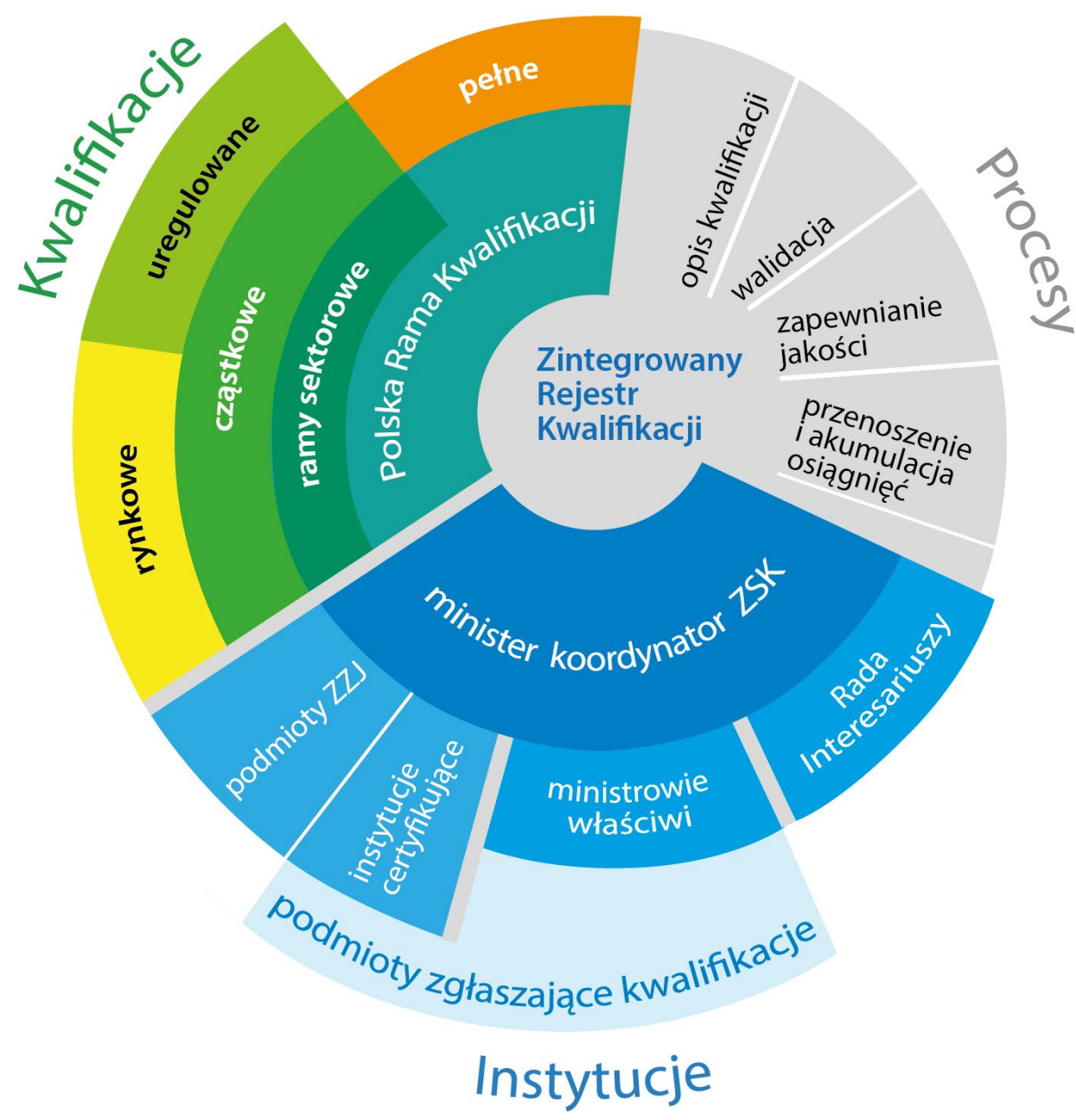

Ryc. 1. Zintegrowany system kwalifikacji

Źródło: Materiały upowszechniające Instytutu Badań Edukacyjnych. 


\section{Załącznik 1 | Zintegrowany System Kwalifikacji w ochronie przeciwpożarowej}

\section{Polska Rama Kwalifikacji}

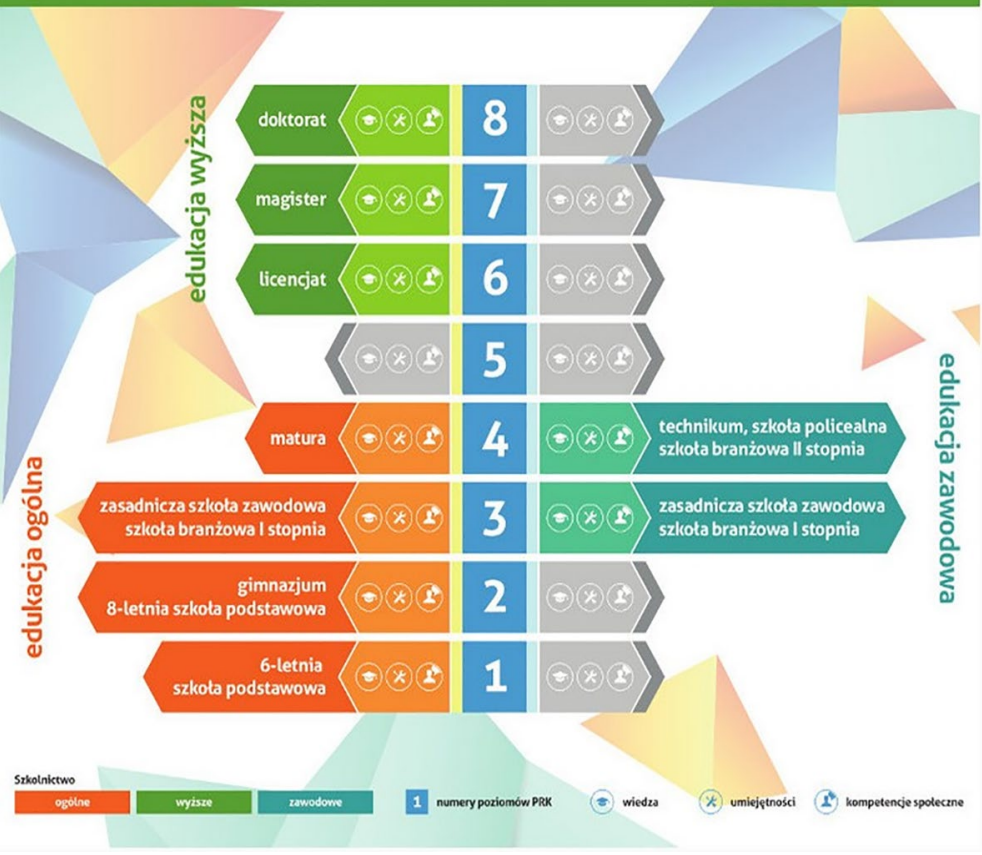

Ryc. 2. Polskie ramy kwalifikacji

Źródło: Materiały upowszechniające Instytutu Badań Edukacyjnych.

Centrum Naukowo-Badawcze Ochrony Przeciwpożarowej - PIB we współpracy z Instytutem Badań Edukacyjnych opisało następujące kwalifikacje rynkowe:

1. Projektowanie zabezpieczeń przeciwpożarowych - stałe urządzenia gaśnicze gazowe (SUG-G).

2. Montaż i konserwacja zabezpieczeń przeciwpożarowych - stałe urządzenia gaśnicze gazowe (SUG-G).

3. Projektowanie zabezpieczeń przeciwpożarowych - dźwiękowe systemy ostrzegawcze (DSO).

4. Montaż i konserwacja zabezpieczeń przeciwpożarowych - dźwiękowe systemy ostrzegawcze (DSO).

5. Projektowanie zabezpieczeń przeciwpożarowych - systemy sygnalizacji pożarowej (SSP) i sterowania urządzeniami przeciwpożarowymi. 
6. Montaż i konserwacja zabezpieczeń przeciwpożarowych - systemy sygnalizacji pożarowej (SSP) i sterowania urządzeniami przeciwpożarowymi.

7. Montaż i konserwacja autonomicznych czujek: tlenku węgla, dymu, ciepła i gazu.

8. Ratownictwo lotniskowe - wykonywanie działań ratowniczych realizowanych przez lotniskowe służby ratowniczo-gaśnicze (LSR-G).

Szczegółowe informacje dotyczące Zintegrowanego Systemu Kwalifikacji dostępne na stronie: https://www.kwalifikacje.gov.pl/.

Decyzją MSWiA z dnia 9 lipca 2019 r. Centrum Naukowo-Badawcze Ochrony Przeciwpożarowej im. Józefa Tuliszkowskiego Państwowy Instytut Badawczy otrzymało uprawnienia do certyfikowania następujących kwalifikacji rynkowych: 1. Projektowanie zabezpieczeń przeciwpożarowych - dźwiękowe systemy ostrzegawcze (DSO).

2. Projektowanie zabezpieczeń przeciwpożarowych - systemy sygnalizacji pożarowej (SSP) i sterowania urządzeniami przeciwpożarowymi.

3. Projektowanie zabezpieczeń przeciwpożarowych - stałe urządzenia gaśnicze gazowe (SUG-G).

4. Montaż i konserwacja zabezpieczeń przeciwpożarowych - dźwiękowe systemy ostrzegawcze (DSO).

5. Montaż i konserwacja zabezpieczeń przeciwpożarowych - systemy sygnalizacji pożarowej (SSP) i sterowania urządzeniami przeciwpożarowymi;

6. Montaż i konserwacja zabezpieczeń przeciwpożarowych - stałe urządzenia gaśnicze gazowe (SUG-G).

7. Montaż i konserwacja autonomicznych czujek: tlenku węgla, dymu, ciepła i gazu.

Obwieszczenie w sprawie włączenia do ZSK kwalifikacji rynkowych dotyczących projektowania, montażu i konserwacji zabezpieczeń przeciwpożarowych oraz montażu i konserwacji autonomicznych czujek tlenku węgla, dymu, ciepła i gazu dostępne jest pod adresem: http://monitorpolski.gov.pl/MP/2019/446. 


\section{Załącznik 2}

\section{Podstawowe informacje o projekcie nr DOB-BI09/26/04/2018 Sterowanie autonomicznym dronem za pomoca gogli (monookularu)}

Projekt pt. Sterowanie autonomicznym dronem za pomoca gogli (monookularu), numer umowy projektu: DOB-BIO9/26/04/2018 realizowany jest przez konsorcjum naukowe tj. SIMPRO Sp. z o. o. (lider), Centrum Naukowo-Badawcze Ochrony Przeciwpożarowej im. Józefa Tuliszkowskiego - Państwowy Instytut Badawczy (partner) ze środków finansowych Narodowego Centrum Badań i Rozwoju (konkurs nr 9/2018 NCBR na wykonanie projektów w zakresie badań naukowych lub prac rozwojowych na rzecz obronności i bezpieczeństwa państwa).

Lata realizacji: 2018-2021.
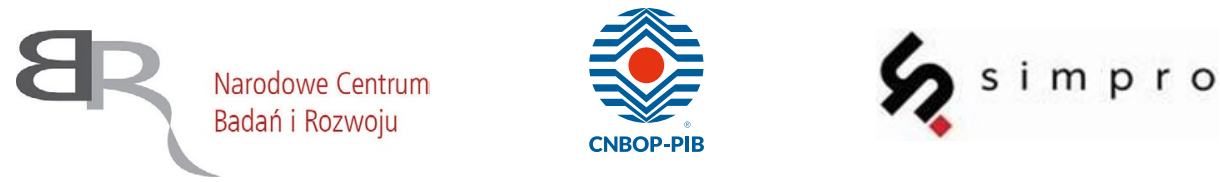

Efektem projektu zgodnie z oczekiwaniami gestora będzie opracowanie i wykonanie systemu sterowania bezzałogowym statkiem powietrznym (BSP). Rozwiązanie to będzie posiadało możliwość sterowania BSP za pomocą wzroku operatora zgodnie z obecnymi możliwościami technologicznymi, a także przejęcia kontroli nad autonomicznym lotem BSP. Wartością dodaną, dzięki know-how konsorcjantów, będą:

- narzędzie szkoleniowe wraz ze scenariuszami,

- narzędzie do wstępnej selekcji operatorów pod względem ich predyspozycji i odporności na chorobę symulatorową,

- testy sterowania BSP pod kątem oddziaływań psychofizycznych na operatora,

- badania nad sterowaniem BSP dot. pracy w określonych warunkach środowiskowych, mające na celu zapewnienie niezbędnej niezawodności i funkcjonalności urządzenia w otoczeniu, w którym będzie ono wykorzystywane.

Proponowane rozwiązanie znacząco ułatwi obsługę BSP, a także pozwoli na wdrożenie nowych funkcjonalności i możliwości operacyjnych sprzętu. 
